\title{
FINAL REPORT ON A CALCULATIONAL PARAMETER STUDY OF SOILS TYPICAL OF SOME ESSEX I CRATERING STTES
}

Mliton F. Goodrich

Jon B. Bzyan.

Jeffrey $k$. Thonsen

Charles M. SnelI

Harch 15,1976

Prepared for U.S. Energy Rowaveh \& Development

Administration under contiuct No. W-7405-Eng-48

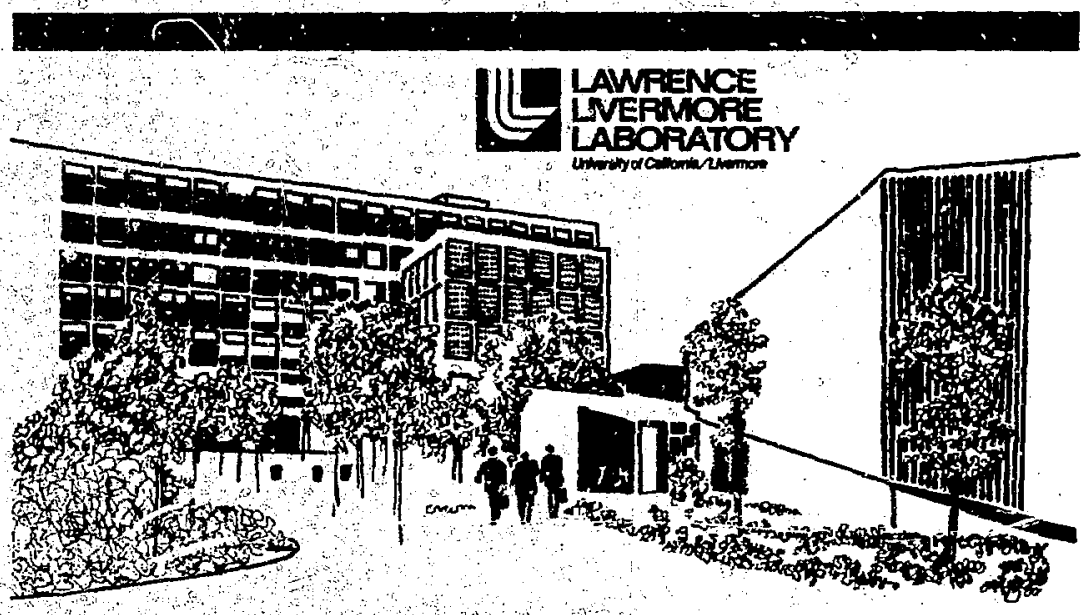




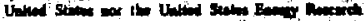

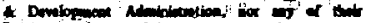

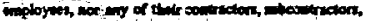

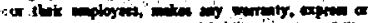

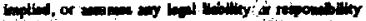

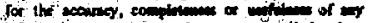

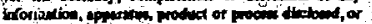

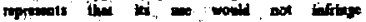

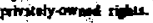

\section{HOTKE}

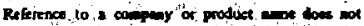

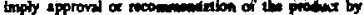

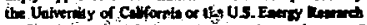

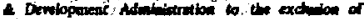
others the mas bo ande.

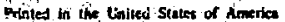
Avaiuble Imo

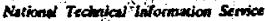

US. Deppariment of Commorió

5285 Fort Roya Rond

Springrield, VA 2216I

Pilas: Prinjed Copys ; Mistorine 52.25

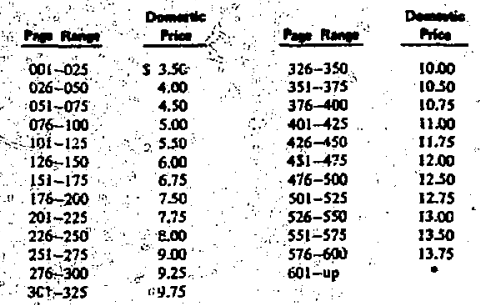

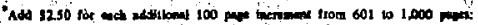

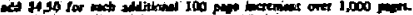




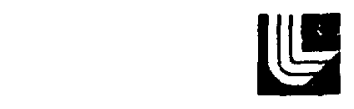

LAWRENCE LNERMORE LABORATORY

Unversifyol Cartorna Lnermore.Cationa 94550

UCR:-52038 (WES TR-:-7-76-4)

\title{
FINAL REPORT ON A CALCULATIONAL PARAMETER STUDY OF SOILS TYPICAL OF SOME ESSEX I CRATERING SITES
}

\author{
Milton F. Goodrichth \\ Jon B. Bryan \\ Jeffrey 4 . T!romsen \\ Charles M. Snell
}

MS. date: March 15, 1,6

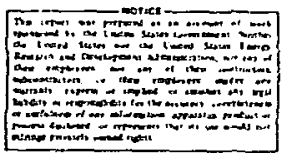

rivork sponsored ty office of Chlef of Engineers undar $R$ \& D Project $4 A 362719 A T 40$, for the Explosive Excavation Division of the hieapons Eflects Laboratory. U. S. Ariny Englneer Waterways Experiment Station, Vicksiurg. Mississippi.

"HPrasert address: Kaiser Englneers, Energy Sources Division, 300 Lakeside Drlve, Oakland, CA. 


\section{Contents}

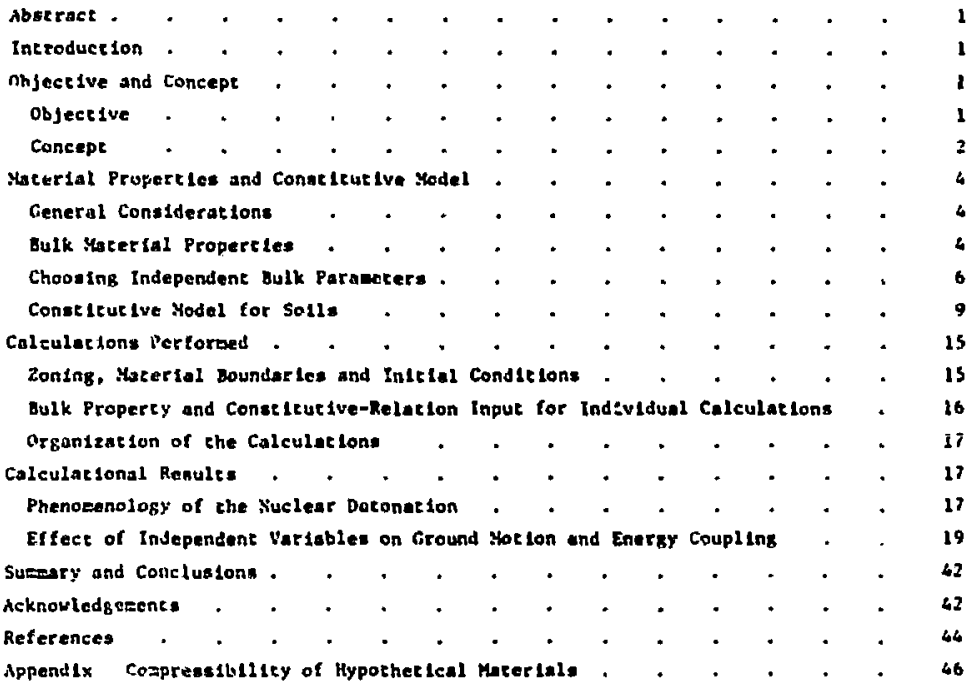




\title{
FINAL REPORT ON A CALCULATHONAL PARAMETER \\ STUDY OF SOLLS TYPKAL OF SOME ESSEX I CRATERING GTTES
}

\begin{abstract}
Abetract
The one-dimensional computer caleulaclons deccribed in this report vere performed to afmulate screas-urve propagation and kinetic energy transfer associated with subsurface cratering deconations in solls. A hypotherical 20-ton-yield nuclear explosive was assumed as the energy source, surzounded by a single soll material. varlous coll deacriptions vere selocted in

order to systematically scudy the renge of soll reaponse to the auclear detonation. The colle were representative of the layered alxtures of sand and clay found at the ESSEX high-explonive cratering oltes neer Ft. Polk, Louleiand. Soll propertiea analyzed in this study include water saturation, bulk deakity, fallure eavelope, and low-preasure bulk aodulue.
\end{abstract}

\section{Introduction}

The Earth Sciences (K) Division of the Laurence Liverwore Laborstory (LLL) has con'icted a caleulational parameter study for $1:$ : Explosive Excavation Division " of the bupong Effects Laboratory of che U.S. Aray Engincer Haterways Experiment Station. The seudy began a cystematic Investigacion Inco the influence of soll properties on nuclear cratering and ground motion.

Hork performed during the study included Invert tgating the static properties of colls, deteratning the ralevant range of values of those properties to be uned in the study, devaloping a conse icursve relaclone sodel that could derive representative dyaalc prejarties frow given static properties for hypothetical solle spanning the ranges of interest in the study, and calculating the reaponse of axch hypothetIcal soil to auelear detonation in one disension.

This repor: review the work performed, with tiphesil on the resules of the celculations. For sone coplcs, wre detalled inforeacion can be found in the two progrese reports. 1,2

\section{Objective and Concept}

\section{OBJECTIVE}

The salculacional paraneter atudy deucribed here 19 part of a long-rango

Formerly known as the Explosive Excavation Resesich Laboratory (EERL) of the U.S. Atry Englueer Waterwsye Exper Lent Statinn (WES); located et LLL, LLveraore, California. parasecer study proposed by the Explosive Excavat ion Division. ${ }^{3}$ The overall objecclve of this study is to exaniae the phenomenology of auclear crateriog and to present the results in a form ditectly usable in an inproved U.S. Aray fieid handbook predicting various effects of 

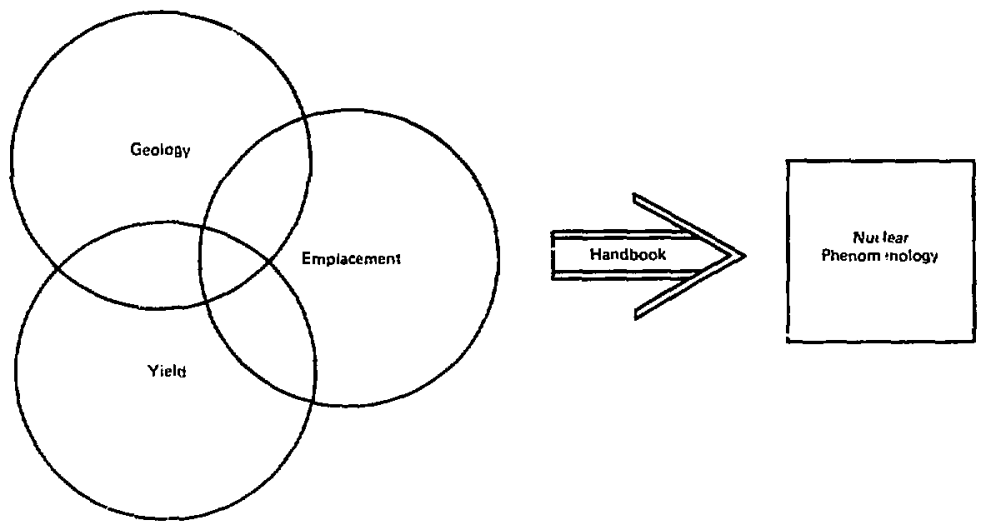

Fir. 1. Concept of total nuclear affects study. The study will produce information for a handbook that will predict nuclear phenowerology given the geology, yield, and emplacement.

nuclear weapons. Generally these effects

are influenced by the ofte genlogy, the explosive yieid, and the emplacement ( 1 e., both the conflguration and the septh of burial). The effects of greatest interest are ground motion, cratizr size, and ancillary cratering-related ef fects. The concept of the total study is shown schematically in Fig. 1.

A complete Investigation into the effects of site geology alone requires more work char is entalled In this year's calculational parameter study. Thus it is onl; a beginning step coward accomplishment of the long-range objectives of the study and is not expected to answer all questions about cratering effects. The priary goal of this year's atudy was to ideatify the caterial properztes that have greacest Influence on energy coupling and stresswave propagat ion resulting from a burled nuclear detonation.
CONCEPT

The concept of the calculational parameter study ia shown schematically in Fig. 2. Material propertieg were separated Into two groups: bulk (or Inftial) properties and constitut ive relations. Bulk properties relate to the undisturbed soll only, whereas constituilve relations describe the effects of pressure on the material. A comprehenstve (although not exhaustive) list of bulk properties was compllea. kelation. shipg between these properties were derived, and a set of Independent varlables was chosen.

Since thts is a followon scudy designed to clarify and expand the results of the etght: ESSEX I* cratering teats, conducted In the Peason Ridge area of Fort Polk,

"ESSHX 18 an acronym formed from effects of gubgurface expjosions. 


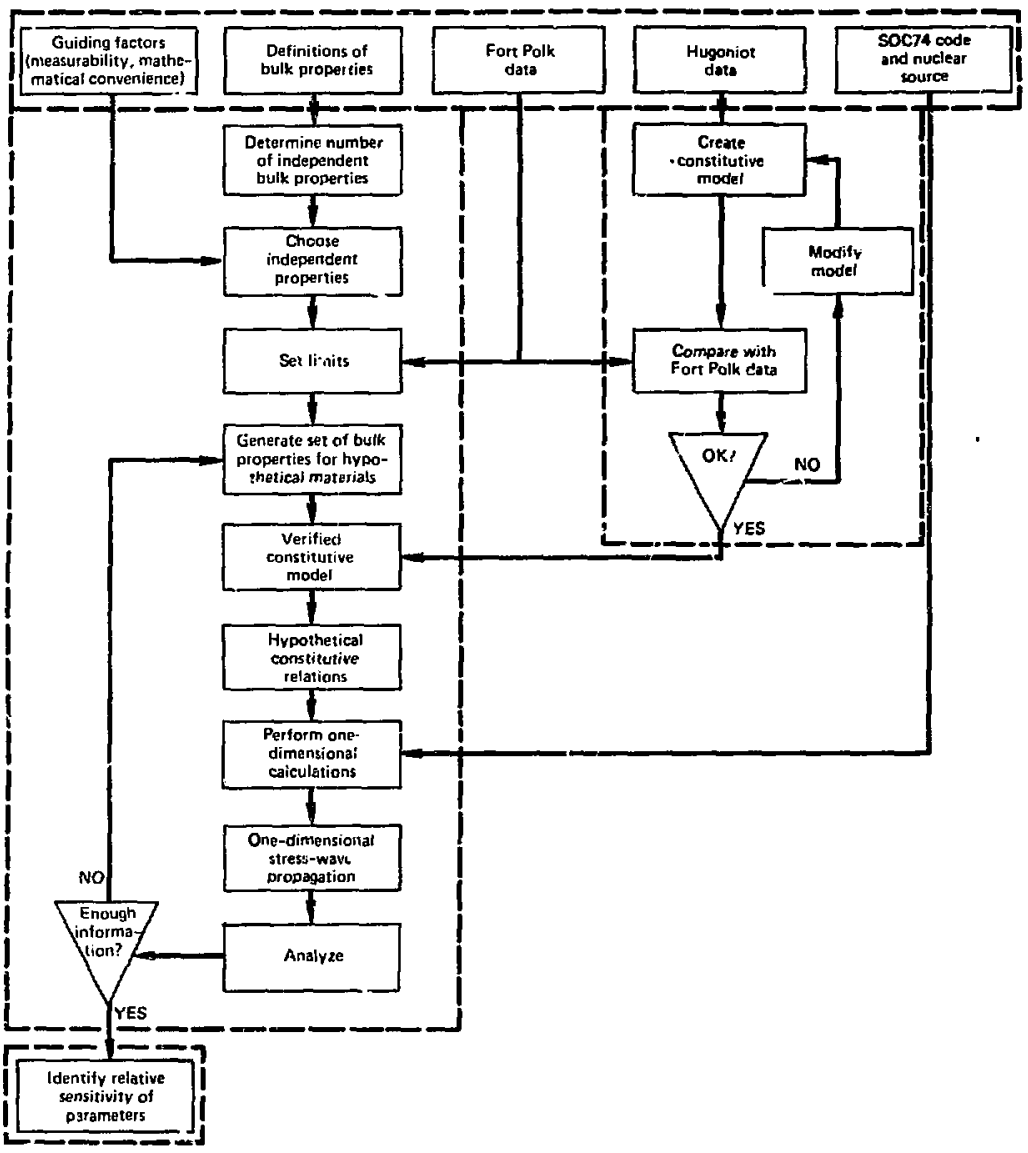

F1g. 2, The geologic parameter study concept. 
Louselana, ${ }^{4,5}$ the study was 1 lmited to solls characteristic of that Bite. The solls and Pavements Laboratory (S \& PL) of WES conducted, for ESSEX, an extensive Investigation of the solls at that cest site. The Investigation produced 13 IdealLzed untes with macerial properties cypical of subsurface materials ensountered at the elght locations studied. ${ }^{6}$ These units were exawined and used to infer approprlate limits for the study's Independent variables.

. Sirce a knowledge of the constitutive relabions was reeded in order to caiculate the effect of a nuclear detonation in a given material, a model was developed to cupply representative constiturive relations given the values of the Independent bulk propertles. The model's applicability was established by comparing model-generated constitutive celatic is for the 13 For: Polk units with those recommended by $S$ \& PL (based on laboratory cests). The nodel was then ueed to develop constitutive relations for hypoth-tical solls with bulk propertjes spanning the ranges proposed for the study.
One-dimensional, spherical code calculatlons were performed for each hyporhetical sol1 by means of the SOC74 code, which is a time-dzpendent, Lagrangian, finitedifference computer code $\mathrm{c}^{7-10}$ that can simulate stress-wave propagation through solid materials with feneralized characteristics.

Strr.ss wave prop'gation away from the nuslear source ar: energy coupling into the soil were calculated as a function of tree. The results vere plotted, analyzed, and compared with other calculational results. Sensitivity of the results to Individual bulk propertieg could then be In:estigated systematically.

The generel method became one of performing calculatsons on hyporhetical materials, and varying the Independent bulk paraneters within the set limits. Whet the results proyed sensitive to a particular parameter, more calculations were pertformed using adótional values of that bylk property within the ilaiting range. This process was continued until adequate curves could be drawn showing the sensitivity of the calculational results to that bulk property.

\section{Material Properties and Constitutive Model}

GENERAL CONSTUERATIONS

In this stud. material properties have been conslderfa under two caregorles: bulk properties ard constitutive relations. Bulk proper:-1es are static characteristics of the material in 1 ts undisturbed stace (Initial condition) only, whereas constitutive rejations define the effects of pressur $\dot{e}$ on the matertala.
BULK MATERIAL PROPERTIES

A review of bulk parameters, which quentitatively relace information about bulk propertles, was perfortred for the purpose of defining independent parameters. A comprehensive but not ex? haupitive list of bulk parameters was complled and is shown in Table 1. Mathemacical relationships between these parameters were derlved 
Table 1. Definition of bulk materlal parametera.

\begin{tabular}{|c|c|c|c|}
\hline Parameters & $\begin{array}{l}\text { Symbol used } \\
\text { in atudy }\end{array}$ & $\begin{array}{l}\text { ASTM } \\
\text { symbol }\end{array}$ & Description \\
\hline \multicolumn{4}{|c|}{ Composition porameters } \\
\hline \multirow[t]{4}{*}{ Densittes } & $\rho_{0}$ & $\gamma_{0}$ & Bulk density (sample mass/sample volume) \\
\hline & $\rho_{y}$ & $Y_{\mathbf{d}}$ & Dry denstty (mass of solids/sample volume) \\
\hline & $P_{w}$ & $\gamma_{w}$ & $\begin{array}{l}\text { Muss of water per unit total volume (water mass) } \\
\text { sample vo:ume) }\end{array}$ \\
\hline & $\rho_{g}$ & $G_{s}$ & Grein density (mass of solids/volume of solids) \\
\hline \multirow[t]{6}{*}{ Volumes } & e & e & Yold racto (volume of volds/voluse of sollas) \\
\hline & $e_{w}$ & -- & Water ratio (valume of water/volume of solids) \\
\hline & $\phi_{0}$ & - & Total porosity (volume of volds/sample valume) \\
\hline & $\phi_{a}$ & $v_{\mathbf{a}}$ & Afr-filled porosity (air volume/sample volume) \\
\hline & $\phi_{4}$ & $v_{w}$ & Wacer-filled porosity (wacer vilume/sample volume) \\
\hline & *a & $v_{s}$ & Sol1d volume (volume of solids/sample volurs) \\
\hline \multirow[t]{2}{*}{ Saturations } & $s_{w}$ & $s$ & Water saturation (water volume/volume of volds) \\
\hline & $\mathbf{s}_{\mathbf{e}}$ & -- & Air saturacion (a1r volume/volume of volds) \\
\hline \multirow[t]{9}{*}{ Weights } & $w$ & $W$ & Wats:r content (we1ght of water/dry we1zht of sampie) \\
\hline & \multicolumn{3}{|r|}{ Elascic parameters } \\
\hline & $\mathbf{K}$ & & Bulk moc'ulus \\
\hline & $\mathbf{6}$ & & Shear modulus \\
\hline & $\cdot v$ & & Potsson's ratto \\
\hline & $\lambda$ & & Lamé elastic parameter \\
\hline & $\mathbf{E}$ & & Young's wodulus \\
\hline & B & & Constrained modulus \\
\hline & $\mathbf{k}_{0}$ & & Stress ratio in uniaxial strain \\
\hline
\end{tabular}

Three independent paramecers.

b Two Independent parameters.

and are given in Table 2. These parameters fall naturally Into two groups: composition parameters and elastic parameiers. Exemination of the relationships berween each group's members indicates a totil of five
Independent bulk parameters. Of linese five Independent parameters, three must be composition and two elastis. Composit1on parameters chosen as Independert wust Incluce one density and one volume ratio, 
Table 2. Macheratical relationshipa among paraseters.

Composition parameters (using $\rho_{g}, \rho_{0}$, and $S_{W}$ as a base)

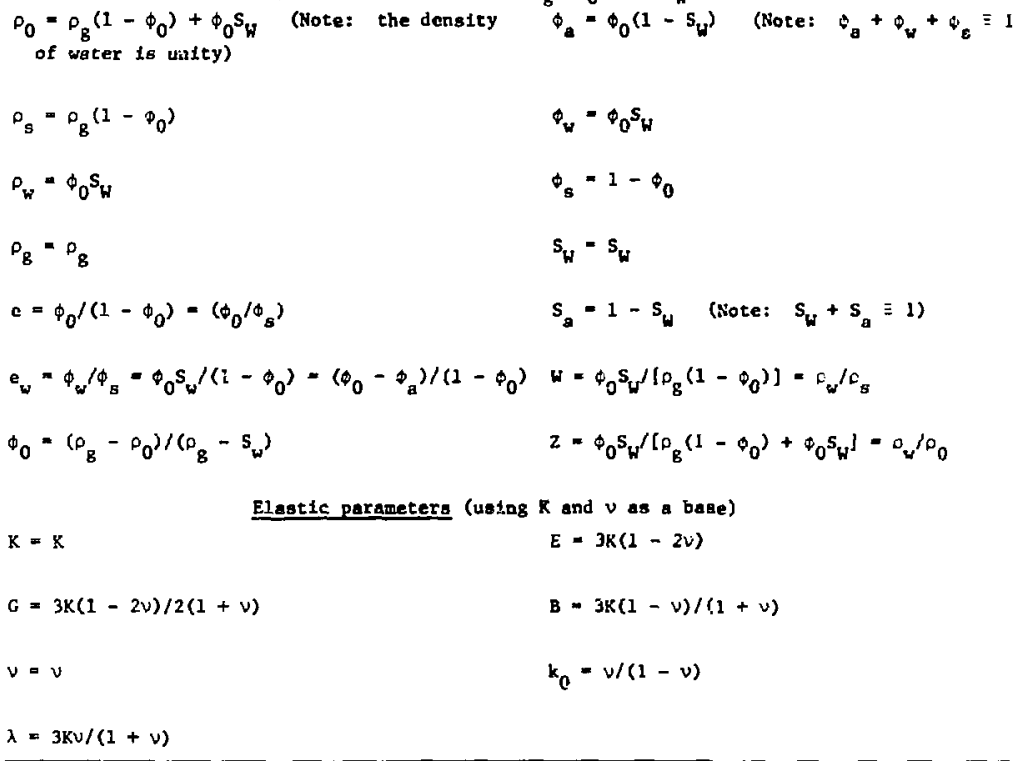

or saturation. The remaining composition parameter and the two Independent elastic paraneters can then be selected from their respective grcups, at the investigator's sonvenience.

Since the gtudy was Ifmited to materfals typ1ca) of Fort Polk, the value of each bulk parameter was calculated for a11 13 Fort Polk untts. These are shown tn Table 3; the ranges for each of these parameters will be discussed in the next bact1od. Values of the elastis parameters, other than the bulk modulus $\mathrm{K}$ and the 'fmiting value of Polseon's ratio $v$, are dot shown.

\section{CHOOSING IRDEPENDENT BULK PARAMETERS}

The three composition parameters cuusc.. as Independent during the study were grain Jensity $p_{g}$, bulk densicy $p_{0}$, and wacer sacuratzon $S_{w}$. These were chosen primartly for prsctical reasons. Grain density can be assumed to be constant $\left(o_{\mathrm{B}}=2.67 \mathrm{Mg} / \mathrm{m}^{3}\right)$, since it shows only a slight variation ar Furt Polk (2.66 to $2.70 \mathrm{Mg} / \mathrm{m}^{3}$, see Table 3 ). It was felt that bulk density would be more easily measured under field conditions than most other parameters. Water sacuration $S_{w}$ was uned because previous exper:lence on rocks Indicates that this factor has a strong influence on both 
Table 3. Materlal propertics frod the 13 fort Polk unita.

\begin{tabular}{|c|c|c|c|c|c|c|c|c|c|c|c|c|c|c|c|c|c|c|}
\hline Ente & $\begin{array}{l}\text { Clay } \\
(2)\end{array}$ & $\begin{array}{l}\text { Sent } \\
(x)\end{array}$ & $\begin{array}{c}{ }_{0} \\
\left(\mathrm{H}_{\mathrm{B}} / \mathrm{m}^{3}\right) \\
\end{array}$ & $\left(M_{B} / F^{3}\right)$ & $\left(2 \mathrm{~s} / \mathrm{m}^{3}\right)$ & $\left(r_{0} / p^{3}\right)$ & 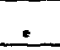 & ev & 0 & 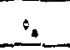 & u & $t_{n}$ & 5 & s. & 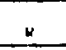 & 2 & $\begin{array}{l}\text { Inftie) } \\
\mathrm{R} \text { (CFA) } \\
\end{array}$ & $\begin{array}{r}\text { InItel } \\
\end{array}$ \\
\hline 1 & 23 & 75 & 1.039 & 1.6160 & 0.3230 & 2,66 & 0.646 & 0.332 & 0.1923 & 0.0690 & 0.3210 & 0.6075 & 0.823 & 0.17 & 0.1999 & 0.167 & 0.172 & 0.30 \\
\hline 2 & 33 & 65 & 1.843 & 1.4153 & .4253 & 2.64 & 0.876 & 0.799 & (6b71 & .0420 & .4235 & .3329 & 0.911 & .06 & .3002 & ס & 1.036 & .31 \\
\hline i & is & 65 & 1.793 & 1.3350 & .6600 & $2+62$ & 1.000 & 0.920 & .5000 & .0400 & .2600 & .5000 & 0.920 & .38 & .3646 & .258 & 1.352 & .33 \\
\hline 4 & 40 & 60 & 1,163 & 1.2611 & .5212 & 2.70 & 1.136 & 1.133 & .3401 & .0250 & $.3 \times 12$ & .4397 & 0.963 & .03 & .4197 & $.20 s$ & 0.021 & .33 \\
\hline 5 & $s$ & 95 & 1.981 & 1.6026 & - J6:2 & 2.88 & 0.535 & 0.638 & .3375 & .0130 & .1844 & .6035 & 0.767 & .03 & .2398 & .296 & 1.793 & .28 \\
\hline 6 & 3 & 43 & 1.947 & 15976 & . 3984 & 2.64 & 0.665 & 0.665 & .3944 & .0030 & .1996 & .6006 & 1.00 & .00 & .2500 & .200 & 5.172 & .48 \\
\hline 7 & 5 & 93 & 1.065 & 1.5766 & .3784 & 2.67 & 0.603 & 0,641 & .4093 & .0110 & .3186 & .3903 & 0.924 & $.0 t$ & .2600 & . [9] & 1.138 & .30 \\
\hline ค & is & bs & $\therefore \mathrm{H} 4 \mathrm{O}$ & 1.3812 & .6738 & 2.68 & $0.9 \mathrm{~s}^{2}$ & 0.913 & .4824 & , Olvi & .6718 & .5176 & 0.918 & .02 & .1601 & $.25]$ & $2.2 \mathrm{J4}$ & .33 \\
\hline 9 & 3 & is & 2.019 & 1.6566 & .3666 & 2.67 & 0.616 & 0,388 & .3203 & N::00 & . A4 &.$b 191$ & 0.938 & Sis & .22134 & .180 & 3.059 & .20 \\
\hline 10 & 40 & 60 & 1.843 & 1.1530 & .4880 & $2.6 \mathrm{~g}$ & 0,976 & 0.465 & .6944 & .0065 & .6890 & .5056 & 0.981 & .01 & .1601 & .264 & 3.945 & .18 \\
\hline $1 i$ & 40 & 60 & 1.746 & $1,20 \mathrm{st}$ & .5118 & 2.70 & 1,136 & 1.216 & .5318 &, 0000 & .5318 & .4502 & 1.000 & .00 & .6201 & .296 & 4.682 & .48 \\
\hline 12 & is & as & 1,973 & 1.4751 & .0431 & 2,67 & d.609 & 0.800 & .6673 & $.000 t$ & .4013 & .3387 & 1.000 & .00 & .3011 & .213 & 5.013 & .48 \\
\hline 13 & 35 & bs & $1.8 \mathrm{Ls}$ & 1.3913 & 0.6796 & $2, b)$ & 0.15 & +.000 & 0,4230 & $0,0 \times 33$ & 0.6136 & 0.3211 & 0.989 & 0.01 & n.3404 & 0.253 & 7.31 & 020 \\
\hline
\end{tabular}


s,round motion and craterjing in the range of Interest $(0.9$ to 1.0$) .11,12$

Bulk modulus $K$ and Polsson's ratio $v$ were chosen as the Independent elastic parameters. Bulk modulus was chosen because it can be estimated from a measurement of the speed of sound if the intelal shear modulus is small enougin to be neglected. Polsson's ratio increases very rapidly with conflning pressure : : very low pressures $(-.01 \mathrm{GPa}$ ) from 1 ts Inttial value, shown for each unit in Table 3, to a value of 0.46 to 0.48 (very close to the lioiting value at ingh pressures of 0.5 ) for almost all Fort Polk units. Hence, Instead of usin the range of Initial values of $v$ from the Fort Poik deta, a censtant value, 0.48 , was used.

Therefore two of the five Independent parameters were held conscant, wh1le three were varled. Linfts of variation for these three vartables were chosen so as to completely cover thelr rangee at Fort Polk. Table 4 lists the values of the two independent bulk parameters held constant and the ranges of values of the remaining three.

By using the values of the independent composition parameters $\left(\rho_{g}, \rho_{0}\right.$, and $\left.s_{w}\right)$

Table 4. Range of values of the five independent bulk parameters considered in the study

Independent bulk parameters held constant

Grain density $\rho_{g}: 2.67 \mathrm{Mg} / \mathrm{m}^{3}$

PoLason's ratio v: 0.48

\section{Independer.t bulk paraweters varied}

Bulk densicy $P_{0}: 1.7$ to $2.1 \mathrm{Mg} / \mathrm{m}^{3}$

Water seturation $5 ; 0.8$ to 1.0

In1t1al bulk mod: $:$ g: 2.5 to $7.5 \mathrm{GPa}$ shown In Table 4, the ranges of each dependent composition parameter exhibited by the 13 Fort Polk units axe spanned x'se than adequately. This is shown in Table 5, which compares the ranges of the depandent composition parameters calculated from Table 4 with the ranges obtained directly frow Table 3, Not only the 1Imits but also the distribution of the Fort Polk data within those limits is important for the study. Figure 3 shows this diatribution by plotting $\rho_{0}$ versus $s_{w}$ for the 13 Fort Polk units. The data are randomly acattered within an envelope approximately

Table 5. Ranges for the dependent composition parameters.

\begin{tabular}{|c|c|c|}
\hline $\begin{array}{l}\text { Composition } \\
\text { parameter }\end{array}$ & $\begin{array}{c}\text { Range } \\
\text { Calculated } \\
\text { from Table } 4\end{array}$ & $\begin{array}{l}\text { Range frcm } 13 \\
\text { Fort Polk un1ts } \\
\text { (Tuble 3) }\end{array}$ \\
\hline$\rho_{5}\left(\mathrm{Mg} / \mathrm{m}^{3}\right)$ & $1.12-1.86$ & $1.2417-1.6546$ \\
\hline$\rho_{w}\left(M_{g} / \mathrm{m}^{3}\right)$ & $0.24-0.58$ & $0.3230-0.5318$ \\
\hline e & - & $0.6137-1.1744$ \\
\hline$\phi_{0}$ & $0.30-0.58$ & $0.3803-0.5401$ \\
\hline$\phi_{a}$ & $0.0-0.12$ & $0.0-0.069$ \\
\hline$\phi_{w}$ & $0.24-0.58$ & $0.3230-0.5318$ \\
\hline $\mathbf{e}_{\mathbf{w}}$ & & $0.5317-1.136$ \\
\hline$\Phi_{\mathrm{g}}$ & $0.42-0.70$ & $0.4599-0.6197$ \\
\hline $\mathbf{s}_{\mathbf{a}}$ & $0.0-0.20$ & $0.0-0.17$ \\
\hline$y$ & -- & $0.1999-0.4207$ \\
\hline$z$ & $0.11-0.34$ & $0.167-0.296$ \\
\hline
\end{tabular}


1 inited by a $\rho_{0}$ range from 1.75 to 2.05 and an $s_{w}$ range of 0.9 to 1.0 , excluding only unit 1. The parameter study covers a somewhat larger area, with $\rho_{0}$ ranging from 1.7 to 2.1 and $S_{w}$ ranging from 0.8 to 1.0 . This was done to engure complete coverage of the dependent vartables over the1: respective ranges at Fort Polk and account for the possibility that the composition of all materials at the site might exhibit a wider variation than that deternined fror the 13 idealized units.

For the elastlc parameters, the range of values of Initial bulk modulue (2.5 to $7.5 \mathrm{GPa}$ ) does not span the entfie range of values found in the Fort Polk data $(0.172$ to $7.31 \mathrm{GPa}$ ), as seen from Table 3 . Experience has shown that the effect of the elastic parameters on nuclear cratering and close-in ground motion ( 3 to $15 \mathrm{~m}$ for an 84-GJ nuclear detonation) was minuscule. A few calculations were performed at different values of $K$ to prove this point, and no further analygis of the remainder of the elastic parameters ohown in Table 1 was performed.

CONSTITUTIVE MODEL FOR SOILS

A constitutive model was developed to provide constitutive relations for hypothetical solis having bulk properties in the ranges digcussed in the preceding section. This model consists of trio parts: a computer mode1 that predicts compressibility and an impirical model that gives failure information. This section discusses briefiy each of these models. More detalled information is presented in a previous progress report. ${ }^{2}$

Since the $50 \mathrm{C} 74$ computer code was used for the calculationg, the model was con-

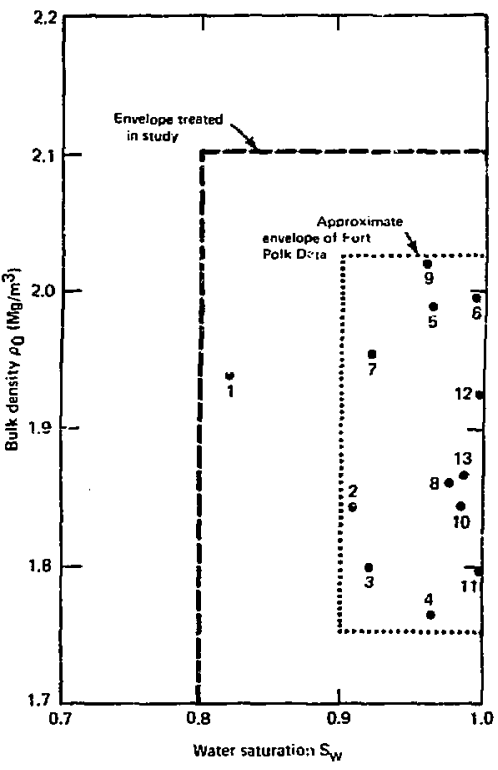

Ffg. 3. Distribution of Fort Polk units in $\mathrm{Po}_{\mathrm{O}}^{-\mathrm{S}}$ space. The number beside unte number.

structed so as to output constitutive relations compatible with that code. The soc74 code provides for a great deal of flexibility in the modeling of material behavior. Regimes of response that can be modeled include linear elastlc or Incrementally elastic compression hysteretic compaction, hrittle fallure, ductile flow (elastic-plastic fallure) tensile fallure, liquefaction or vaporization of a solld, vaporization of only the water component in a solid, and gaseous behavior. Techniques are avallable to simulate certain types of rate-dependent 
behavior. Since ingufficlent data are avallable to charecter1ze rate-dependent effects in the soils being conaldered, the constitutive relations for all hypothet1cal soils used in the study were assmued to be rate-1r-apendent. The models used in the sac74 code also aseune that waterlals are lsotropic and homogeneous.

The soc74 code uges tabular stressstrain relationships to spectfy the respone of solid media under hydrostatic cimpression. The user enters the tables, which give the pressure $P$ as a function of the excess compression $\mu\left(\mu=\rho / \rho_{0}-1\right.$, where $P_{0}$ is the initial density of the matertal and $\rho$ is 1 ts density at the pressure P). The general form of the relation expected by the code is shown in Fig. 4 . Two curves are required for each thaterial: a "virgin Ioading" curve and a "completely

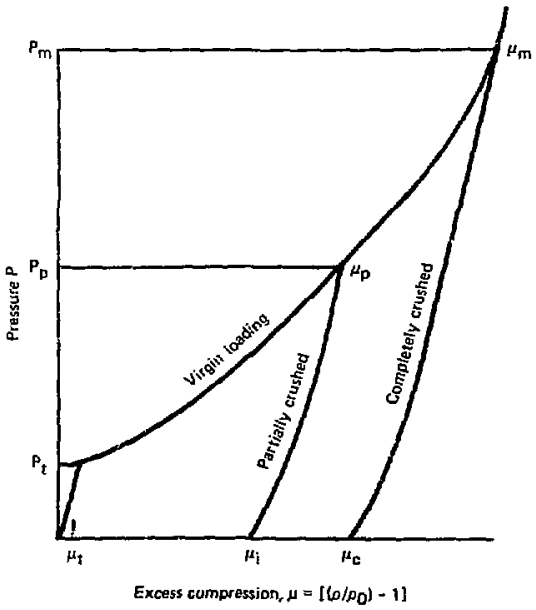

Fig. 4. General form of the compressibility curve for the Soc74 code.

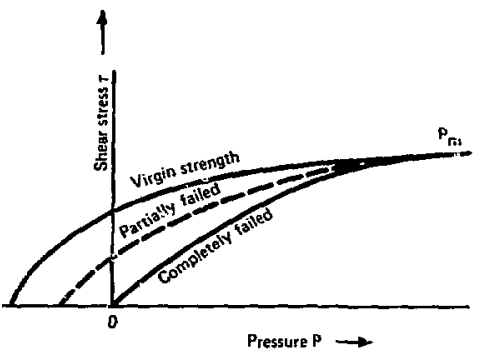

Fig. 5. General form of the faliure curve for the Soc74 code.

crushed" unloading (and reloading) curve. The virgin loading curve is assumed to be reverstbly elastic until the transtition pressure $P_{t}$ Is exceeded; onc. exceeded, irreverstble compaction (hysteretic behav1or) is allowed. The loacing and unloading curves are assumed to therge inco a single curve at and above a specified terge pressure $P_{\text {D }^{*}}$ All alr vold space is assumed to be irreversibly removed on loading between $P_{E}$ and $P_{m}$. Partial compaction is allowed on loading to a maximum pressure between $P_{t}$ and $P_{m}$. No further hysteretic compaction is allowed $\mathrm{Gt}$ pressures above $P_{\text {In }}$.

The fallure criterion in socis is represanted by a table glving permiasible shear stress $t$ versus confining pressure $P$. This specification linits the deviaturic atress (shear stress) that a materiai can support. Brttcle fallure and strengrh reduction may be simulated by specifylng two atrength curves for a materlal: a "virgIn" curve and a "completely fajled" curve. The material strength is gradually reduced from the virgin curve to the completely falled curve as damage to the 
materfal increases, The general form of the relation expected by 50074 is show In FIg. 5 .

\section{Compresg1b111ty Model}

The sot.1-compresstbility model is an extention of the model developed by Butkovich ${ }^{13}$ for certaln rock types. Input numbers for the couputer model are shown in Table 6. Three of the first four input tumbers, $p_{0}, s_{w}$, and $k$, wil be recognized as the Independent bulk parameters chosen for variation in the study (see Table 4).

Values for $P_{T}$ and $P_{\text {I }}$ are dependent somewhat on the fallu? " model usod; Input for these quantities is discussed in the section that follows, Finally, the weight fractions of clay and sand must be provided so thet proper weighting of the loading Hugontots of sand and clay can be cciputed, as discussed in zef. 2. There welght fractions were held constant (2CLA 0.25 and $2 S I L=0.75)$ in thr r.udy.

The model appears to be quite adequate for predicting compressibility for solls typical of Fort Polk. In a recent proggress report, ${ }^{2}$ compreasibility curves generated using the bulk properties of the

Table 6. Input required for sot1-compressIbIlity model

\begin{tabular}{|c|c|}
\hline \multicolumn{2}{|c|}{ Symbol } \\
\hline$\rho_{0}$ & Intial bulk density $\left(\mathrm{Mg}_{\mathrm{g}} \mathrm{m}^{3}\right)$ \\
\hline $0_{8}$ & Grain density $\left(2.67 \mathrm{Mg} / \mathrm{m}^{3}\right)$ \\
\hline$s_{w}^{\circ}$ & Wacer saturation \\
\hline $\mathrm{K}$ & Initlal bulk modulus $[\mathrm{GPa} \times 100$ (Mbar) \\
\hline $\mathbf{P}_{\mathrm{T}}$ & Transition pressure $[\mathrm{GPa} \times 100$ (Mbar)] \\
\hline$P_{M}$ & Merge pressure $[\mathrm{GPa} \times 100(\mathrm{Mbar})]$ \\
\hline ZCLA & Height fraction of clay $(0.25)$ \\
\hline ZSIL & Wetghe fraction ef sand $(0.75)$ \\
\hline
\end{tabular}

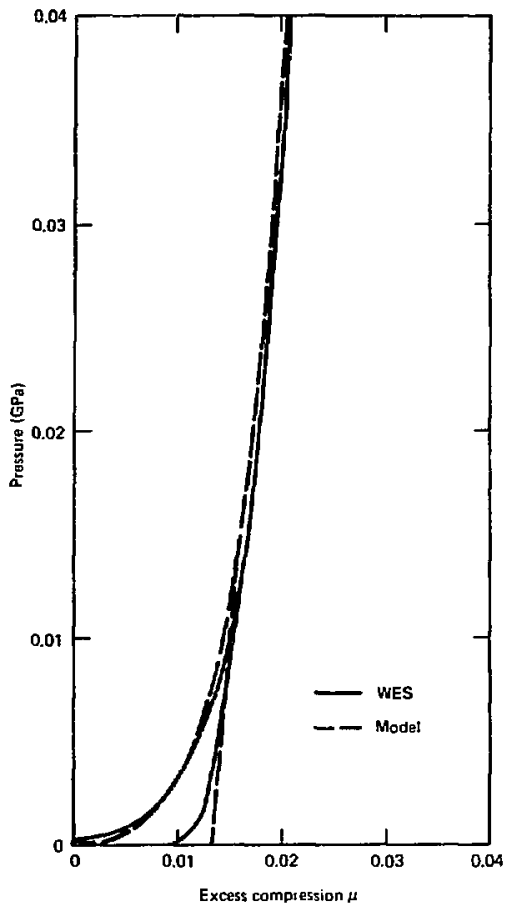

F18. 6. Comparison of the model-generated compressibility curve using the bulk propertieg of Port Polk unit 5 soil with the WES-recommended curve.

13 Fort Polk units (see Table 3) were compared to the WES-recommended curves ( $S \&$ PL), which vers sased on laboratory tests. For almost ail units, adequate agreement was observed. Figure 6 shows th1s comparison at low pressures (0 to $0.04 \mathrm{GPa}$ ) for unte 5. This untt layer was recommended at or near shot depth on several of the ESSEX I high-explosive experiments, 6 
Fa1lure Model and Strength Parameters

As discussed eartier in this section, SOC74 requires a faflure curve of the rorm shown In FIg. $j$. Moreover, the compressibility model requires the input of two strength parameters, $P_{M}$ and $P_{T^{*}}$ So far three Independent bulk parameters have been chosen for variation. If In addition the fallure curve and $P_{M}$ and $P_{T}$ were also Independently varted, the number of Independent variables in the study would become prohtbitively large. This section discusses how the fallure curves for the hypothetical soils were chosen and how $P_{M}$ and $P_{T}$ were tied to those curves, thereby reducing the numbur of independent variables from six to four.

II the progress report ${ }^{2}$ an at tempt was made to correlate the measured maximum shear strengths of the Fort Polk solls with their bulk properties, in particular, water content. Such a correlation was found by Butkovich ${ }^{13}$ to exist for some rock t:pes. However, the results found for Fort Polk solls vere inconclusive.

In order to establish approxinate fallure criterfa for the hypothetical solls, then, an empirical rodel was developed. This was based on the wES-recommended fa11ure curves for the 13 Fort Polk un $1 \mathrm{tg}^{6}$ and for an additional unfi, valt $14 .^{14} \mathrm{Th} / \mathrm{s}$ latter was identified by $S$ \& PL as a "weak rock," having strength characteristics exceeding those of the other 13 units. These units were divided inco four groups: uncemented-saturated (un:ts 6, 11, and 12), uncemented-unsaturated (untts $1,2,4, j$, 7,8 , and 10), cemented-unsaturated (units 9 and 13), and weak rock (unit 14). Maximum and minimum typical (or fitted) curves were then drawn for each of the four groups. These sets of typical curves were then used as another Independent variable.

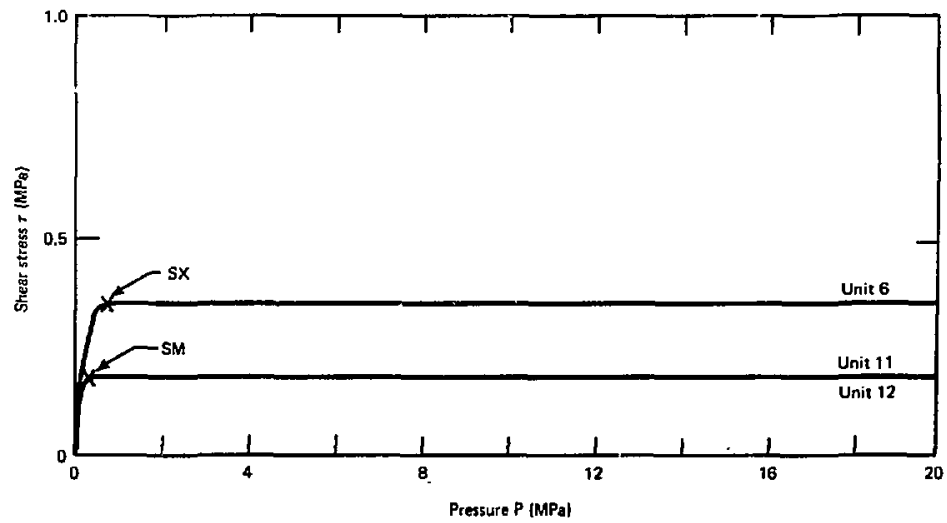

F1g. 7. Fallure curves for uncemented-saturated s.11s (SM and SX). 


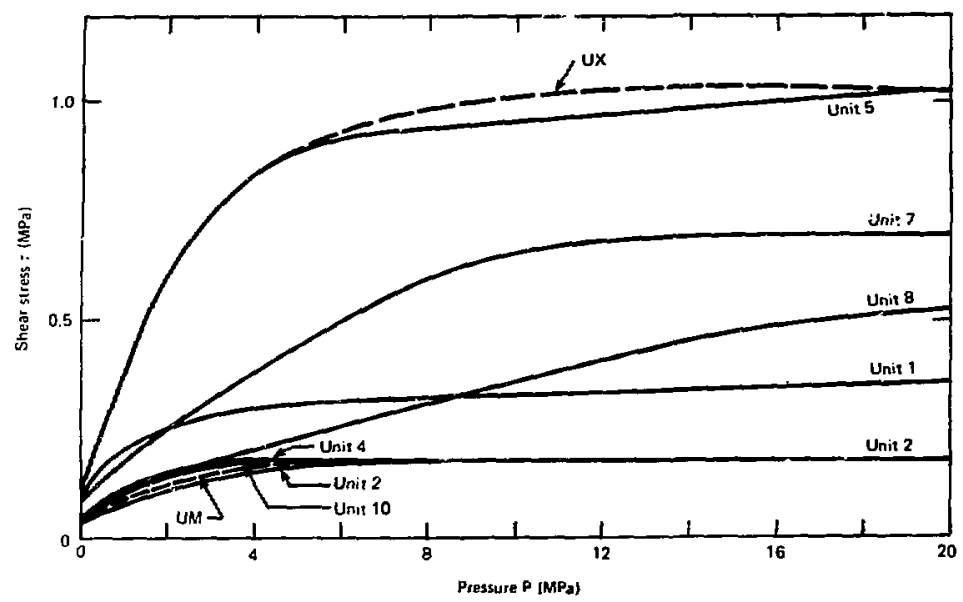

F1g. B. Fallure curves for uncenenced-unsaturated so1ls (UM and UX).

Typical curves for the uncementedsaturated group (SM and SX) are shown in Fig. 7, In chts case they correspond to the actual maximum and minimum curves recomended by WES. Fig. 8 shows typtcal curves for the uncemented-ungaturated group (UM and UX). They also correspond closely with the maximum and minicaum curves recomended by WES. The unsaturaredcemented (CM and $\mathrm{CX}$ ) curves, st Fig. 9 shoss, do not follow the data as closely. In particulax, the flateau or step that appears in the data for unit 9 uas not included in the $\mathrm{CX}$ curve. This vas because chis region is not reached on initial load1ng. Ulse of a conscant Polseon's ratio does not allow fallure to occur below $P_{M^{2}}$. Since the atep behavior 10 thoughe to te assoclated with pore collapae, it should not be present during unloading af ter loadIng to higher pressures. Thus the samo curve, CX, was used for both loading and unloading. Finally, Figure 10 shows th: typical curves for weak rack (RM and $\mathrm{RX}$ ). The $P X$ curve follows the undt 14 curve closely. The IN curve was chosen so as to have a maximus ahear strength $\tau_{x}$ exactly half thet of the RX curve, $10 \mathrm{MPa}$.

For the study, the merge pressure $P_{M}$ was chosen to te a function of che maximum shear strength $\tau_{x}$. Figure 11 shous $F_{y}$ versus $I_{x}$ for che unsaturated Fore Polk units. The values show considerable. scatcer. Hence, somewhat arbitrarily, $P_{S}$ (in megapascils) vas related Ifnearly co $T_{x}$;

$$
P_{H} \equiv 5 \tau_{x}+9.5 \text {. }
$$

This line falls in the aiddle of the data shown In Fig. 11 and hence to representative of Fort Palk sofis.

The transition pressures $P_{T}$ wore the 


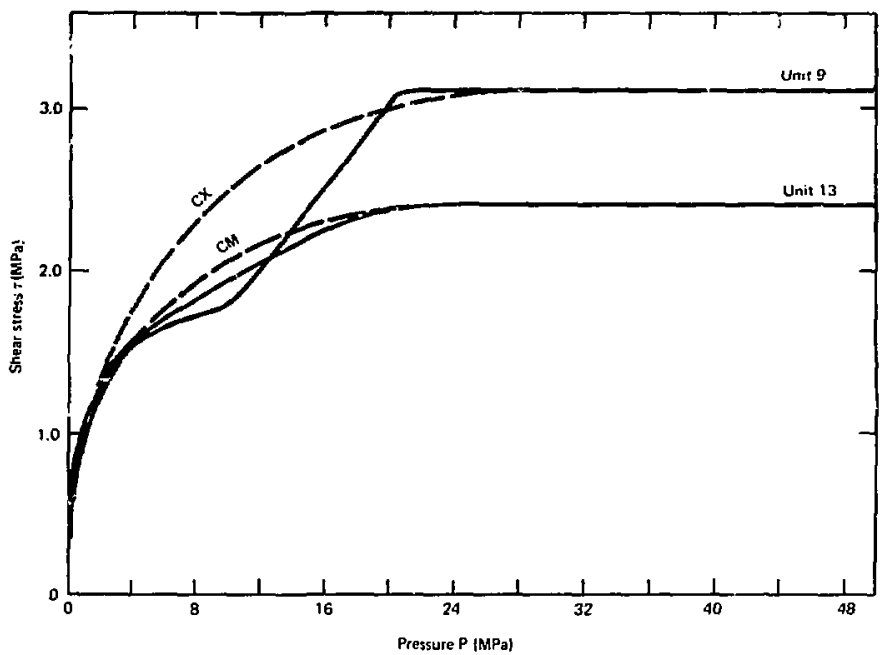

F1g. 9. Fallure cirves for unsaturated-cemented soils (CM and CX).

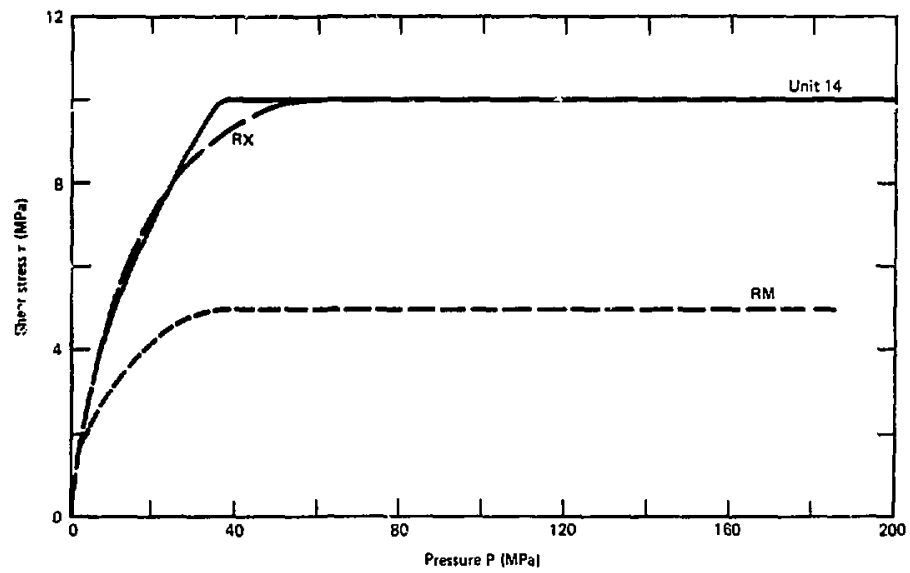

Ff:. 10. Faflure curves for weak rock (RM and RX). 
Table 7. $P_{T}, P_{M}$, and $T_{x}$ used for hypothetical solls of the Fort Pold type.

\begin{tabular}{|c|c|c|c|c|}
\hline $\begin{array}{l}\text { Fallure } \\
\text { Model }\end{array}$ & Curve & ${ }_{(\mathrm{MPa})}^{\mathrm{T} x}$ & ${ }_{\mathrm{MPa}}^{\mathrm{P}_{\mathrm{M}}}$ & $\begin{array}{c}\mathrm{P}^{\mathrm{T}} \\
(\mathrm{MPa})\end{array}$ \\
\hline $\begin{array}{l}\text { Uncemented, } \\
\text { saturated }\end{array}$ & $\begin{array}{l}\text { SM } \\
\text { SX }\end{array}$ & $\begin{array}{l}0.17 \\
0.23\end{array}$ & $\begin{array}{l}0.31 \\
0.50\end{array}$ & $\begin{array}{l}0.01 \\
0.01\end{array}$ \\
\hline $\begin{array}{l}\text { Uncerrented, } \\
\text { unsaturated }\end{array}$ & $\begin{array}{l}\text { UM } \\
U X\end{array}$ & $\begin{array}{l}\text { i. } .17 \\
1.03\end{array}$ & $\begin{array}{l}10.4 \\
14.7\end{array}$ & $\begin{array}{l}0.1 \\
0.1\end{array}$ \\
\hline $\begin{array}{l}\text { Cemented, } \\
\text { unsaturated }\end{array}$ & $\begin{array}{l}\mathrm{CM} \\
\mathrm{CX}\end{array}$ & $\begin{array}{l}2.40 \\
3.10\end{array}$ & $\begin{array}{l}21.5 \\
25.2\end{array}$ & $\begin{array}{l}5.0 \\
5.0\end{array}$ \\
\hline Weak rock & $\begin{array}{l}\text { RM } \\
\text { RX }\end{array}$ & $\begin{array}{l}5.0 \\
10.0\end{array}$ & $\begin{array}{l}34.5 \\
60.0\end{array}$ & $\begin{array}{l}8.0 \\
8.0\end{array}$ \\
\hline
\end{tabular}

same for each set of curves for all four fallure models. Their values were derived by averaging the values given for each group of Eort Polk units.

Table 7 summarizes $\tau_{X}, P_{M}$, and $P_{T}$ for each of the efght Eallure curves.

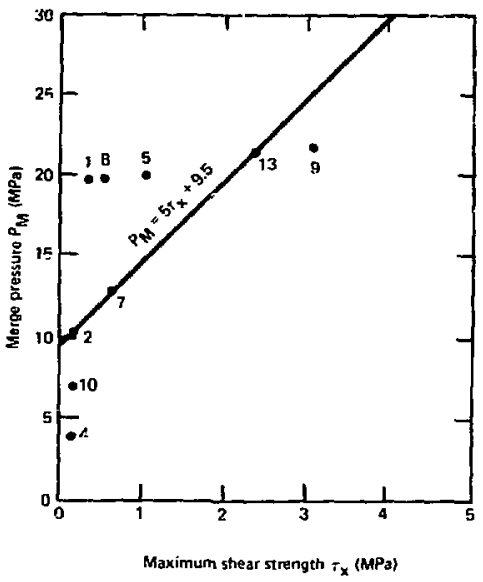

F1g. 11. Merge pressu: $P_{M}$ vs maximum shear strength $\tau_{x}$ for Fort Polk units.

\section{Culculations Performed}

ZONING, MATERIAL BOUNDARIES AND INITLAL CONDITIONS

A hypotherical nuclear source with an energy yleld of $84 \mathrm{GJ}(0.02 \mathrm{kt}$ ) was used for all calculations. It was represented by a sphere of iron gas infelally having a $0.27-m$ radius, a 370-GPa pressure, and a $1.5-\mathrm{Mg} / \mathrm{m}^{3}$ density. The equation of state of the Iron gas used in 50C74 was developed by Chapin and Butkovich. ${ }^{15}$

Tise nuclear source was sticrouncied by a spherical shell of hypothetical soil extending from the source radius to a radius of
$200 \mathrm{~m}$, which is effectively infinite for these problems. Thus there were no reflections from the outer boundary during the 20-msec simulation.

Bath source and soil were divided into zones consisting of concentric spherical shells. The source contained 20 zones of equal thickness, while the soil contained 505 zones varying in thickness according to a geometrical progression from $0.0136 \mathrm{~m}$ at the edge of the source to about $2 \mathrm{~m}$ at the outer edge oi the problem (200 m). The initial state of the problems, including zoning and initlal source conditions, is shown diagramat lcally in Fig. 12. 


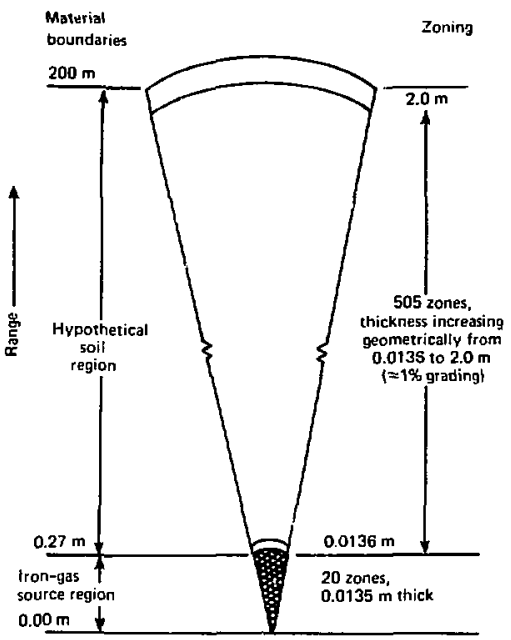

Fíg. 12, Dlagram of z.onfing and material boundaries for SOC74 hypothet1cal nuclear problems.
BULK PROPERTY AND CONSTITUT'VE-RELATION INPUT FOR IRDIVIDUAL CALCULATIONS

Results from 25 soc74 calculations are included in this report. For convenience In referring to Individual calculations, tanemonics were developed. The mnemonic is of the following form:

$$
F-\rho_{0} / s^{\omega}
$$

where $F$ gives the letter designation of the fallure model used (e.g., UM or CX). The middIe part, $\rho_{0} / S_{w}$, gives the initial values of $\rho_{0}\left(\mathrm{Mg} / \mathrm{m}^{3}\right)$ and $s_{w}$ uged. There were only two calculations with values of $K$ that differed from $5.0 \mathrm{GPa}$. For these two calculations the value of $K$ is $1 n$ cluded in parentheses to the right of the mnetoonic. (See Table 8, p. 18.)

The compresstbility curves on loading and unloading, for each of the 25 calculations, are included in Appendix $A$, This

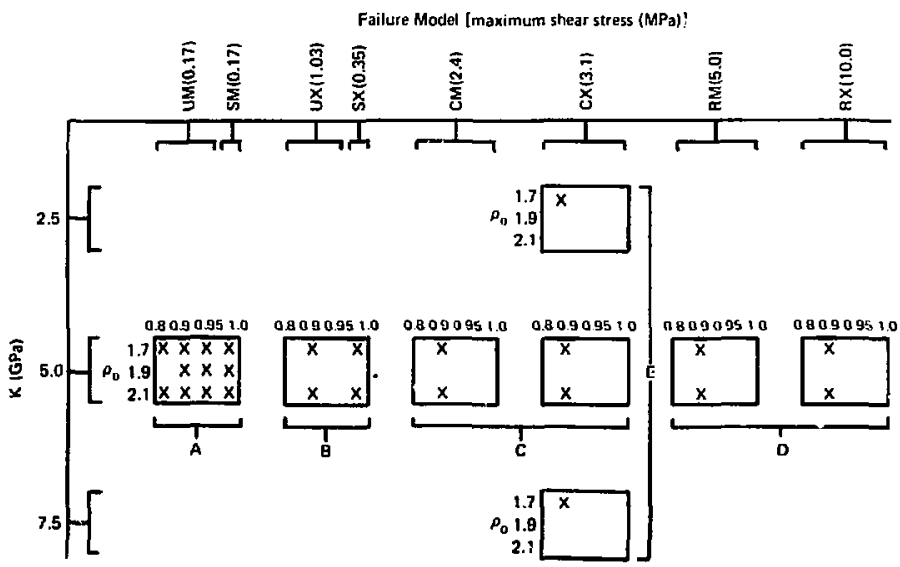

818. 13. Sumary of calculations performed in the parameter study. 
Information, together vith the appropriate Eallure curve (Ftgs, 7, 8, 9, or 10) describes completely the input for each calculat lon.

ORGANIZATION OF THE. CALCULATIONS

Figure 13 shows the organization of the calculations. The values of al1 four $\mathrm{in}^{-}$ dopendent variables ( $\hat{p}_{0}, S_{w}, \boldsymbol{K}$, and fallure model) are shown for each calculation.

This was accomplished by constructing a series of swall two-dimenstonal grids (In $\rho_{0}$ and $s_{w}$ ) and then overlaying a large two-dimensional grid In $\mathrm{K}$ and fallure model. The small grids within the large grids are positioned so as to reflect the correct value of $K$ and the correc faflure modei. The locations of the X's within each suall grid give the values of $\rho_{0}$ and $s_{w}$. Thus the calculations needed to 1nvestigate the effect of a particular Independent variable can be readily identified. For example, the effect of dersity can be determined with the calculations performed for $K=$ $5.0 \mathrm{GPa}$ and for all faflure models at $\mathbf{S}_{\mathbf{w}}=$ 0.9. In addition, it can be determined for the UM-SM fallure curves for $S_{w}=0.9$, 0.95 , and 1.0 .

Figure 14 shows the calculations performed in $\left(\rho_{0}, s_{w}\right)$ space, overlaid on FIg. 3. This shows that the Ifmits of the

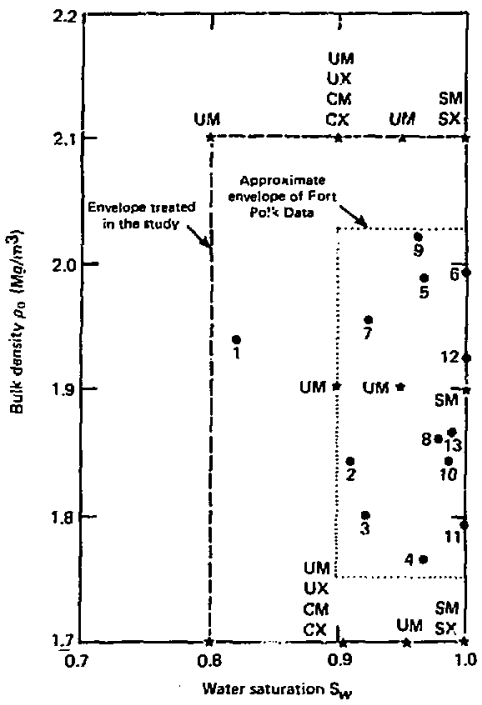

F1g. 14. Plot of calculations performed In $\rho_{0}-s_{w}$ space.

study are covered suffictently in that space, for all faliure curves typical of the 13 Fort Polk untts. It can also be seen that most of the calculations performed vere at $s_{w} \geq 0.9$. Thus the study was blased toward the region where most of the Fort Polk data is concentrated.

\section{Calculational Results}

PHENOMENOLOGY OF THE NUCLEAR DETONATION

The total yield, 84 GJ (20 tons), tesides inttially In the sphere of Iron gas representing the nuclear device. The high Initial pressure in the fron gas causes it to expand rapidly, compressing the surroundIng so11. For a short time after energy release $(-19$ Heec) the shock wave generated 2.1 the sol1 by the Iron-gas expanston is strong enough to vaporize the soll (pressures exceeding $110 \mathrm{GPa}$ ). The shock wave 
attenuates very rapidly, and by the time 1t has reached a range of approximately $0.55 \mathrm{~m}$, It $1 \mathrm{~s}$ unable to cause further soll vaporlzatlot. Since this radius is roughly twice the initial radius of the Iron-gas regton $(0.27 \mathrm{~m})$, the total mass of vaportzed oo1.!. Is considerably greater (roughly by a factor of 1 )) than the mass of the nuclear source. The combined mass of Iron gas and vaportzed soll, then. comprises the nuclear cavity, which continues to expand into the surrounding soll.

Sphertcal divergence and inelastic effects continue to attenuate the peak pressures as the shock wave travels beyond the sall-vaporization radius. In the pressure regions between 10 and 100 GPa, the shock wave can vaporlze the free

Table 8. Figures giving plots of kinetic er -rgy vs tiwe and peak stress and particle velocity vs range for the $25 \operatorname{soc74}$ calculations.

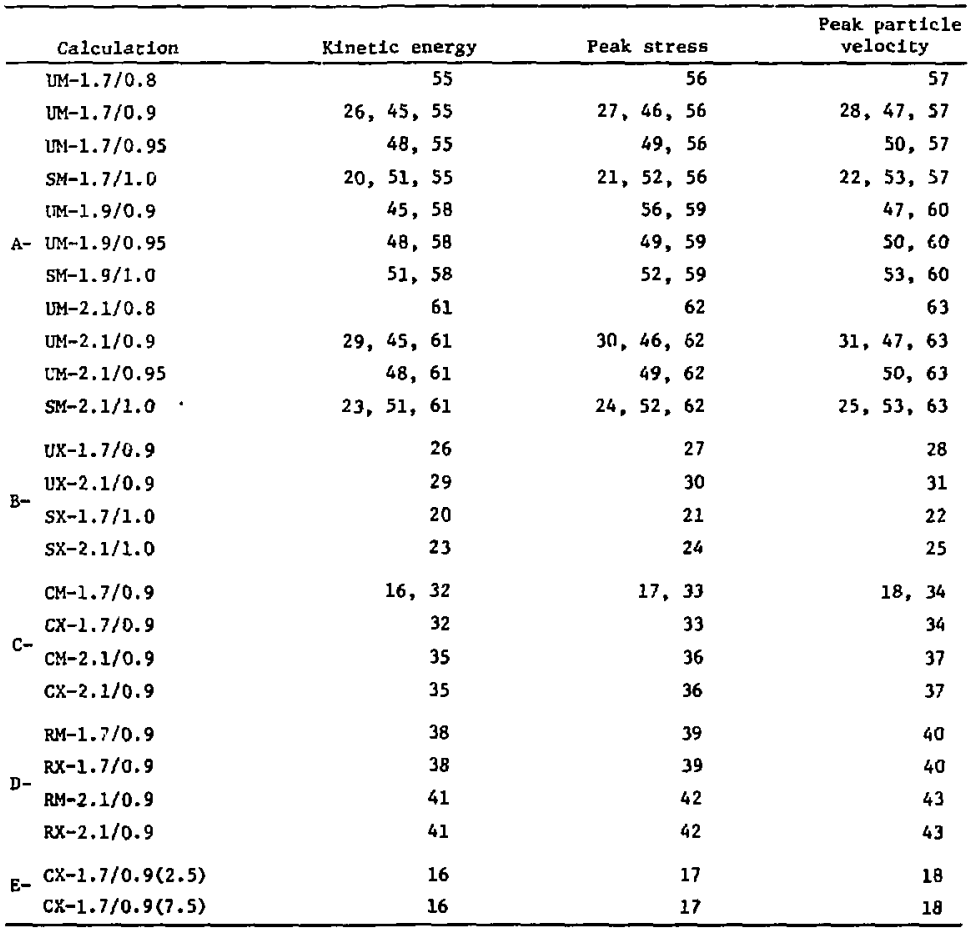


water contafned in the soil (but not the solfd material), As cavity expansion continues, the gas pressure drops and rad1al expansion decelerates. A typical plot of cavity pressure versus time is shown in F1g. 15. By the time the pressure at the front drops below $10 \mathrm{GPa}$, it has separated from the cavity and has started to propagate in a manner sfmllar to a shock wave driven by high explosive in the same soll.

EEFECT OF INDEPENOENT VARIABLES ON GROLND MOTION AND ENERGY COUPLING

Th1s section reviews the direct results obcalned from 25 soc 44 calculations. Many quantities can be obtained from soc74, as a function elther of range or of time. The results presented in this section are limited mainly to kinetic energy coupled to the soll and to peak etress and particle veloc1ty versus range in the soil. The calculacional results are compared in order to show the effect of each of the four independent variables: $K$, failure envelope, $p_{0}$, and $s_{w}$.

Location of Plots for Individual Calculat lons

In order to allow for comparibons other than thase presented in this section, Table 8 lists, for each of the 25 soc74 calculations, the figures thet can be consulted to obtain the kinetic energy versus time and peak stress and particle velocity versus range. They are grouped according to the letter designations " $A$ " through " $\mathrm{E}$ ", as shown in Fig. 13.

\section{Effect of Intt Lal Bulk Modulus}

As already mencioned, the effect of the infelal bulk modulus $K$ on ground motlon was

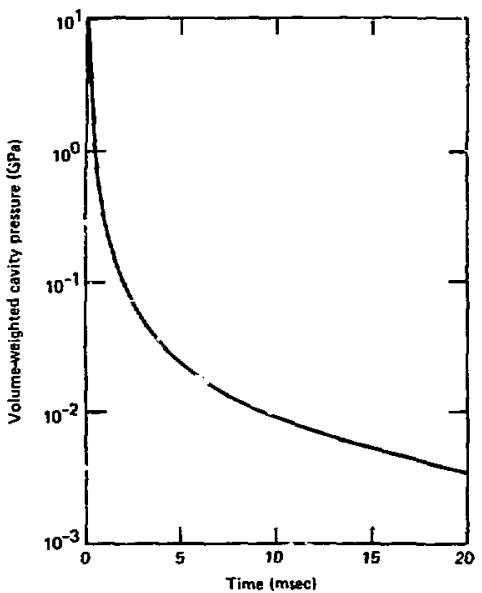

F1g. 15. Typical curve of cavity pressure vs time for an 84-GJ (20-ton) nuclear detonetion, $Z=20 \%$.

ielt to be mintmal. Therefore only two calculationg vere performed with values that differed irom $5.0 \mathrm{GPa}$ : $\mathrm{CX}-1.7 / 0.3$ $(2.5)$ and $C X-1.7 / 0.9(7.5)$, where $k$ vas equal to 2.5 and $7.5 \mathrm{GPa}$, reepectively. Unsaturated, cemented hypothetical solls were chosen for the variation of $k$ in order to maxtofze the effect for solls typical of Fort Polk. Figure 16 whows the kinetic energy coupled to the soll for the two calculations referred to above and CX-1.7/0.9 (chis calculation according to the convention used in this report, has $k=$ $5.0 \mathrm{GPa})$. The three curves are nearly the sawe, Indicating that varying $k$ does not affect the coupling of kinetic energy. Cratering ic directly related to the coupled kinetic energy, and hence $k$ also does not affect cratering. Flgures 17 and 18 show, for the ane three calculations, the 


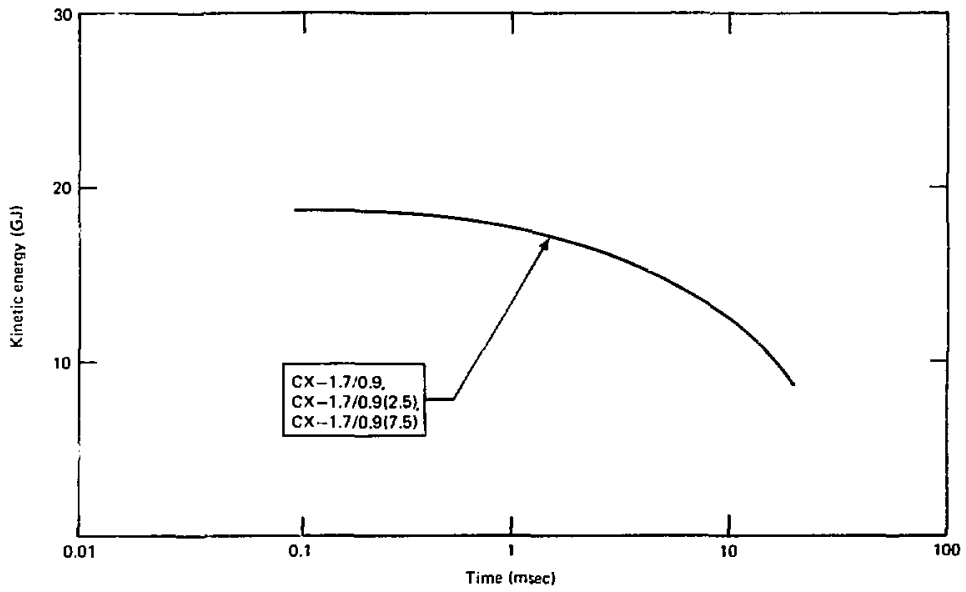

F1g. 16. Effect of $K$ on kinetic energy vs time.

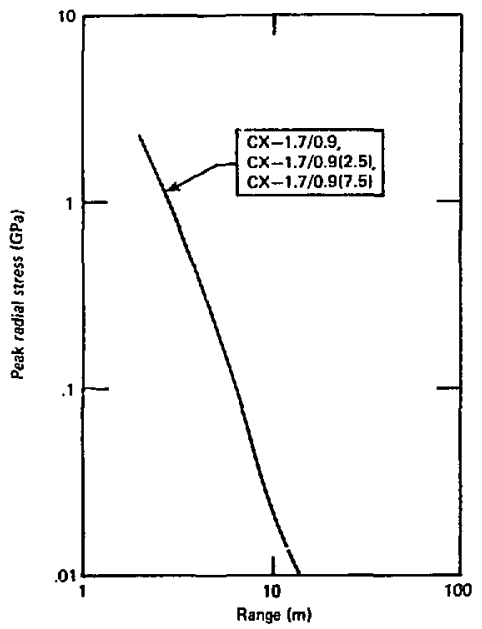

Fig. 17. Effect of $K$ on peak stress va range.

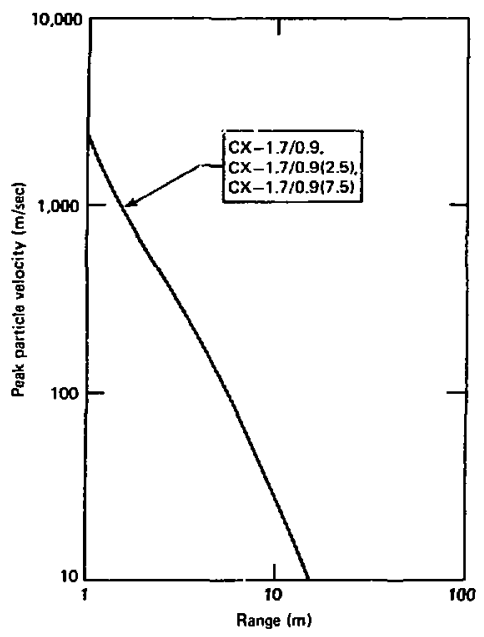

Fig. 18. Effect of $K$ on peak particle velocticy ys range 


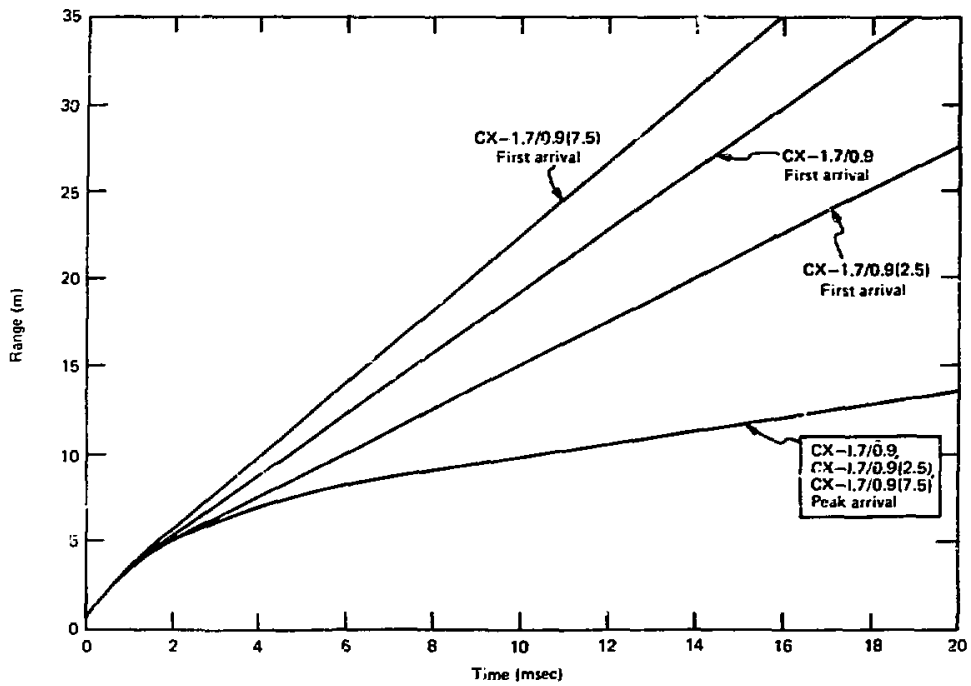

Fig. 19. Effect of $\mathrm{K}$ on first arrival and peak arrival tires.

peak stresg versus range and peak particle velocity versus range, respectvely. Again, varying $K$ has no effect on the calculaced resu1ts. Figure 19 shows that varying $\mathrm{K}$ also does not affect the peak arrival time. First arrival, however, is affected because $K$ determines the velocity of the acoustic wave. Very litele kinetic energy is associated with this "precurgor," however, and consequently it has very little effect on cratering or close-in ground motion.

To suinarize, for solis of the Fort Polk type, it has only a minor effect on the close-in ground rootion and dynanlc crater formation resulting from a nuclear detonation.

\section{Effect of Railure}

In this section we analyze in two ways the effect of fallure on energy coupling and ground motion. Firgt, we compare the relative effect of the maximum and minimum fallure curves (Figs. 7 through 10) for each category (e.g., uncemented, baturated soils). Second, we attempt to give the total, qualitative effect of faflure by summarizing results from all of the calculations.

Figures 20, 21, and 22 show the effect of the maximum and minimum fallure curves on coupled kinetic energy versus time, and peak stress and peak particle velocity versus range, respectively, for the uncemented, saturated solls (SM and SX) with 


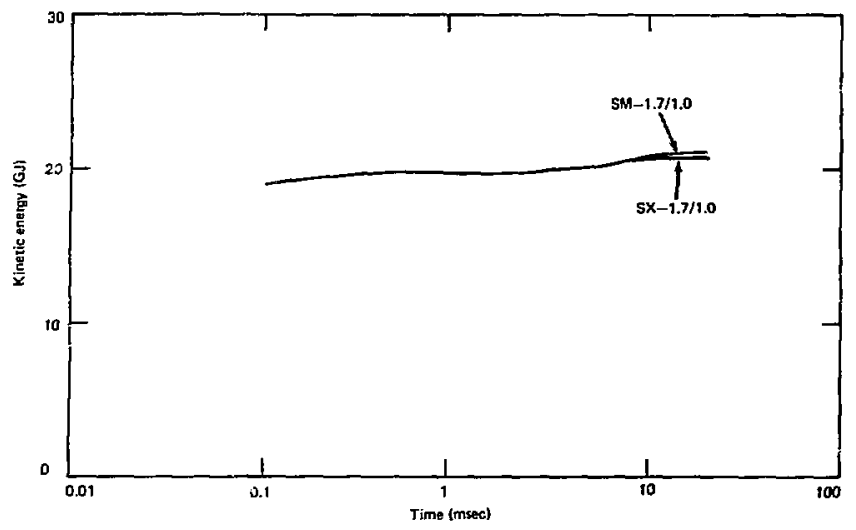

F1g. 20. Effect of fallure on coupled kfnetic energy for uncemented, saturated solls $\left\langle\rho_{0}=1.7 \mathrm{Mg} / \mathrm{m}^{3}\right\rangle$.

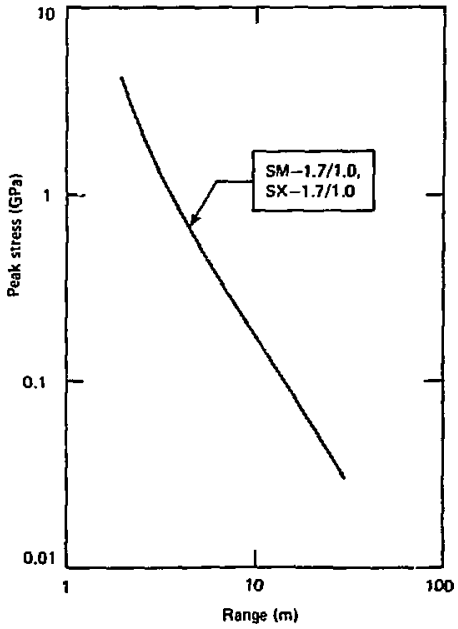

F1B. 21. Effect of faflure on peak stress ve range for wncemented, aaturatad solls $\left(p_{0}=1.7 \mathrm{Mg} / \mathrm{g}^{3}\right)$.

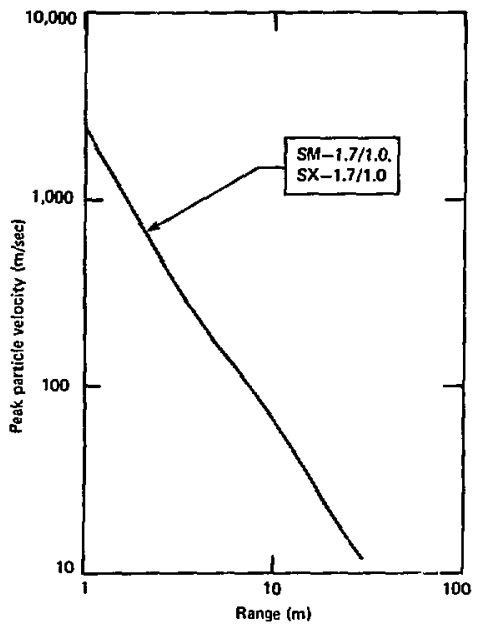

Fig. 22, Effect of fallure on peak particle velocity va range for uncemented, saturated solls $\left(\rho_{0}=1.7 \mathrm{Mg} / \mathrm{m}^{3}\right)$. 


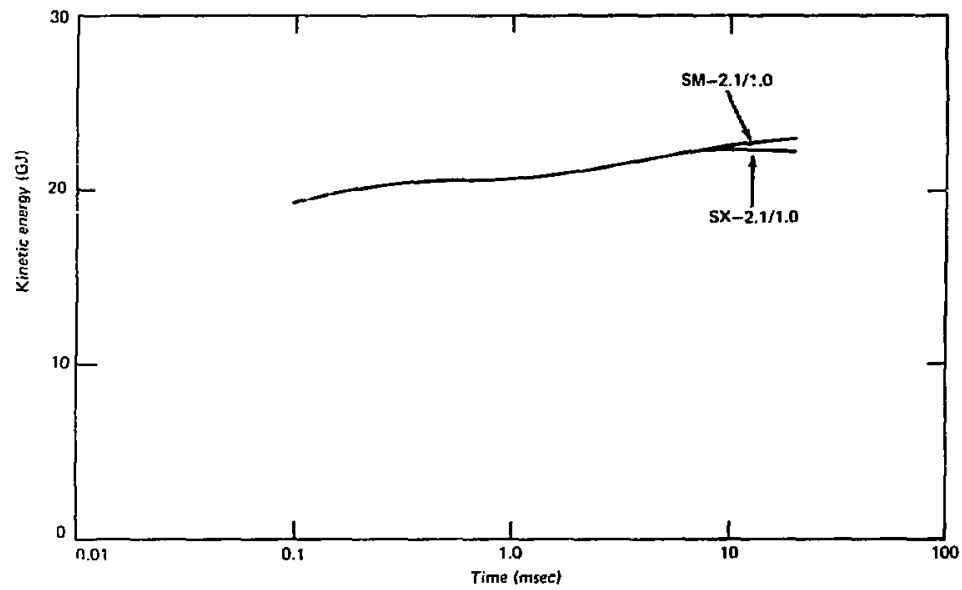

F1g. 23. Effect of fallure on coupled kinetlc energy for uncemented, gaturated solls $\left(\rho_{0}=2.1 \mathrm{Mg} / \mathrm{m}^{3}\right)$.

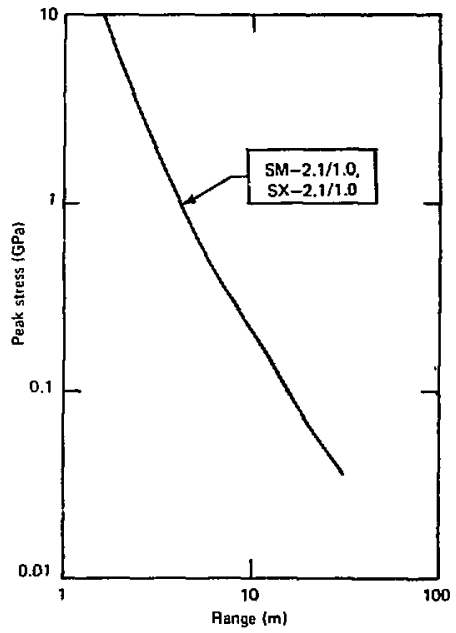

an initial bulk density $\rho_{0}=1.7 \mathrm{Mg} / \mathrm{m}^{3}$. Figures 23, 24, and 25 give the same comparison for solls with $\rho_{0}=2.1 \mathrm{Mg} / \mathrm{m}^{3}$. In all cases there are only very minimal differences between the curves, Indfeating that, for the saturated solls, elther fallure curve (or any draw between the SM and SK curves in Fig. 7) will adequately represent the entire category.

The same comparison is shoer in Figs. 26,27 , and 28 for $\rho_{0}=1.7 \mathrm{Mg} / \mathrm{m}^{3}$ and in Figs. 29, 30, and 31 for $\rho_{0}=2.1 \mathrm{Mg} / \mathrm{m}^{3}$ for the uncemented, unsaturated (UM and UX) caregory. These calculational resulte show that, although the differences

Fig. 24. Effect of fallure on peak stress vo range for uncemented, saturated sot1s $\left(\rho_{0}=2.1 \mathrm{~kg} / \mathrm{m}^{3}\right)$. 


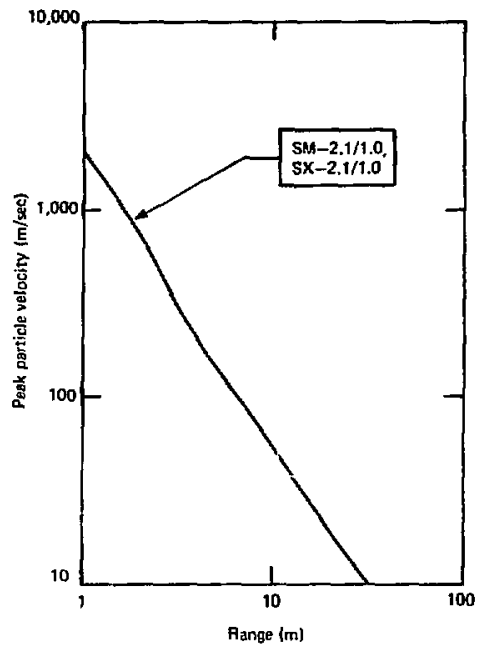

Fig. 25. Effect of fatlure on peak particle velocity vo range for uncemented, saturated solls $\left(\rho_{0}-2.1 \mathrm{Mg} / \mathrm{m}^{3}\right)$.

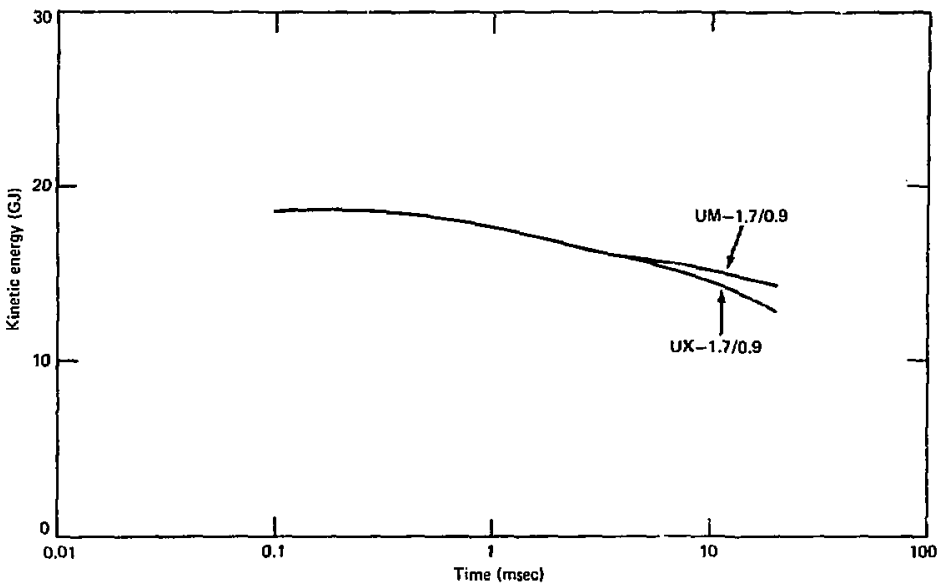

F1g. 26. Effect of fallure on kinetic energy coupling for uncemented, saturated solls $\left(S_{w}=0.9, \rho_{0}=1.7 \mathrm{Mg} / \mathrm{m}^{3}\right)$. 


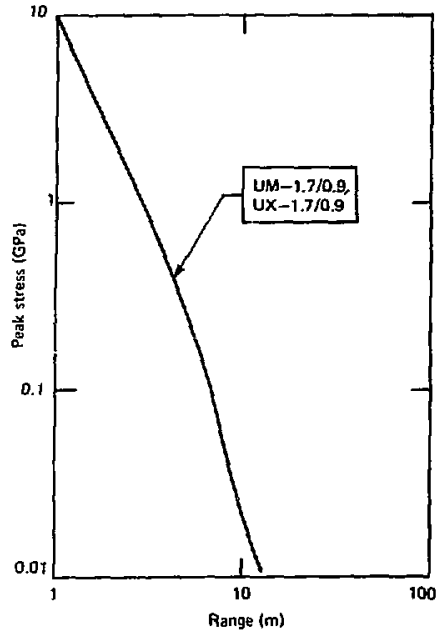

F1g. 27, Effect of fallure on peak stress vs range for uncemented, unsaturated colls $\left(S_{w}=0.9\right.$, $\left.\rho_{0}=1.7 \mathrm{Mg} / \mathrm{m}^{3}\right)$.

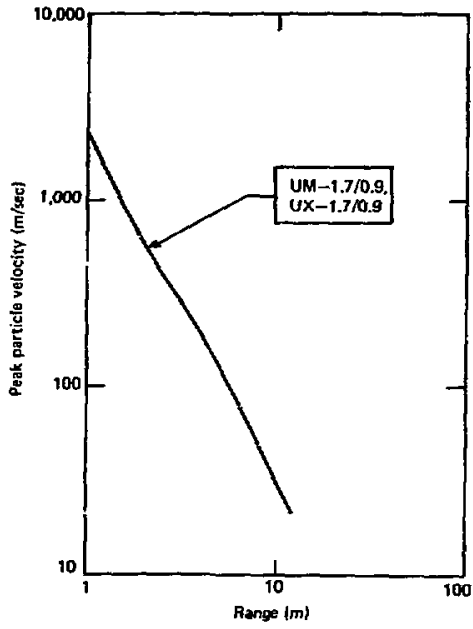

E1g. 28. Effect of failure on peak particle veloalty vo range for uncemented, unsaturated so11s $\left(S_{w}=0.9, o_{0}=1.7 \mathrm{Mg} / \mathrm{m}^{3}\right)$.

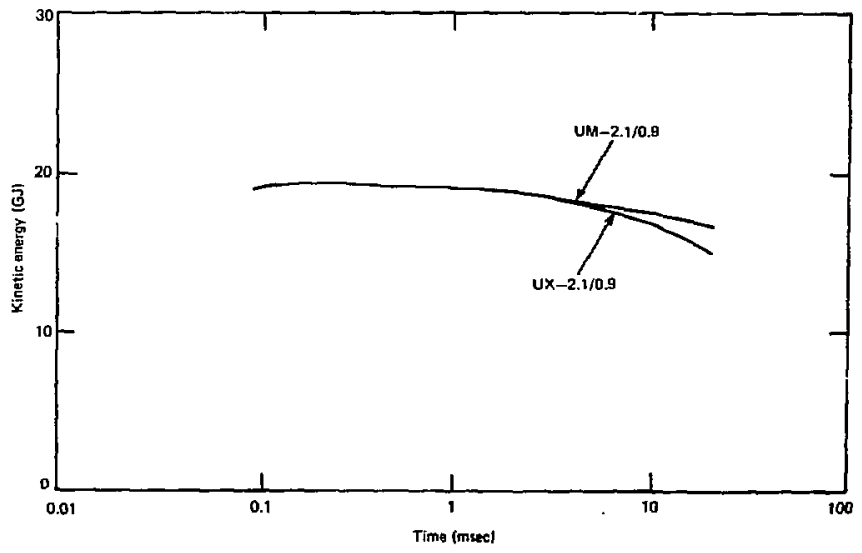

F1g. 29. Effect of fallure on coupled kinetic energy for uncenented, unsaturated sollg $\left(s_{\mathrm{w}}=0.9, \rho_{0}=2.1 \mathrm{Mg} / \mathrm{a}^{3}\right)$. 


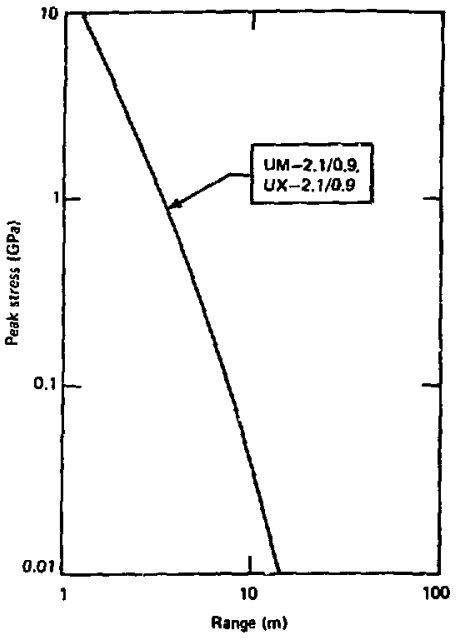

Fig, 30. Effect of fallure on peak screst vs range for uncerented, unsaturated so11s $\left(S_{w}=0.9\right.$, $\rho_{0}=2.1 \mathrm{Ng} / \mathrm{w}^{3}$ ).

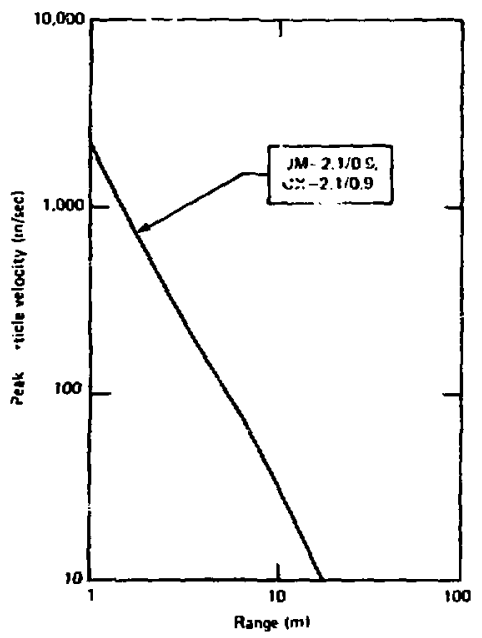

F18. 31. Effect of fallure on peak particle velocity $\mathrm{us}$ range for uncenented, unsaturated solls $\left(S_{v}=0.9, p_{0}=2.1 \mathrm{Mg} / \mathrm{m}^{3}\right)$.

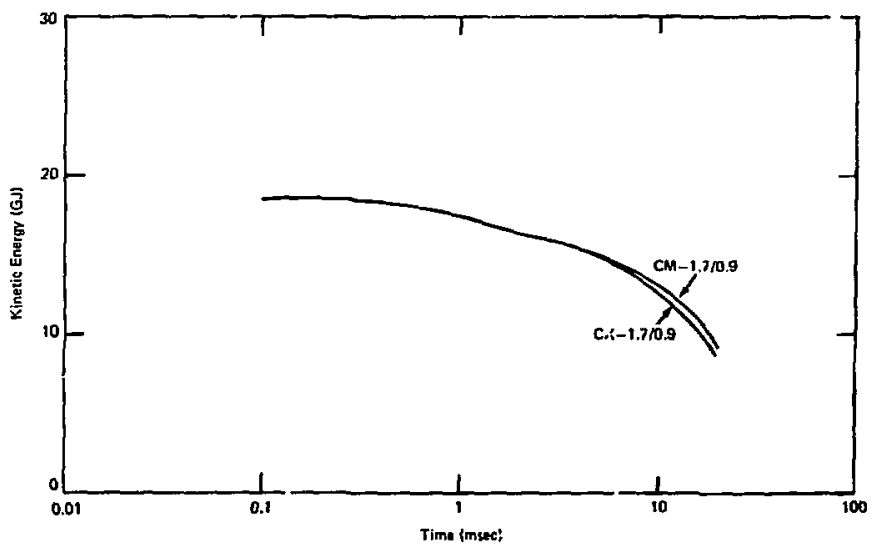

F1g. 32. Effect of fallure on kinetic energy coupling for unsaturated, cemented solls $\left(\mathrm{S}_{\mathrm{v}}=0.9, \rho_{0}=1.7 \mathrm{Mg} / \mathrm{m}^{3}\right)$. 


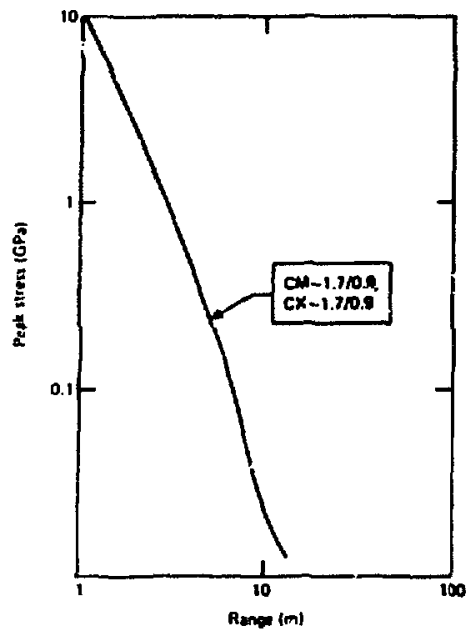

botwech the peak-atreas and peak-partielevelecity curves are very sall ot both denslites, the UX fallure eurve glves a lover coupled kitietic enet the UM eurve at late twes (O10 asec).

The above it setn to be crue also for the cobenced, unsacisrated solls, as shown in Figs. 32, 33, and i6 for $\mathrm{o}_{\mathrm{O}}-1.7 \mathrm{~kg}$ $\mathrm{m}^{3}$ and in Figs. 35, 36, and 37 for $D_{0}=2.1 \mathrm{Mg} / \mathrm{m}^{3}$. Again, for both denaites, the salculated peak stressta and particle velocttlez are not stgniftcantiy affected by the isffarence in shear strength between the $C M$ and $C X$ curves (F1g. 9).

For the ueak rock there $1 \mathrm{~s}$ a large difference berween the maxioum shear strengths of the BH and RX curvea (Fig. 10). This difference, about $5 \mathrm{MPa}$, leado to a more subatantial effect on kinetic
Fis. 33. Effeet of tallure on peak exress vs range for unsacurated. ceoenterd solis (S, -0.9 . ${ }_{0}-1.7\left(4 / \mathrm{e}^{3}\right)$.

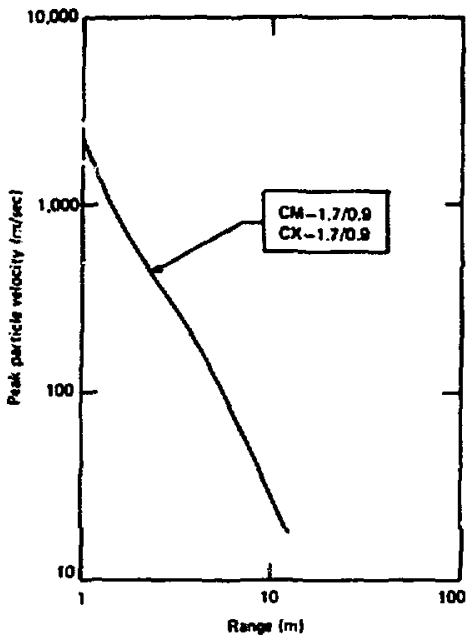

Fig. 34. Effect of fallure on peak particle veloctity va range for unsuturated, ceranted soils $\left(S_{v}=0.9, D_{0}-1.7 \mathrm{gg} / \mathrm{m}^{3}\right)$. 


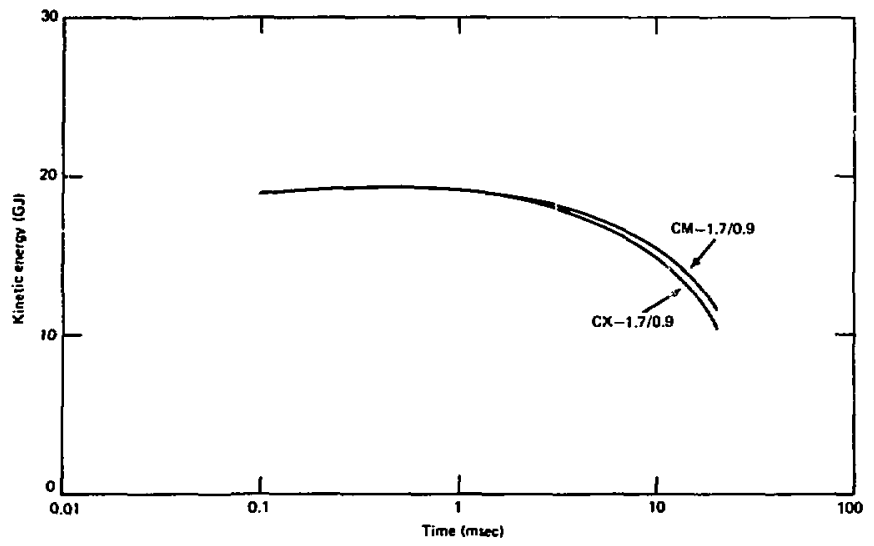

F18. 35. Effect of fallure on kinetic energy coupling for unsaturated, cemented oodls $\left(S_{w}=0.9, \rho_{0}=2.1 \mathrm{Mg} / \mathrm{s}^{3}\right)$.

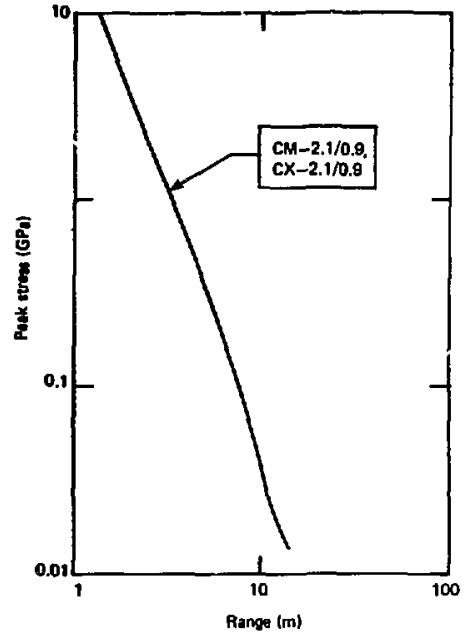

F1g. 36. Effect of fallure on peak stress va range for unsaturated, uncemented soils $\left(S_{w}=0.9\right.$, $\left.\rho_{0}=2.1 \mathrm{Mg} / \mathrm{m}^{3}\right)$.

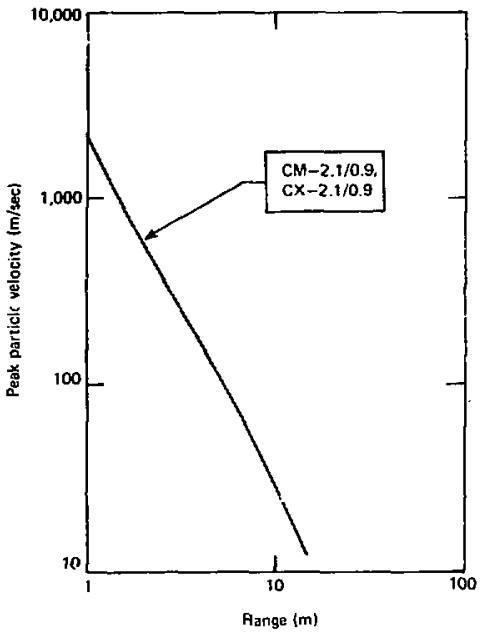

Fig. 37. Effect of fallure on peak particle velocity us range for ungaturated, cemented so1ls $\left(S_{w}=0.9, \rho_{0}=2.1 \mathrm{Mg} / \mathrm{m}^{3}\right)$. 


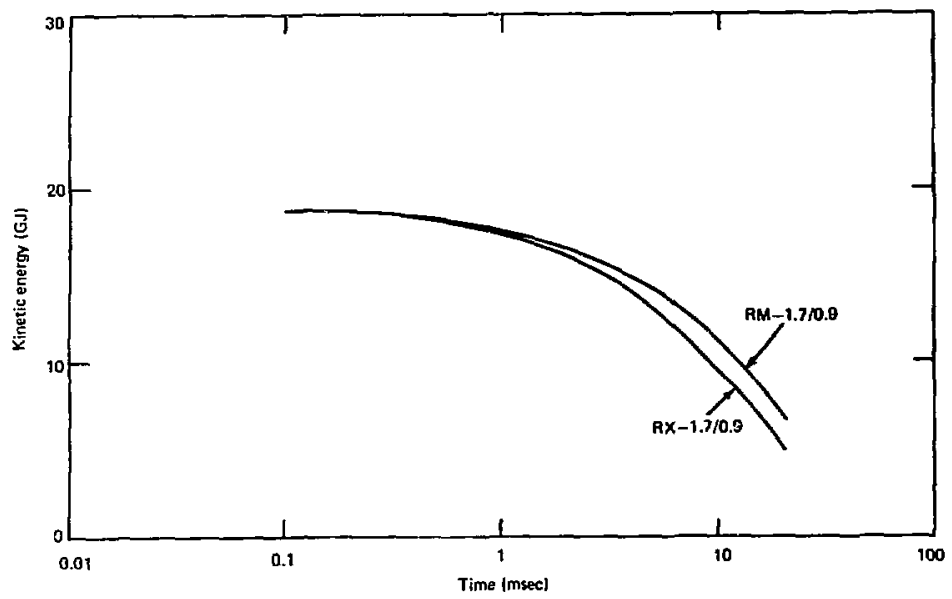

Fig. 38. Effect of fallure on kinetic energy coupling for weak rocks $\left(S_{w}=0.9, \rho_{0}=1.7 \mathrm{~kg} / \mathrm{m}^{3}\right)$.

energy coupling and to a slight, but noticeable, effect on the peak particle veloctty versus range. These effects are shown in Figs. 38,39 , and 40 for $p_{0}=$ $1.7 \mathrm{Mg} / \mathrm{m}^{3}$ and in Figs, 41, 42, and 43 for $\rho_{0}=2.1 \mathrm{Mg}^{3} \mathrm{~m}^{3}$.

Thus increasing the strength $\tau_{x}$ within any one category lowers the kinetic enerby coupled to the matertal at late times (>10 msec) and also lowers the peak part1cle velocities in the intermediate range $(\sim 10 \mathrm{~m}$ ). The peak stress, however, is not affected.

It is more interesting to look it the total effect of failure, using all of the calculations, In order to do this, the

Fig. 39. Effect of fallure on peak stress vs range for weak rocks $\left(S_{w}=0.9, \rho_{0}=1.7 \mathrm{Mg} / \mathrm{m}^{3}\right)$.

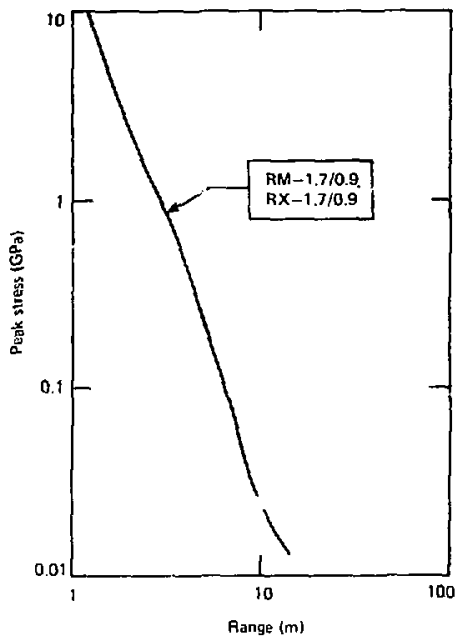


81g. 40. Effect of fallure on peak particle veloctty vo range for weak

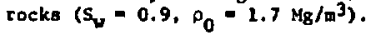
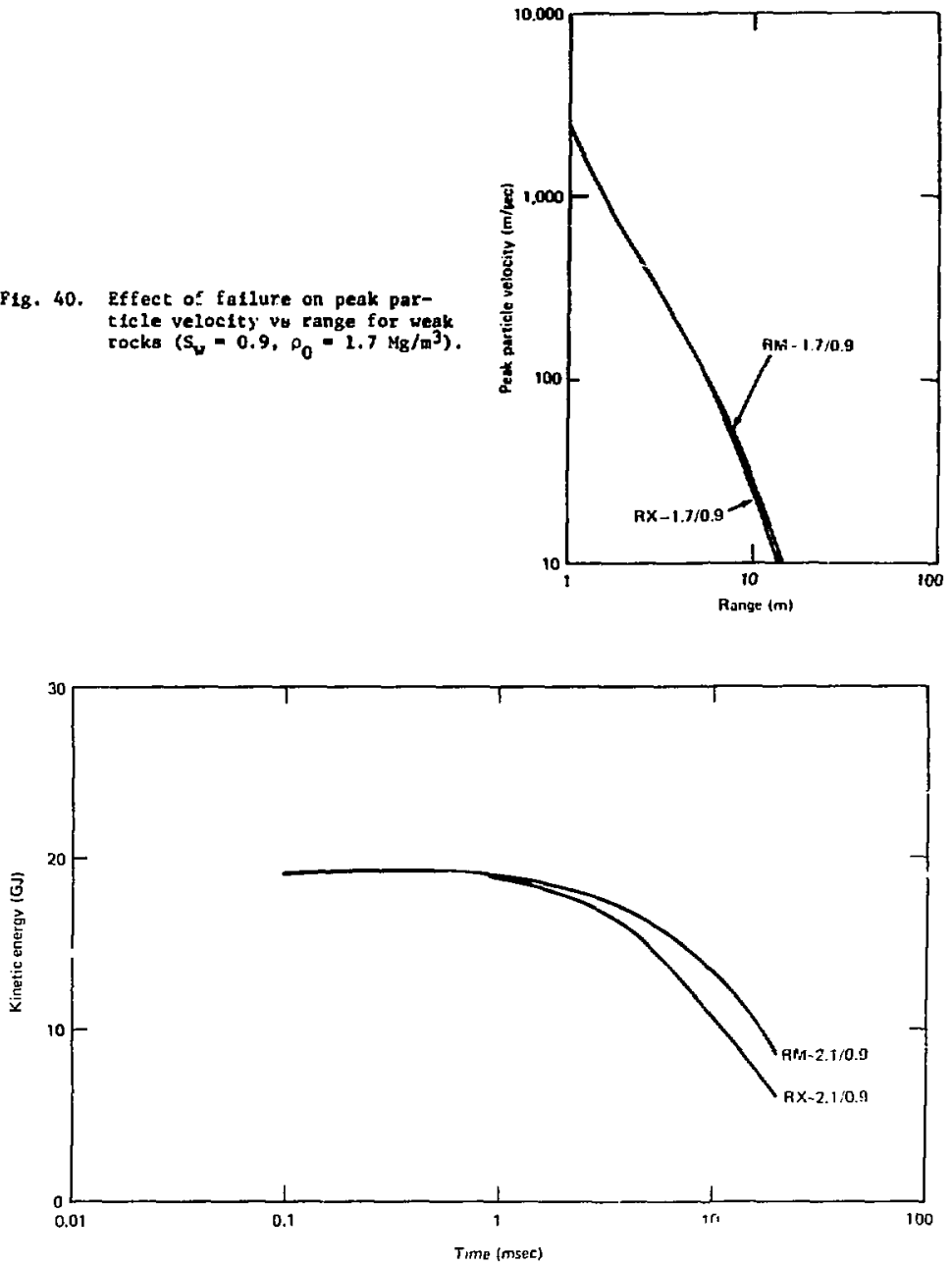
Fig. 41. Effect of faflure on kinetic energy coupling for weak rocks $\left(S_{\mathrm{w}}=0.9\right.$,
$\left.\rho_{0}=2.1 \mathrm{Mg} / \mathrm{m}^{3}\right)$. 


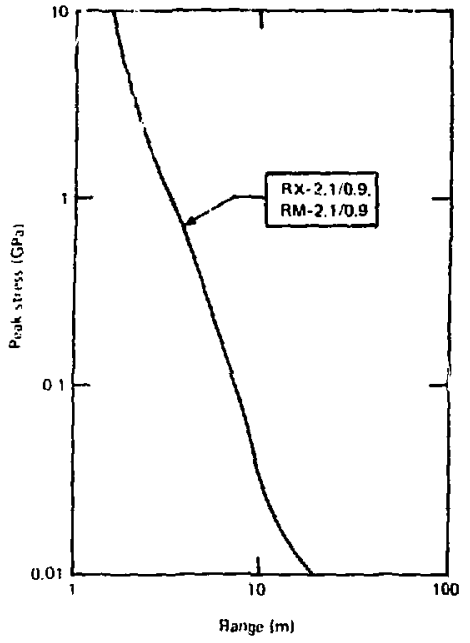

kInetic energles were plotted at a constant rlme (15 msec) and the peak particle velocitles and stresses at a constant range (12 m). This time and range vere chosen because they are very toportant to lowyield nuclear cratering at the opeimum depth of burial for soils. Higure 44a plats the coupled kinetic energy at 15 msec vers: ; $\tau_{x}$. For both sets of calculations $\left\langle\rho_{0}=1.7\right.$ and $\left.p_{0}=2.1 \mathrm{Mg} / \mathrm{m}^{3}\right)$ the coupled kinetlc energy decreases with increasing $\tau$. Also, the difference between the two curves is roughiy conetant. FIguree $44 \mathrm{~b}$ and $c$ plot the peak stress and particle velocity at the $12-m$ range versus $\tau$ ' Although the peak particle velocity decreases slowly with increasing $T_{x}$, no cletr corfelation exists for the two differient densities, as was geen for the kinetic snerglea In FIg. 44a, The peak atress seems to increase with $\tau_{x}$,
F1B. 42. Effect of fallure on peak atress ve renge for weak rocks $\left(\mathrm{S}_{\mathrm{w}}=0.9\right.$,
$p_{0}=2.1 \mathrm{Mg}\left(\mathrm{w}^{3}\right)$.

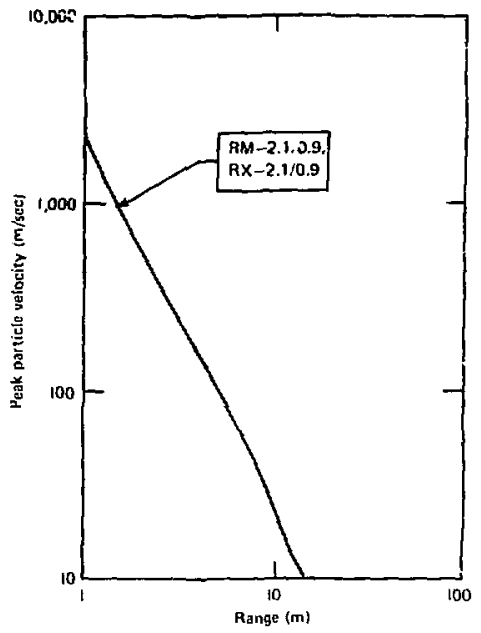

Fig. 43. Effect of fallure on peak particle velocity va range for weak rocks $\left(S_{\mathrm{w}}=0.9, \rho_{0}=2.1 \mathrm{Mg} / \mathrm{m}^{3}\right)$. 

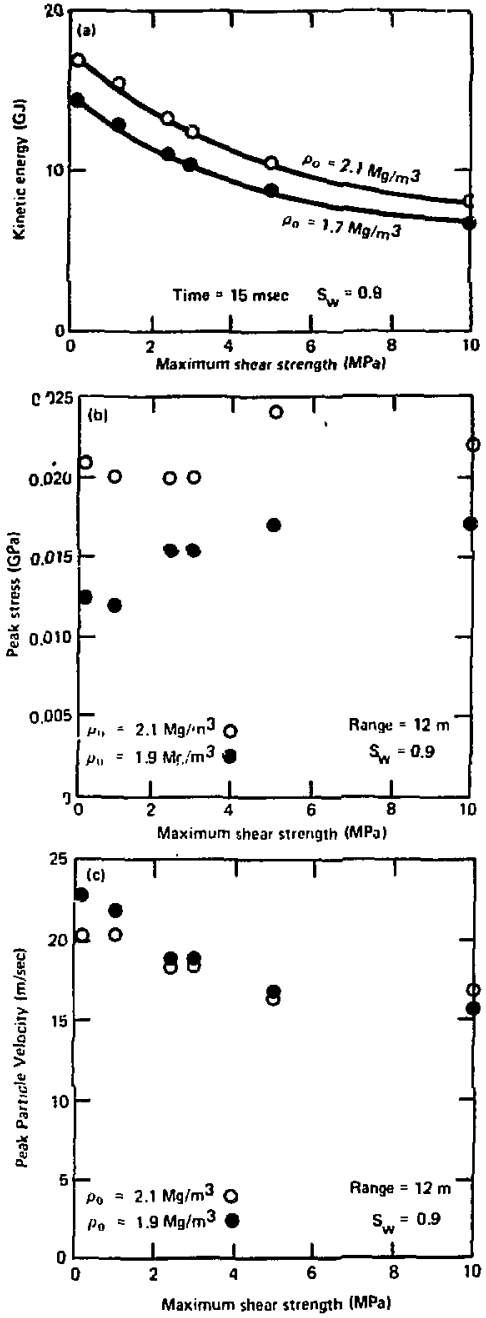

F1B. 44. Total effect of $T_{X}$ on kinetic energy coupling and ground motion. but this may not be true in light of the artificial viacosity $Q$ rsed in the soc74 code. The effect of this term in the finice-difference equations is to spread the shock front out in both $t$ fre and apace. In order for the total tmpulse to be cortect, then, the peak value wust be reduced somewhat from itg "true" value. As $Q$ is increased, the effect increases. Since higher values of $Q$ are required for the lower strength solls than for the weak rocks ( $\tau_{x}>5.0 \mathrm{MPa}$ ), the calculated peak-stress valucs at the lower values of $\tau_{x}$ on both the $o_{0}=1.7$ and $c_{0}=2.1 \mathrm{Ng} / \mathrm{m}^{3}$ curves are actually slightly higher. This indicaces, then, that tiere is essentally no vartation of peak stregs with $T_{\boldsymbol{x}}$.

\section{Effect of Density}

As can be seen from Fig. 13, calculations were performed for hypothetical solls having initlal bulk deristites of $1.7,1.9$, and $2.1 \mathrm{Mg} / \mathrm{m}^{3}$. In che preceding section it was found that both peak stress and peak particle velocity were not affected strongly by the maxinum shear strerigth. The kinetic energy was affected, but the effect was sinflar tor both of the detisities $\left(\rho_{0}=1.7\right.$ and $\rho_{0}=2.1 \mathrm{Mg} / \mathrm{m}^{3}$ ) used. In order to study the effect of dengli:y, then, the fallure curve, as well as $k$, sould be held constant. For the unsaturated solls, the UM curve (Fig. B) was use:; for the saturated solls, the SM curve (Fig. 7) was used. By using the results given in the preceding section, the effect of density can be found for all failure models within the scope of the atudy.

Figure 45 shows the affect of $\rho_{0}$ on kInetic energy colipiling versus time for 


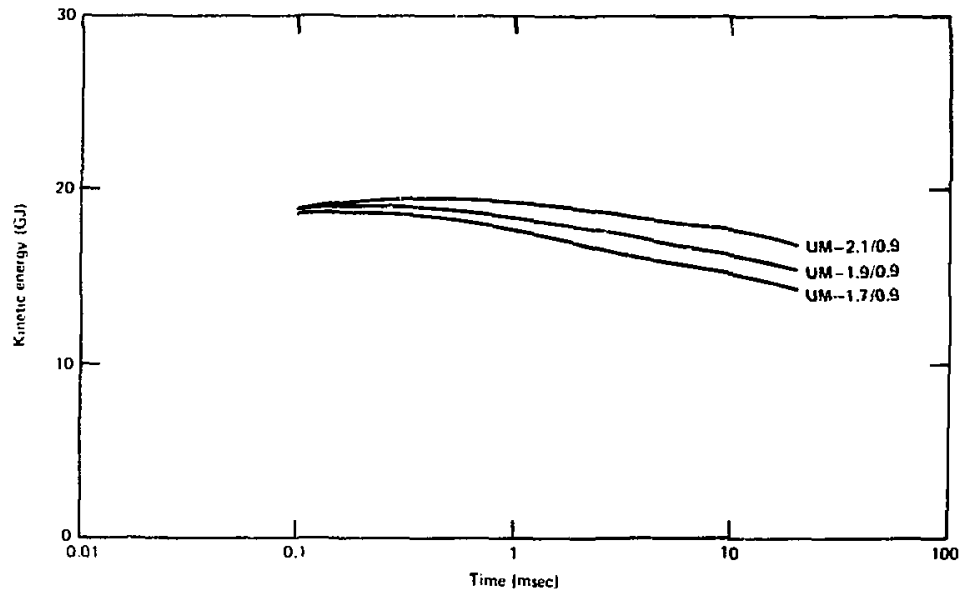

Fig. 45. Effent of denstty in kinecic energy coupling (uncemented solls, $s_{w}=0.9$ ).

$S_{w}=0.9$. Generally, increasing $\rho_{0}$ increases the kinetic energy coupled to the soll. Figures 46 and 47 show the effect of $D_{0}$ on peak stress and peak particle velocity versus range, respectively (also for $\left.S_{w}=0.9\right)$. When $o_{0}$ is increased, the peak stress also increases, but tine peak particle veloctty decreases slightly.

F1gures 48,49 , and 50 show the same comparison for $S_{w}=0.95$ and Figs. 51, 52, and 53 for $s_{w}=1.0$. The general effecc 1s the same at all three saturations: increasing $\rho_{0}$ increases the coupled kfnetic energy and peak stress, and derreases slightly the peak particle velocity.

In order to examine the total effect of density, Fig. 54 a shows the coupled kinetic

Fig. 46. Effect of density on peak stress vs range (uncemented solls, $\left.S_{w}=0.9\right)$.

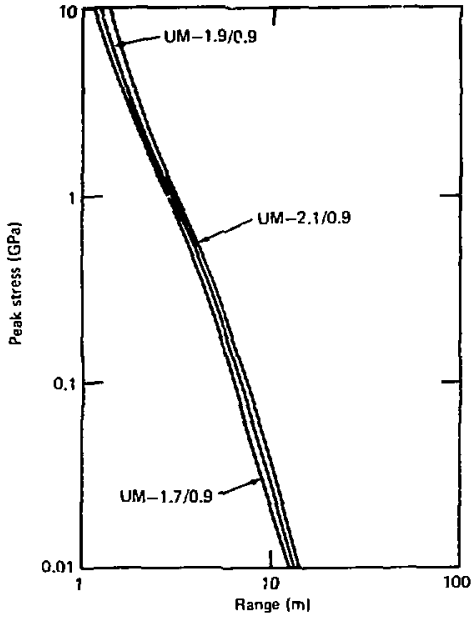




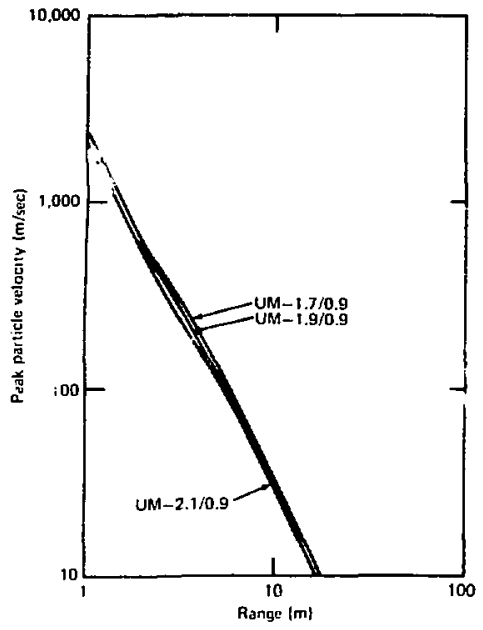

F1g. 47. Effect of denstey on peak particle velocity vo range (uncemented sot16, $\left.S_{w}=0.9\right)$.

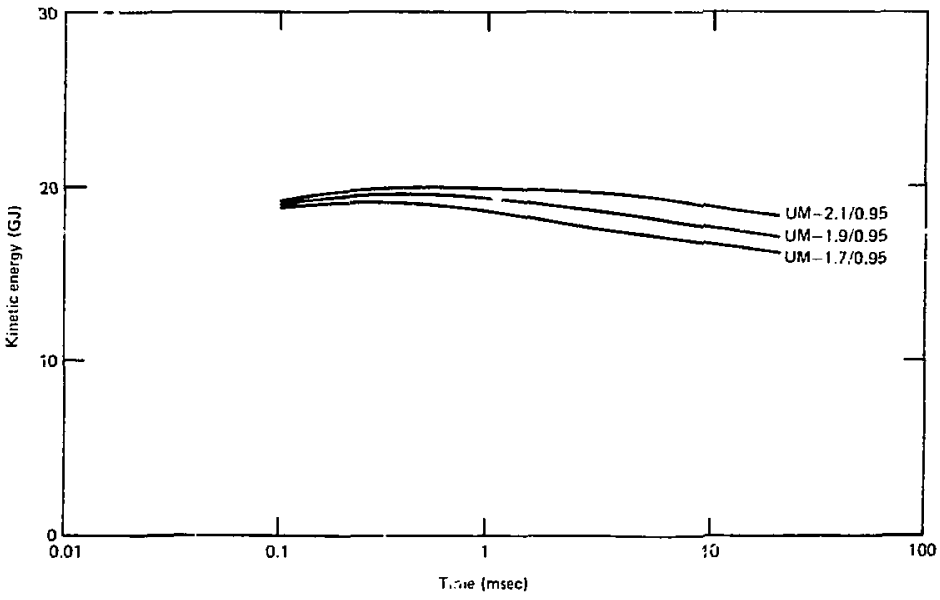

Fig. 48. Effect of density in kinetic energy coupling (uncemented scils, $S_{w}=0.95$ ). 


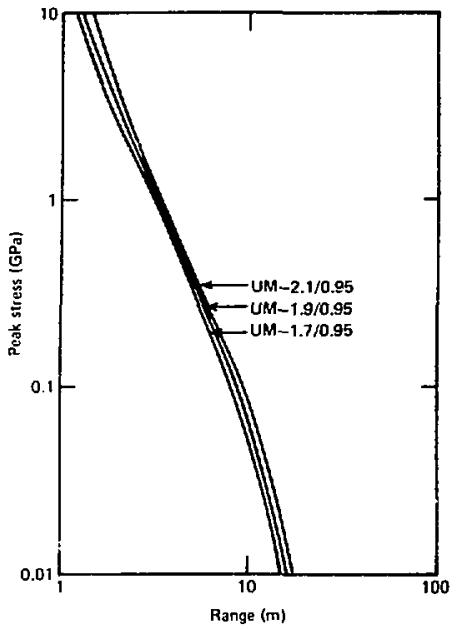

F1g. 49. Effect of densiey on peak streso vs raage (uncemented so11s, $\left.s_{w}=0.95\right)$.

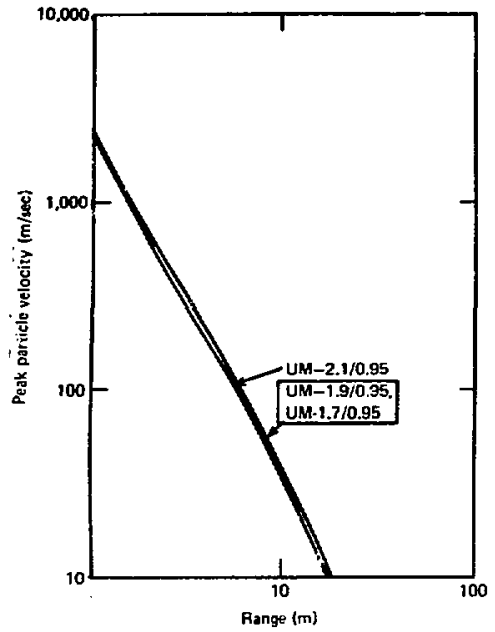

Fig. 50. Effect of density on peak particle velocity vs range (uncemented so11s, $S_{w}=0.95$ ).

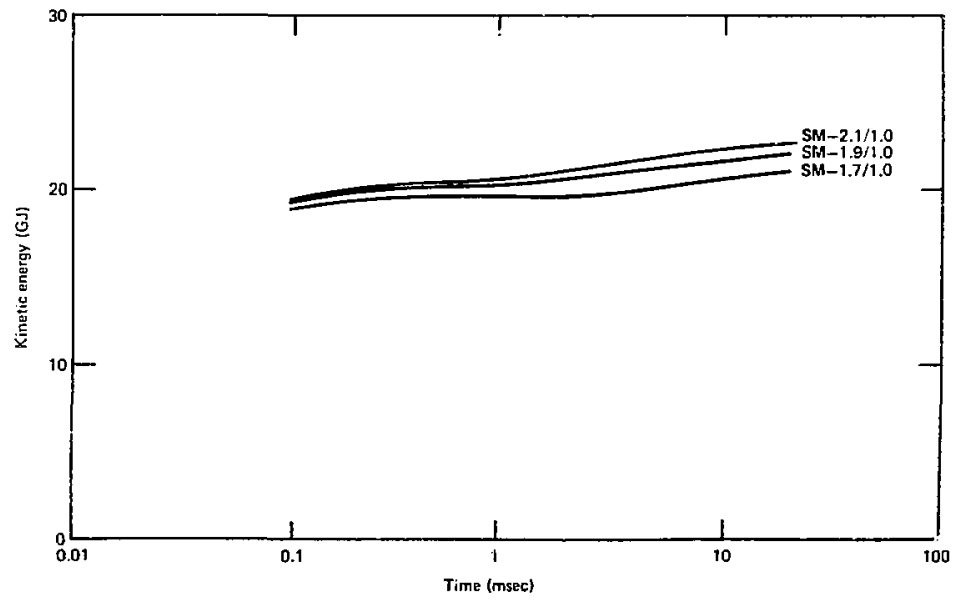

F1g. 51. Effecc of density on kinetic energy coupling (uncemented sot1s, $S_{w}=1.0$ ). 


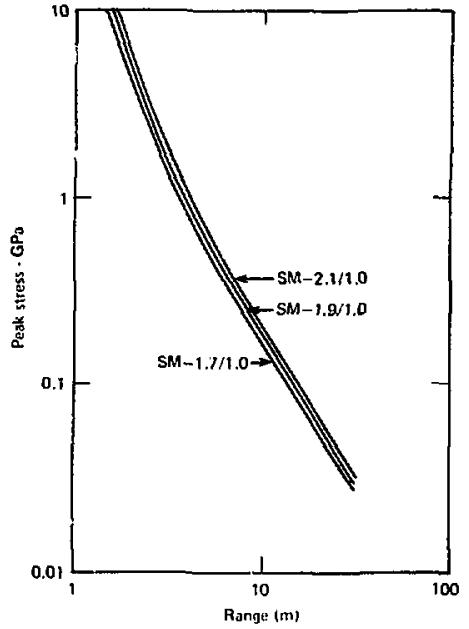

F18. 52. Effect of density on peak stress vs range (uncemented solls, $\left.s_{w}=1.0\right)$.

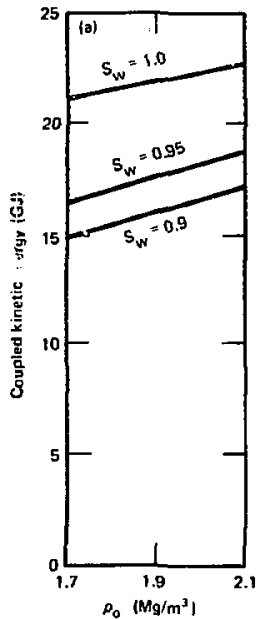

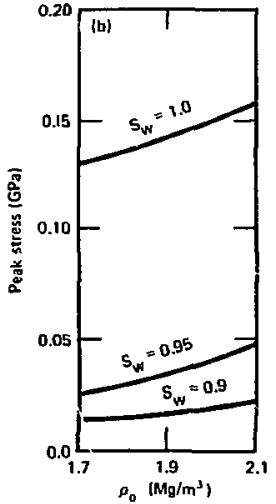

F1g. 53. Effect of density on peak particle velocity vs range (uncemented solis, $S_{w}=1.0$ ).

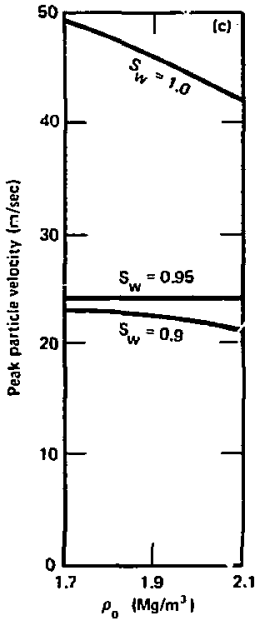

F1g. 54. Totel effect of $p_{0}$ on kinetic energy coupling and ground motion. 
energy at $15 \mathrm{msec}$ versus $P_{0}$, and Figs. 54b and $c$ show the peak stress and peak particie velocity, respectively, at a range of $12 \mathrm{~m}$. At al1 three values of $\mathrm{s}_{w}$, the kinetic energy increases inearly with $\rho_{0}$. The coupled kinetic energy at any time is the integral over all space of the density $p$ times the square of the particle veloc1ty. By increasing $p_{0}$, the quantity difectly affected is $\rho$; hence one might expect a linear increase in the coupled kinete energy with increasiog $p_{0}$. Figure $54 \mathrm{~b}$ shows that the peak stress is also almost 1 Inearly proportional to $\rho_{0}$, especially for $s_{w}=1.0$. The peak-particlevelocity plot (FIg. 54c) shows that the effect of $t_{0}$ is strong only for $s_{w}=1.0$.

In conclusion, knowledge o:: the initial bulk density $\rho_{0}$ is shown calculationally to be important; it ia a convealent variable because all three calculational quan- titles examined are roughly itnearly proportional to 1 .

\section{Effect of Saturation}

The effects of three of the four Independent varlables have been discussed so far in this section. They have been discusped in thei- order of increasing 1mporbance to ground motion and cratering: $K$, fallure, and density. This section reviews the effect of saturation at three diffezent Initial bilk densities: $p_{0}=$ $1.7,1.9$, and $2.1 \mathrm{Mg} / \mathrm{m}^{3}$. As in the preceding section, the compartson ts made for the UM and SM fallure models and for $K=5.0 \mathrm{GPa}$.

Figure 55 shows the effect of varying $s_{w}$ from 0.8 to 1.0 on kinetic energy coupling for $\rho_{0}=1.7 \mathrm{~kg} / \mathrm{m}^{3}$. The overall effect is substantial, especially at late time (15 to 20 msec), with the kinetic

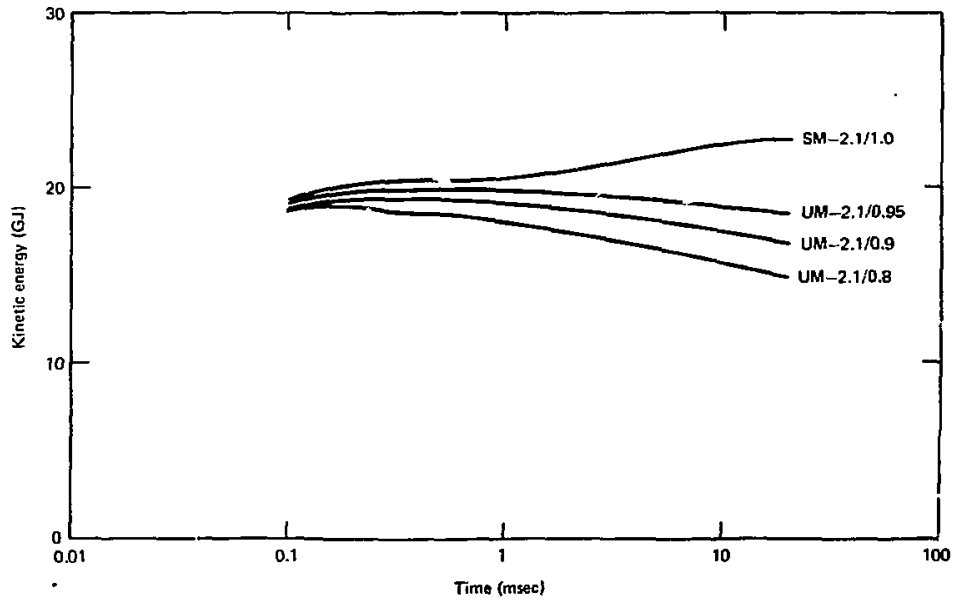

Fig. 55. Effect of saturation on kinetic energy coupling (uncemented solls, $\left.\rho_{0}=1.7 \mathrm{Mg} / \mathrm{m}^{3}\right)$. 


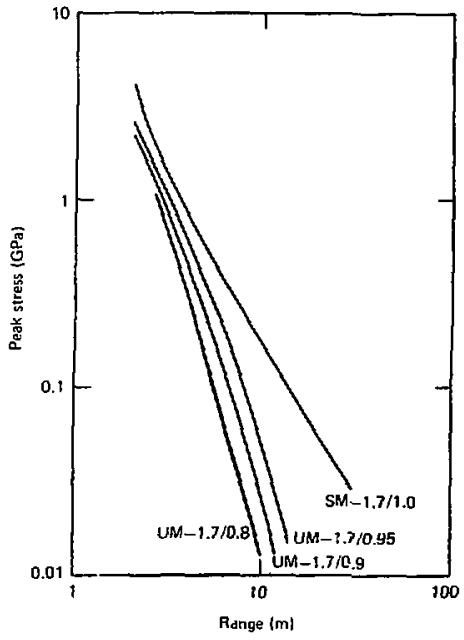

Fig. 56. Effact of saturatfon on peak stress vs range (uncemented so11s $\left.\mathrm{p}_{0}=1.7 \mathrm{Mg} / \mathrm{m}^{3}\right)$.

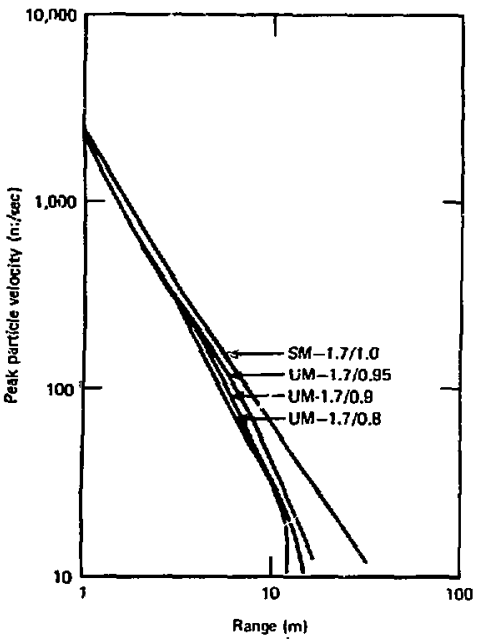

F18. 57. Ef fect of saturation on peak particle velocity yo range (uncenented solls, $p_{0}=1.7 \mathrm{M}_{\mathrm{b}} / \mathrm{m}^{3}$ ).

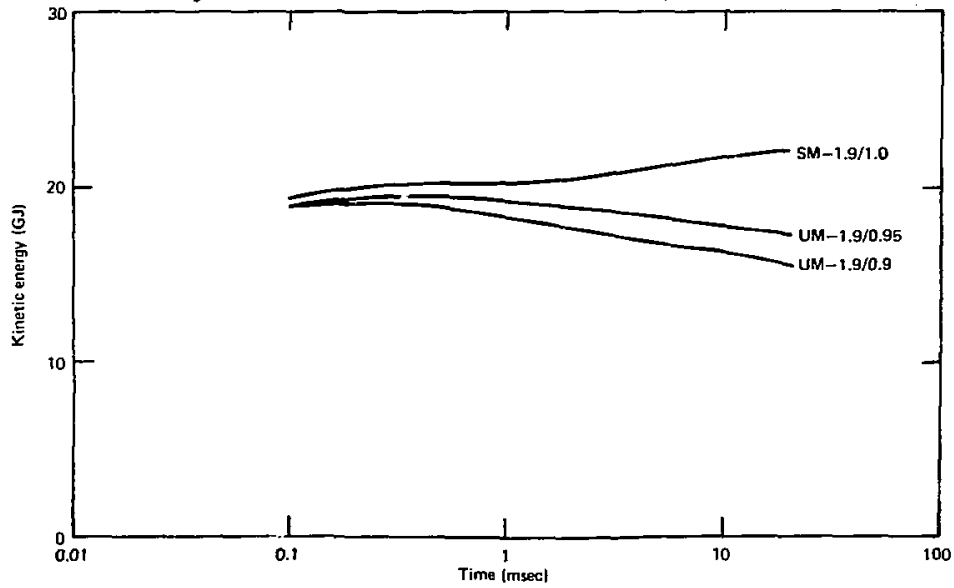

F1g. 58. Effect of gaturation on klnetlc energy coupling (uncemented soils, $\left.p_{0}=1.9 \mathrm{ig} / \mathrm{m}^{3}\right)$ 


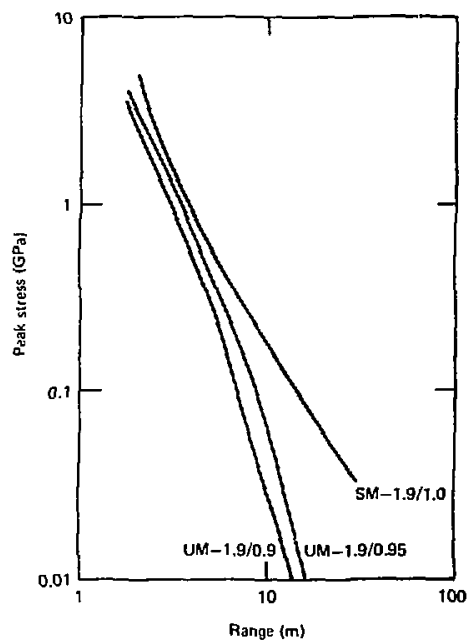

Fig. 59. Effect of sacuration on peik btress vs range (uncemented solla, $\left.\rho_{0}=1.9 \mathrm{Mg} / \mathrm{m}^{3}\right)$.

energy coupled Increasing almost twofold as $s_{w}$ goes from 0.8 to 1.0 . Furthermore, the effect of $S_{w}$ increases as $S_{w}$ approaches 1.0: the effect as $S_{w}$ goes from 0.95 to 1.0 is roughly the same as the effect as $S_{w}$ goes from 0.8 to 0.95 . Thus Increasing $S_{w}$ increases the coupled kinetic energy substantially, and it becomes particularly Important to know the value of $s_{w}$ if it is in the range from 0.95 co 1,0 .

Figures 56 and 57 show the effect of $\mathrm{s}_{\mathrm{w}}$ on peak stress versus range and peak particle velocity versus range, respectively, also for $p_{0}=1.7 \mathrm{Mg} / \mathrm{m}^{3}$. The peak stress, like the kiretic energy, is affected very stzongly by $S_{w}$, especially as $S_{w}$ goes from 0.95 to 1.0 . For examrle, et a range of $10 \mathrm{~m}$, the peak stress goes from $0.012 \mathrm{GPa}$ at $S_{w}=0.8$ to $0.05 \mathrm{GPa}$ at $S_{W}=0.95$, a fourfold tncrease. At $S_{w}=$ 1.0 , the peak stress is $0.17 \mathrm{GPa}$, an increase of more than threefold over 1 ts value at $S_{W}=0.95$. Beyond the 12- to 15II range for the unsaturated solls, the peak stress attenuates very rapidly. This is because the Fort Polk solls are so compressible at low stresses. The peak-particle-velocity plot, Fig. 57, Joes not show as great a varfation as is seen for the peak stress out to a range or about $11 \mathrm{~m}$. Beyond that range, the unsaturated solls $\left(0.8 \leq s_{w} \leq r .95\right)$ attenuate the peak particle velocity very rapidly.

Figures 58, 59, and 60 show the kinetic energy coupling versus time and peak stress

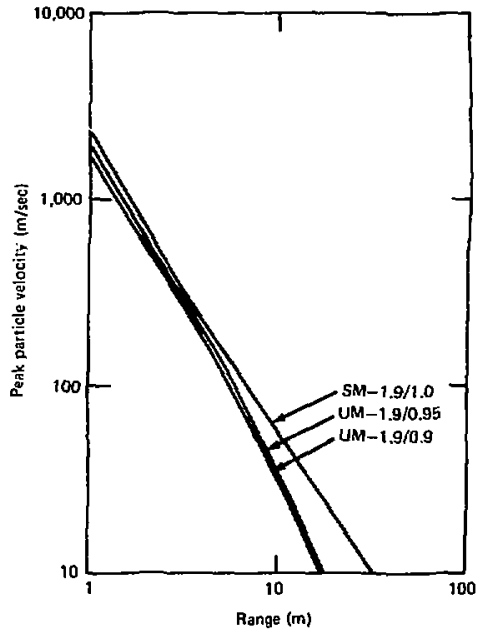

Fig. 60. Effect of saturation on peak particle velocity vo range (uncemented sctls, $\left.\mathrm{P}_{0}=1.9 \mathrm{Hg} / \mathrm{m}^{3}\right)$. 


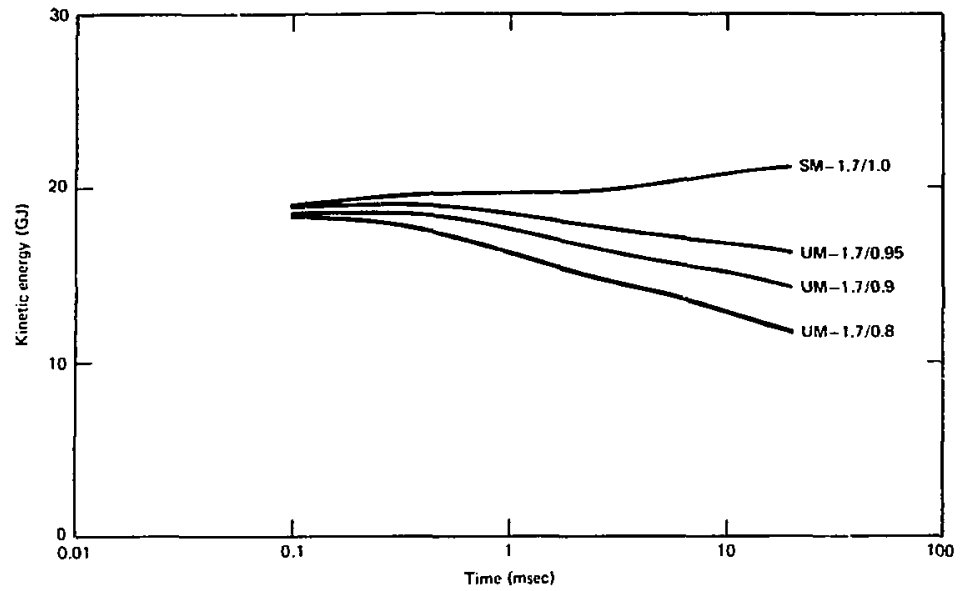

F1g. 61. Effect of saturation on kinetic energy coupling (uncemented solls, $\left.p_{0}=2.1 \mathrm{MB} / \mathrm{m}^{3}\right)$.

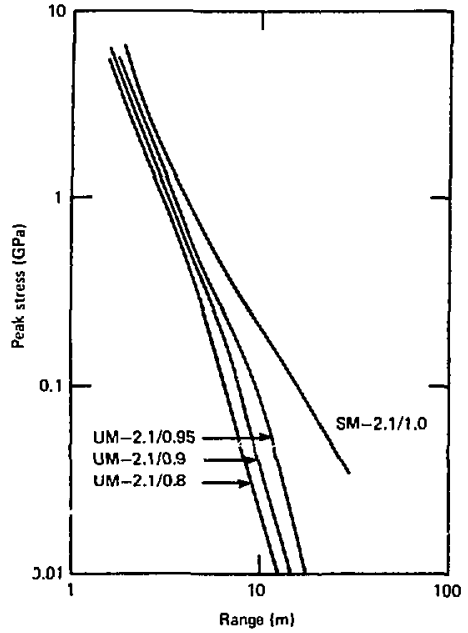

F1g. 62. Effect of saturation on peak atress vo range (uncemented solls, $\rho_{0}=2.1 \mathrm{Mg} / \mathrm{m}^{3}$ ).

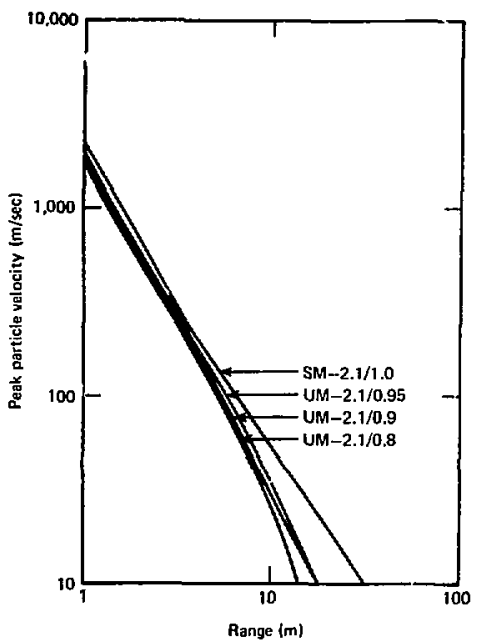

Fig. 63. Effect of saturation on peak particle velocity vs range (uncemented solls, $\left.P_{0}=2.1 \mathrm{Mg} / \mathrm{m}^{3}\right)$. 
(a)

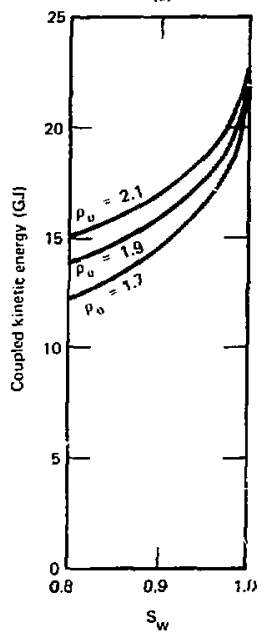

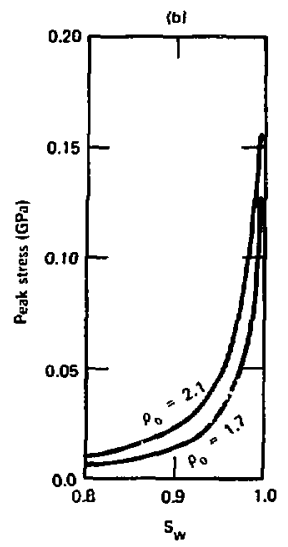

(c)

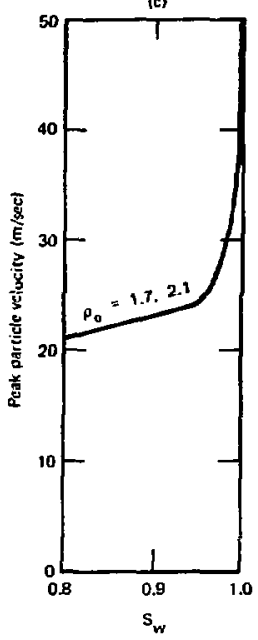

Fig. 64. Total effect of $S_{W}$ on kinetic energy coupling and ground motion.

and particle velocity versus range, respectively, for $\rho_{0}=1.9 \mathrm{Mg} / \mathrm{m}^{3} ; 11$ kewise Figs. 61,62 , and 63 show the same calculational results for $\rho_{0}=2.1 \mathrm{Mg} / \mathrm{m}^{3}$. The general trends found for the low-density solis are followed also for those at hIgher densities.

Figure 64 reviews the cotal effect of $s_{w}$ on kinetic energy coupling and ground motion for all three densitles considered. Thus the relative effect of both $?_{0}$ end $\mathrm{S}_{w}$ can be seen in Fig. 64a for coupled kinetic energy. Aa $S_{w}$ approaches 1.0, $\rho_{0}$ becomes relatively unimportant. Over :he relevant Fort Polk range $0.9 \leq$ $\left.s_{w} \leq 1,0\right), s_{w}$ seems to be the most critical factor in the determination of the coupled kinetic energy. For $S_{w}<0.9$, $\rho_{0}$ and $s_{w}$ are equally important. Figure $64 \mathrm{~b}$ show the peak stress at the 12-m range versus $S_{w}$. Again. In the relevant Fort Polk range for $S_{w}$, the quantity $s_{w}$ is clearly the critical factor in determinIng the peak stress. On the scale of the effect of $s_{w}$ an peak particle velocity (F1g. 64c) the determining factor is only $S_{w}$, and it is critical to know its value 1f 1 t les tetween 0.95 and 1.0 .

To summarize, then, $S_{W}$ has been found to be the nost important of the Independent bulk parameters constdered in the study. Increasing $S_{w}$ Increases both the strength of the ground moticn and the kinetic energy coupling, espectally as $S_{w}$ approaches 1.0. 


\section{Summary and Conclusions}

A calculational parameter study was performed to Investigate the sensitivity of ground motion and energy coupling 1riduced by a burled nuclear explosive to changes in the bulk properties of the emplacement medium. Of specific interest in the study were solls typical of the sites of the ESSEX I high-explosive-cratering experiments located at Fort Polk, Loula1ana. The calculations were one-dimensional and ut1lized a hypothetical 84-GJ (20-ton) nuclear source. Constitutive relations based on the bulk properties that were varled in the study were generated using a constitutive model developed during the course of the study. Output from this model 1g used directly as input to soc74, the computer code used in the study.

The bulk properties varied included the Initial bulk dengity $\rho_{0}$, the Initial bulk modulus $K$, and the initial water saturation $S_{w^{*}}$ An additional property, fallure, took Into account the shear strength of the soll. These properties, along with the grain density $\rho_{g}$ and Polsson's ratio (held constant throughout the study), made up an independent set fror which all other bulk properties could be calculated.

Results from 25 soc74 calculations were plotted, and the relative effect of the four Independent varlables was examlned.
It was found that, in the order of increasing importance, $k$, fallure, $\rho_{0}$, and $S_{w}$ affected both the ground motion and the couplitg of kinetic energy to the sol]. Furthermore, it was found that, for values of $s_{w}$ between 0.95 and 1.0 , the calculational results varied considerably, with a alight Increase in $S_{w}$ leading to much stronger ground totions and touch more efflctent energy coupling.

In a study of the cratering efficiency of explasions in various rock types by Terhune et al. ${ }^{16}$ it was concluded that the macerial propercles in order it decreasing Importance were water content, Ehear strength, porostity, and compressibility. Although the selection of Independent parameters in our soil study varied somewhat from thoge chosen by Terhune et al., the results from our study pruvide similar conclusions for the prescribed range of Fort Polk soll parameters. Water suturation is the most aensitive parameter. MaxImuth 3iear strength, which ranged from about 0.2 to $10 \mathrm{MPa}$ for the soils, is of less sigalficance for solls than it is for rocks. For solls, bulk ienstcy (porostey for a given grain densi,y) is a more Important parsmecer to cratering than is shear strength. Finally, the initial or low-pressure bulk modulus is the least sensitive parameter studled.

\section{Acknowledgements}

The authors wish to acknowledge the advice and suggestions provided by $\mathrm{H}, \mathrm{K}$.
Germain and J. S. Kahn of LLL during this Inveatigation. Major C. H. Carmean, Maj. 
L. C. Webster, Maj. A. E. M11 ?er, and Dr. T. E. Ricketts of the Explosive Excevation Division of the U.S. Army Engineer Waterways Experiment Station provided cechnical guldance and direction. Mr. J. Q. Ehrgott and Dr. J. S. Zelasko of the Sol1s and Payements Laboratory of the U.S. Arry EngIneer Waterways Experiment Station mate valuable technical and edttortal ouggestions. In additfon, the Explostre ExcavatIon DIvision and the SoIls and Pavements laboratory fielded the high-explosive cratering tests and gathered much of the experimental data in Project ESSEK which served as a basis for this study.

A spectal thank-yot goes to LInda Tripp, who prepared the In:tial manuscript $d B$ well as aeveral zevisions through the f1aal draft, to Lydis Burroi, who helped prepare the final draft, and to Wallace clements of the LLL Technical Information Department, who coordinated the production of the report. 


\section{References}

1. M. F. Goodrich and J. M. Thoosen, Progress Report on the FY75 Geolog1c Parameter Study, Lawrence Livermore Laboratory, Rept. UCON 75-23 (March 1975).*

2. M. F. Goodrich, J. M. Thomsen, J. B. Bryan, and C. M. Snell, Second Progress Report on the FY75 Geologic Parameter Study, Lawrence Livermore Laboratory, Rept. UCON 75-40 (June 1975).*

3. A. Miller, Parameter Study--Long hange Program, U.S. Army Eng Ineer Waterways Exper1ment Station, Explosive Excavation Research Laboratory, Livermore, Calif., Rept. WESEP-75-24 Apr11 10, 1975).

4. H. T. Harvey, ESSEX-DIAMOND ORE Research Program, Preliminary Report--ESSEX-I, Phase 1, U.S. Army Engineer Haterways Experiment Station, Explosive Excavation Research Laboratory, Livermore, Calif., Rept. WES PR-E-74-1, Defense Nuclear Agency Rept. DNA PR 0002 (1974).

5. A. E. Miller, ESSEX-DIAMOND ORE Research Program, Preliminary Combined Resules Repart, ESSEX-I, Plase 2, Nuclear Cratering Device SImulation (Project ESSEX), U.S. Army Englneex haterways Experiment Station, Explosive Excavation Research Laboratory, Livermore, Calif., Rept. EERL PR-E-75-1, Defense Nuclear Agency Rept. DNA PR 0016 (March 21, 1975).

6. J. Q. Ehrgatt and R. L. Stanley, ESSEX-DIAMOND ORE Research Prograa, Material Property Invest1gation for the ESSEX-I Test Site at Fort Polk, Loulsiana, U.S. Army Englneer Waterways Experiment Station, Vicksburg, Miss., Rept. WES-TR-S-75-3, Defense Nuclear Agency Rept. DNA PR 0014 (March 1975).

7. J. F. Schatz, The Physics of SOC and TENSOR, Lawrence Livermore Laboratory, Rept. UCRL-51532 (1973).

8. J. F. Schatz, SOC73, A One-D1mensional Wave Propagation Code for Rock Media, Lawrence Livermore Laboratory, Rept. UCRL-51689 (1974).

9. D. E. Burton and J. F. Schatz, Rock Mode11ng in TENSOR74, A Two-D1mensional Lagrang Ian Shock Propagation Code, Lawrence L1vermore Laboratory, Rept. UCID-16719 (March 19, 1975).

10. C. M. Snell and G. D. Mendez, User Information for Revised SoC74 Codes, Lawrence Llvermore Laboratory, Rept. UCID-16811 (March 10, 1975).

11. T. R. Butkovich, Effects of Water Saturation on Underground Nuclear Detonations, Lawrence Livermore Laboratory, Rept. UCRL-51110 (September 9, 1971).

12. B. K. Crowley, Effects of Porosity and Saturation on Shock-Wave Response in Tuffs, Lawrence IIvermore Laboratory, Rept. UCRL-74207 (September 14, 1972).

13. T. R. Butkovich, A Technique for Generating Pressure-Volume Relationships for Rocks, Lawrence Livermore Laboratory, Rept. UCRI-51441 (1973).

14. J. Q. Ehrgott, Revised Profile for 12MU Location--ESSEX I, Phase 2, letter of transmittal to A. E. Milier, from J. Q. Ehrgutt, of the U.S. Army EngIneer Waterways Experiment Station, Sc1ls and Pavements Laboratory (March 31, 1975).

"Internal document. Readers outaide the Laboratory who desire further information on LLT. Internal documents should address their Inquiries to the Teclinical Information Department, Lawrence Livermore Laboratory, Livermore, CA 94550. 
15. C. E. Chapin and T. R. Butkovich, private communication, "Radiation Correction of Equation of State Tables Used in the SOC and TENSOR Computer Codes," YOPKA 69-34, memorandum, Lawrence Lfvermore Laboratory (June i969).*

16. R. W. Terhune, T. F. Stubbs, and J. T. Cherry, "Nuclear Cratering from a Digital Computer," Peaceful Nuclear Explosions, 1970, 415-440. 


\section{Appendix}

\section{Compreaibility of Hypothetical Materials}

Compresstbllity was calculated for each hypothetical material uaing the model described under "Constitutue Model for Sol1s." The inputs for this model were the Independent bulk properties plus the merge and transition pressures assoclated with the particular faflure model used. Values for the Independent bulk parameters and the fallure model used can be obtalned directly from the name listed ac the top of each table, as diacussed under "Bulk Property and Constitutive-Relarton Input for Individual Calculations," while values of $P_{T}$ and $P_{M}$ are taken from Table ?. All compressfbilftes for hypothetical materfals were derived assuming a mixture of 25 wt clay and 75 wt: sand. The following tables liat the P-y data exactly as Input to the soc7s code, for all 25 hypothetical solls or weak rocks used in the study. Since the $50 \mathrm{c} 4 \mathrm{pro-}$ gram uses pressures (P) in megabar units and volumes (v) In cublc centimeter units, the actual tables are in those units. The quantftes "EF" and "EV" are the calculated specific energies required to melt and vaporize the hypothetical soll, reapectively. 
Table Al. Coordinated fallure mode1, Un - 1.7/0.80 (F1g. 8).

Input variables

$$
\begin{aligned}
& p_{0}=1.7 \mathrm{Mg}_{B} \mathrm{~m}^{3} \\
& P_{T}=100 \mathrm{kPa}
\end{aligned}
$$

$$
\begin{aligned}
& z=0.2441 \\
& e_{-}=0.8622
\end{aligned}
$$

$$
\begin{aligned}
& S_{W}=0.80 \\
& P_{M}=10.4 \mathrm{MPa}
\end{aligned}
$$

Output

$$
\begin{aligned}
& \phi_{0}=0.5187 \\
& \mathrm{EP}=5.471 \mathrm{~kJ}
\end{aligned}
$$<smiles></smiles>

$$
\begin{aligned}
& \Phi_{a}=0.1037 \\
& E V=30.57 \mathrm{~kJ}
\end{aligned}
$$

\section{LQ:IIIIL PATH}

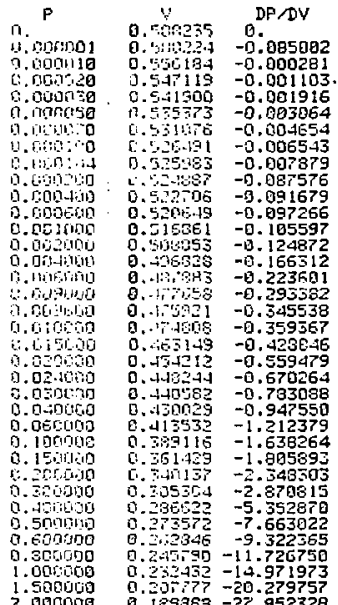

e.

$\mathrm{MJ}$

0.090020

0.05762?

0.075150

0.085505

0.098739

อ. 107629

อ. 117275

0.118354

อ. $1 \geq 9689$

0.125366

B. 129811

0. 158691

อ. 156902

0.183983

0.205689

0.231500

0.235993

0.238391

0.279978

0.295068

0.312310

B. 335132

0. 367898

0.422466

0.511 .22

0.627527

0.7294a?

0.926722

1.052303

i. 150200

1.237951

1.393239

1.530782

1.031099

2.69777?
DP/DMU

0.

0. 050000

ด. 009156

0.000571

0.000966

0.001511

ด. 002250

0.003110

0.003709

0.941163

0.042761

0.045000

ด. 948308

0.055832

0.071478

0.992139

0.116229

0. 133536

0.138051

ด. 160321

0.200084

0.231989

0.262906

0.305194

0.36651 ?

0.448148

0.431761

0.499772

0.506804

0.796301

1.02 1483

1. 139580

1.287930

1. 454983

1.654967

i. 674945

: RTINING PHTH

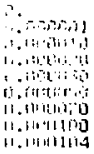

$$
\begin{aligned}
& \text { ก. } \because 10 \\
& \therefore \because-8 \\
& \text { 1. . }, \because 64 \\
& \text { 1.. } \because 41 \\
& r_{1} \therefore 1 . \\
& 11 \therefore+1.19 \\
& 11.4 .1, \mathrm{At} \\
& \text { (1. ' at il } \\
& \text { 0.'.". }
\end{aligned}
$$

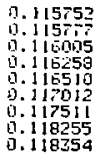

a.

0.039392

0. 039448

0.039556

0.039659

0.039839

0.040565

0.040348

B. 040541 
Table A2, Coordinated fallure rodel, IM - 1.7/0.90 (F1g. 8).

\section{Input yartables}

$$
\begin{aligned}
& \rho_{0}=1.70 \mathrm{Mg} / \mathrm{m}^{3} \\
& P_{T}=100 \mathrm{kPa}
\end{aligned}
$$

$$
\begin{aligned}
& z=0.2901 \\
& e_{w}=1.091
\end{aligned}
$$

$$
\begin{aligned}
& S_{w}=0.90 \\
& P_{M}=10.4 \mathrm{MPa}
\end{aligned}
$$

\section{Output}

$$
\phi_{0}=0.5480
$$$$
E F=\$ 5.938 \mathrm{~kJ} / \mathrm{cm}^{3}
$$

$\mathbf{K}=5.0 \mathrm{GPa}$

$$
\phi_{\text {a }}=0.0548
$$

$\mathrm{EV}=31.773 \mathrm{~kJ}$ m

0.000020

9. 929006

0.037924

0. 0.13251

0.050168

0.054691

0.060139

0.050734

0. 063287

0.068160

0.072869

0.981644

0.100634

ด. 130295

9. 153266

0. i 30466

0.165209

0.188253

0.220852

0.246721

0.261418

0.287636

0.329548

0.374393

0. 459856

$0.5 \div \geq 346$

0.669353

0. 857575

0.981156

1.079758

1. 168992

1.168992
1.328936

1.472814

1.794316

2.088445
DP $/ D F$

ด. 050000

0.000310

อ. 001121

Q. 06187?

ด. 002895

0.004227

0.005717

0.006r 19

0. 038821

0.040576

$0.0424 \vec{a}$

0.045534

0.052659

0.06? 427

ด. $06^{\circ} \div 67$

b. I ILII6

Q. 12702

a. 131434

0. 153376

0. 193390

0. 226028

0. 258424

0. 303833

e. 372059

0. 467549

0. 4444e3

0. 512260

0.532985

0.209183

1. 014183

1. 120644

I. 250444

1.390061

1.555199

1.599939

\section{III, IISING PATH}

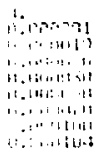
A. cripan
1., $\therefore$, 13
i1. '
11. ', 1,19
n. $\therefore \cdots$

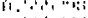
11.
I: $\because 1 .+1,11$
11. $\cdots$

ก. 95.960

i. ivantio

i. 650.12

11.145016

iingin?

1. $1959-1-1$

$11,1,1 \%: 17$

11. 16 Lic 29

$0.060 \div 54$

0 .

0. 053216

0.05-359

0.03iso

a. $1 \vec{B} \vec{i}+\overrightarrow{6}$

ด. 137636

0,03784

0.020113

ด. 039293 
Table A3. Coordinatec fallure model, UM - 1.7/0.95 (FIg. 8).

\section{Input vartables}

$$
\begin{aligned}
& \rho_{0}=1.7 \mathrm{Mg} / \mathrm{m}^{3} \\
& P_{T}=100 \mathrm{kPa}
\end{aligned}
$$

$$
\begin{aligned}
& z=0.3152 \\
& e_{w}=1.2287
\end{aligned}
$$

$$
\begin{aligned}
S_{H} & =0.95 \\
P_{H} & =10.4 \mathrm{MPa} \\
\text { Dueput } & \\
\phi_{O} & =0.5640 \\
E F & =6.243 \mathrm{~kJ}
\end{aligned}
$$

\begin{tabular}{|c|c|}
\hline 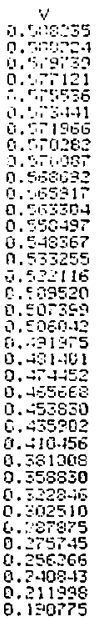 & 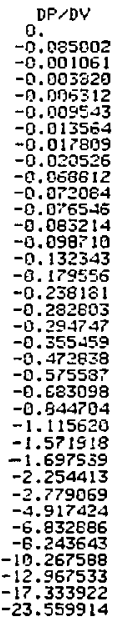 \\
\hline
\end{tabular}

$K=5.0 \mathrm{GPa}$

$t_{3}=0.0282$

$E V=32,490 \mathrm{~kJ}$

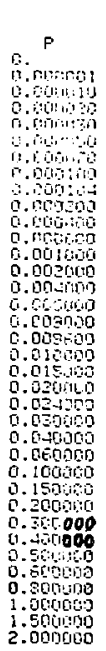

1. DNIIING PATH
$M J$

0.000020

0.014656

0.019259

0.022064

$0.0258[\mathrm{~J}]$

0.028444

0.051482

0.031635

6. 934366

0.059437

0.044258

0.053246

Q.072704

0.103104

อ. 126537

อ. 154480

0.159315

0. 162424

0. 195650

0.221924

0.239822

0.263207

0.296159

0.345466

0. 433127

0.543891

0.639317

a. 822029

0.944512

1. 043368

1. 133260

1. 295409

1.442403

1.774725

2.083395

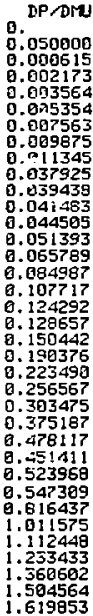

\section{IHALLIHIIIAG PATH}

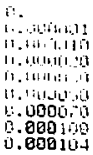

$$
\begin{aligned}
& \text { ग1. } 11.0 \\
& \text { 11 } 110 \\
& \text { 11. } 1 \text { 1 } 1 \text {. } \\
& \text { 1., . 1 16? } \\
& \text { i. . 19: } \\
& \text { 11. } 11051 \\
& \text { ‥ } 5 \text {. }
\end{aligned}
$$

$\begin{array}{ll}0.029016 & 0.0 \\ 0.029043 & 0.036365 \\ 0.039290 & 0.030416 \\ 0.029564 & 0.036514 \\ 0.029637 & 0.036518 \\ 0.030381 & 0.036773 \\ 0.030922 & 0.036979 \\ 0.031728 & 0.037237 \\ 0.031835 & -037413\end{array}$


Table A4. Coordinated fallure model, SM - 1.7/1.0 (EIg. 7).

\section{Input varlebles}

$$
\begin{aligned}
& P_{0}=1.7 \mathrm{Mg} / \mathrm{m}^{3} \\
& P_{\mathrm{T}}=10 \mathrm{kPa}
\end{aligned}
$$

$$
\begin{aligned}
& z=0.3417 \\
& e_{w}=1.3857
\end{aligned}
$$

$$
\begin{aligned}
& s_{W}=1.0 \\
& P_{H}=311 \mathrm{kPa}
\end{aligned}
$$

Output

$$
\begin{aligned}
& \phi_{0}=0.5808 \\
& E F=6.612 \mathrm{~kJ}
\end{aligned}
$$

$$
\mathrm{K}=5.0 \mathrm{GPa}
$$

$$
\begin{aligned}
& \phi_{\mathrm{a}}=0 . \\
& \mathrm{BV}=33.304 \mathrm{~kJ}
\end{aligned}
$$

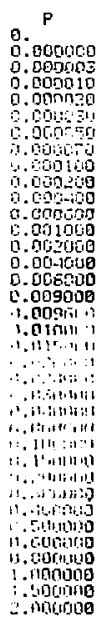

อ.
0.0000日月
LOAIING PATH

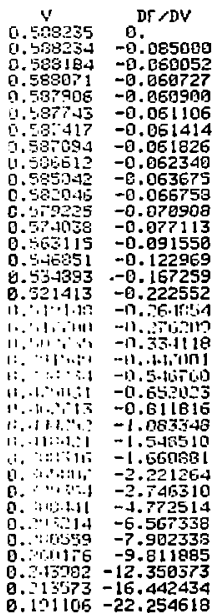

0.

0.

9.000002

ด. 000087

0. 009280

0.000560

0.003839

อ. 001393

0.001945

0.002767

0.005459

ด. 019634

0.015555

0.024732

0.044609

D. 075678

b. 099724

0.128155

0.133078

0.1362 .18

0.170070

0. 1 gega6

0.214776

0.238308

0.271274

0.324102

0.405846

0.514835

0.698050

0. 785810

0.987 125

1.006164

1. 096551

1. 269913

1.410976

1.754258

DP,DH

Q.

0. อ5อยด

e. 035322

0.035?日9

0.035794

0.035894

0.036046

a.036247

0.056498

0.037.150

0.038646

0.048549

0.043508

0.050309

0.0643?4

0.0631?1

0. 105519

อ. 121879

ด. 126199

อ. 147831

ब. $1 \mathrm{~B}>786$

0.221242

0.254979

0.303348

0.378581

0.469335

0.458761

0.536397

0.562556

0.02429 ?

1. 009706

1.105132

1.217569

1.332767

1. 456531

$2.078061 \quad 1.544150$

\section{UHLOADING PATI}

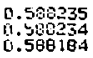

\section{808000 B. 609003 \\ D. อ.}


Table A5. Coortinated fallure model, UH - 1.9/0.90 (PIg. 8).

Input variables

$$
\begin{aligned}
& \rho_{0}=1.90 \mathrm{Mg} / \mathrm{m}^{3} \\
& P_{T}=100 \mathrm{kPa}
\end{aligned}
$$

$$
\begin{aligned}
& z=0.2061 \\
& e_{y}=0.6930
\end{aligned}
$$

$$
\begin{aligned}
& S_{W}=0.90 \\
& P_{M}=10.4 \mathrm{kPa}
\end{aligned}
$$

Output

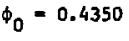

$\mathrm{EF}=7.297 \mathrm{~kJ}$
$\mathrm{R}-5.0 \mathrm{GPa}$

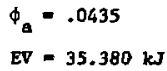

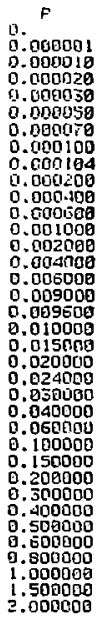

$\mathrm{V}$

D.Sํ.5316

0.526305

0.51-1605

Q.51110a

0. 519041

0. 506385

อ. 504582

0.502597

0.502372

0.501436

0.429572

0. 195814

0.49451

0.487700

0.477326

0. 46955 r

0.460600

0. 459069

b. 45808 ?

0.447717

0.453656

0. $43 \pm 214$

0. 427152

0.417287

0.4 1556

0. 377692

o. 350947

0. 330130

อ. 295912

0.275110

0.265915

$0.255940-10.024623$

0.2-10182 - 12.692395

9. $22730-16.322694$

0. $205518-22.309494$

$0.169415-31.051536$ o.

B. ต0ย920

0.022756

0. 029754

Q. 033935

0.039358

Q. 043073

9.047193

B. 04766j

0.049616

อ. 053533

0.057254

0.064385

D.079180

D. 102633

B. 120978

0.142675

6. 146494

Q. 149943

ด. 175556

0.197107

0.212112

0.232150

0.261281

0.310690

ด. 393596

0.499701

0.594269

ด. 778621

0.89243

0.97926

1.056404

1. 191317

1.329116

1.560929

1.776634
DP DND

0.050008

D. $00 \mathrm{Bg}$

0.001429

0.002392

0.91368

0.005384

0.007281

B. 098556

0.049081

0.051067

0.053749

0.057707

0.066689

0.085279

0.109615

9. 137636

0. 157528

0.1626月2

0.187877

0.232003

0.266593

0.299427

0.343278

0.494782

b. 483800

0.470931

0.528721

0.542439

0.878662

1. 151677

1.296292

1. 482437

1.697803

1.985695

2.296501

\section{UHLOADIHG PATH}

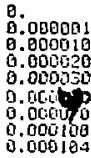

0.593420
0.503469
0.50 .5317
0.505215
0.503114
0.502912
0.502111
8.502412
0.502372

0.045481
0.045503
0.045594
0.045905
0.045117
0.046537
0.045955
0.047578
0.047661

0.

0. 047830

0. 947096

0. 947227

0.047363

0.947566

0.847831

0.049177

0. 948497 
Table A6. Coordinated fallure model, UN - 1.9/0.95 (Fig. 8).

Input variables

$$
\begin{aligned}
& \rho_{0}=1.9 \mathrm{Mg} / \mathrm{m}^{3} \\
& P_{\mathrm{T}}=100 \mathrm{kPa}
\end{aligned}
$$

$$
\begin{aligned}
& z=0.2238 \\
& e_{w}=0.7700
\end{aligned}
$$

$$
\begin{aligned}
& S_{\mathrm{w}}=0.95 \\
& P_{\mathrm{M}}=10.4 \mathrm{MPa}
\end{aligned}
$$

Output

\begin{tabular}{|c|c|}
\hline 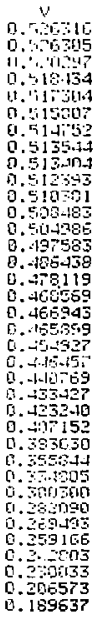 & 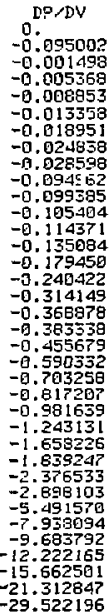 \\
\hline
\end{tabular}

$$
\begin{aligned}
& \phi_{0}=0.4477 \\
& \mathrm{EF}=7.485 \mathrm{~kJ}
\end{aligned}
$$

$\mathrm{X}=5.0 \mathrm{GPa}$

$$
\phi_{\mathrm{a}}=0.0224
$$

$E V=36.063 \mathrm{~kJ}$

\section{LQAI ING PATH}

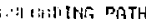

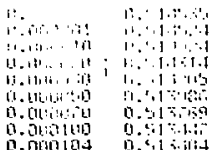

M

B.00gazo

0.011569

0.015204

ด. 117420

0. 020373

ต. 022466

0. 024870

0.025149

0. 027172

घ. 0.1222

0.035070

0.042239

0.057745

ด. 981930

0.100805

0.123248

D. 127152

0.129677

0.156924

B. ? Pe日72

0.194085

0.214312

0.243548

0. 292677

0.374087

0.479061

0.572065

0.75 3633

0.865770

0.952986

1.030803

1. 167689

1.287998

1.547341

1. 775388
0.

DP DMU

B.050日a

0.009779

0.002751

0.004511

0.006772

0.009560

0.0.12475

0.034326

D. 047464

B. 049382

0.051974

0.055799

0.054491

B. 082526

0.106241

B. 13372

0.153347

0.158450

0.183504

B. 227809

0.262941

0.296528

0.342144

B. 407018

0.491344

0. 476305

0.537960

B. 553625

B. 68388

1. 146583

1.285065

1. 401291

1.662106

1. 924243

2. 197349
17, 17.29

11.112.18

1. . 128116

0.12353

0.023553

0.023988

0.024420

0.025064

0.025149
0.

0. 045484

0. 045549

0. 045674

0.045895

ต. 046002

0.046254

0.046591

0.046813 
Table A7. Coordinated fallure model, SM - 1.9/1.0 (FIg. 7).

Input vartables

$$
\begin{aligned}
& \rho_{0}=1.9 \mathrm{~kg} / \mathrm{m}^{3} \\
& P_{T}=10 \mathrm{kPa}
\end{aligned}
$$

$$
\begin{aligned}
& z=0.2427 \\
& E_{w}=0.8556
\end{aligned}
$$

$$
\begin{aligned}
& s_{w}=1.0 \\
& P_{M}=311 \mathrm{kPa}
\end{aligned}
$$

\section{Output}

$\Phi_{0}=0.4611$

\begin{tabular}{|c|c|c|}
\hline & 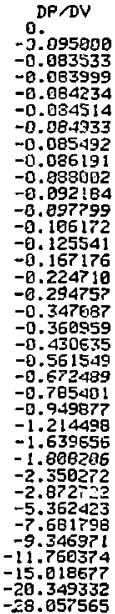 & 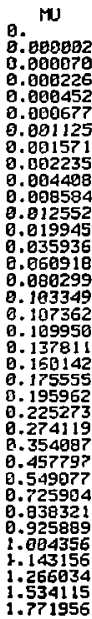 \\
\hline
\end{tabular}

$\mathrm{EF}=7.706 \mathrm{~kJ}$
$\mathrm{K}=5.0 \mathrm{GPa}$

$$
\begin{aligned}
& \phi_{E}=0 . \\
& E V=36.832 \mathrm{~kJ}
\end{aligned}
$$

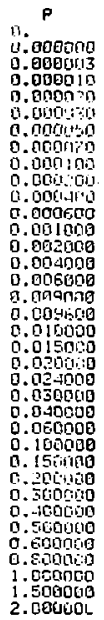

LURIIING PATH

DP

0. 050000

0.043962

0.044197

0.044304

a. 044431

0.044621

g. 044875

0.045191

0.046011

0.047894

8.050402

0.054108

0.062535

0.68005日

0.103191

0. 139153

0. 149514

0. 154565

a. 179466

6. 223899

0.259524

Q.294021

0.341164

B. 409450

0.500199

0.492115

0.547765

0.565523

0.889548

1. 141976

1. 274416

1. 449917

$1.62763 \mathrm{~B}$

1. 865106

\section{UILLOA ING PATH}
0.
0.000050
0.526316
$3.0000 \mathrm{~b}$

0.
0.090902
0.000070

0.

0.044114

0. 644134 
Table A8. Coordinated fallure modeI, UM -2.110 .80 (FIg. 8).

Input variables

$$
\begin{aligned}
& \rho_{\mathrm{O}}=2.1 \mathrm{Mg} / \mathrm{m}^{3} \\
& \mathrm{P}_{\mathrm{T}}=100 \mathrm{kPa}
\end{aligned}
$$

$$
\begin{aligned}
& z=0.1161 \\
& e_{w}=0.3508
\end{aligned}
$$

$$
\begin{aligned}
& S_{W}=0.80 \\
& P_{H}=10.4 \mathrm{HPa}
\end{aligned}
$$

Output

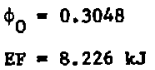

$\mathrm{K}=5.0 \mathrm{GPa}$

$$
\begin{aligned}
& \Phi_{a}=0.0610 \\
& E V=37.99 \mathrm{~kJ}
\end{aligned}
$$

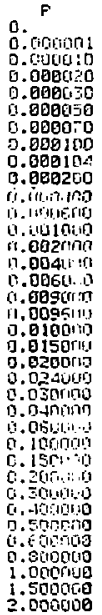

0. $\stackrel{1}{2}$ 0. 4.9139 0.46151 0.451279 0.456927 0.454394 0.451196 0.449073 0. +46.91 0.44653 0.445980 0..+3.106 $0,4.13915$ 0.1-il361 (t. $A$ तु 6 ? 0.151210 $0 .-126.318$ 13. t.30261 0.119212 0. - $118.5: 45$ 1...111232 $0 . .105335$ 0.0101036 0.395594 ก. $\operatorname{sat} 155$ 1. $275=25$ 19. Scoso 0.336160 1:. 316.165

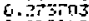
$0,-250$

$0.2-7000$ 0.23010 - 12.197490 0.220921 - 15.761653 0.217202 -20.74945日 $0.20017-29.227079$ $0.700174-29.227079$
$0.168294-42.066405$ DP/DV G. $-0.105002$ $-0.090604$ $-0.002298$ $-0.003947$ $-0.006254$ $-0.009420$ $-0.013150$ $-0.015773$ $-0.172121$ -D. $17964 a$ $-0.189225$ $-0.204852$ $-0.238958$ $-0.309336$ $-0.400621$ $-0.5036 .14$ -0.5755:6 $-0.593924$ $-0.682765$ -0.63513日 $-0.952483$ $-1.063509$ $-1.213749$ $-1.436864$ $-1.773069$ $-2.039471$ $-2.538763$ $-3.052330$ $-3.052330$ $-6.3637$ a.

0.000020

0. 032326

0.042158

0.047969

0.055396

0.060386

0.065808

0.065406

0. 957739

0.070411

0.072952

0.077694

0.087998

0. 104311

0.117246

0. 133061

0. 135899

0.137727

0. 157908

$0.17509 ?$

0.187402

0.204344

0.229974

0.275844

0.357921

อ. 459991

0.553816

0.739605

0.84568 ?

0.921611

0.987368

1. 19158

1.378879

1. 528974
1.
DPAN

050009

0.608279

0.001017

0.001721

0.002693

0.005541

0.006608

0.071983

0,074449

0.078705

0.084362

ด.997846

0.122600

ด. 169450

0. 212930

0.219843

0.246780

3.292252

0.325062

0. 354138

0.390178

0.436017

D. 487343

0.489862

0.532909

0.537665

0.944446

1.317108

1.520939

i.799695

2. 148435

3.669538
$0.00408 \mathrm{~B}$

0.154623

IHILOADING PATH
0.
C. cootio!
1. cosid
1. $\therefore 7=0$
0.500500
9.0090150
ก. conger
0.000100
o. ocioidas

0.064920
0.064935
0.065055
0.065209
0.065353
0.065649
0.065925
0.066349
0.066496

0.

0. 069013

0.06911

0.069298

0.069495

0.669790

0.670184

Q. 079674

0.071009 
Table A9. Coordinated fallure model, OH $-2.1 / 0.90$ (F1g. 8).

Input variables

$$
\begin{aligned}
& \rho_{0}=2.1 \mathrm{~kg} / \mathrm{m}^{3} \\
& P_{T}=100 \mathrm{kPa}
\end{aligned}
$$

$$
\begin{aligned}
& z=0.1380 \\
& e_{w}=0.4275
\end{aligned}
$$

$$
\begin{aligned}
& S_{w}=0.90 \\
& P_{N}=10.4 \mathrm{MPa}
\end{aligned}
$$

Qutput

$$
\begin{aligned}
& \phi_{0}=0.3220 \\
& \mathrm{EF}-8.551 \mathrm{~kJ}
\end{aligned}
$$

$\mathrm{K}=5.0 \mathrm{GPa}$

$$
\begin{aligned}
& \phi_{a}=0.0322 \\
& E v=39.038 \mathrm{~kJ}
\end{aligned}
$$

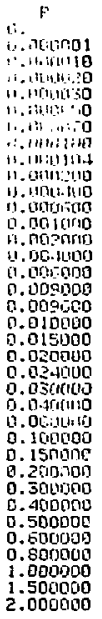

C.

c. 1.2019

11. 11,4150

1!. It. Iill.1.9

1i. - listing

i. . itions.

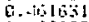

o. lin)

[i. 11 त 129

D..15า.130

อ. 173184

0. +56358

$0 . .154692$

อ. 4.1955

0. 442456

ต. 436760

0. 4 360

0.426930

0. 42817

0.420106

0. +13614

ด. 409112

4. 405125

B. 394.190

0.350130

0.357252

0.332194

0.312226

0.279110

0. 262898

0. 252216

$0.2+3585$

D. $230 \pm 49$

Q. 219874

0. 203567

UNLOADING PATH

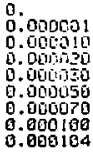

0.

ด.008020

0.016653

0.021777

0. 024839

อ. 028814

9.031530

0.034562

0.034905

0.036369

0.039301

0.042087

9.047202

0.05854

0.075292

0.990260

0. 107212

0.110209

0.112151

0.133501

0.15129:

0. 163961

D. 181248

0.207105

0.252705

D. 332925

a. 433472

0.525148

0.706106

0.811312

0.888028

0.954927

1.069055

1. 165746

1. 363522

1.525313
0.

DPAM

B.050900

0.000541

B. 001952

0.003265

0.00503

0.007341

0.099921

0.011653

0.065596

0.060224

0.0717>7

0.077001

Q. 886768

0.112710

0.143162

0.176976

0.200157

0.206049

0.234187

0.281049

0.315722

Q.34707 1

0.396755

0.438590

0.498633

0.497277

0.545402

0.552614

0. 950516

1. 303500

1. 494794

1. 752425

2.068443

2.528115

3.090495
0.033275

0.033291

日. 033434

0.033592

0. 933750

0.034965

0.034378

0. 034844

0.034905
9.

0.062858 0.062948 0.ก63:20 0.063301 0.063572 0.953933 0.064394 
Table Al0. Coordinated fallure model, UM - 2.1/0.95 (FIg. 8).

Input variables

$$
\begin{aligned}
& \rho_{0}=2.1 \mathrm{Mg} / \mathrm{m}^{3} \\
& P_{T}=100 \mathrm{kPa}
\end{aligned}
$$

$$
\begin{array}{r}
z=0.1499 \\
e_{w}=0.4709
\end{array}
$$

$$
\begin{aligned}
& S_{W}=0.95 \\
& P_{Y}=10.4 \mathrm{MPa}
\end{aligned}
$$

Output

$$
\begin{aligned}
& \phi_{0}=0.3314 \\
& E F=8.749 \mathrm{~kJ}
\end{aligned}
$$

$K=5.0 \mathrm{GPa}$

$$
\begin{aligned}
& \phi_{a}=0.0166 \\
& E V=39.645 \mathrm{~kJ}
\end{aligned}
$$

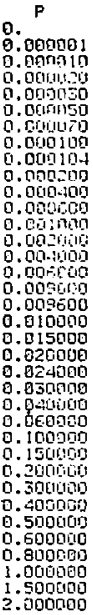

$\mathrm{V}$

0. 476190

0.476181

ด. 4 P IES

0,1 .

6.170157

9.469.

$[, .153432$

0. $.11,-513$

$0 .-10.518$

0.-4อ6อ18

$0 .-155+23$

0. $46+104$

0. 461667

0.45342

$0.4+8539$

0. $4 .+2503$

0. $.55+19$

0.434193

0.453403

0.424935

0.418159

0.4 i 3593

0.497327

0.590472

0.383377

0. 30.0327

0. $355-174$

0.315357

$0.2 \mathrm{~B} 2 \mathrm{n}+\mathrm{B}$

0.255560

G. $25+1512$

$-0.06804$

$0.245745-11.278676$

$0.231904-14.448679$

0. $221255-10.930524$

0.202182

$-10.930524$

G. $108715-37.128547$ a.

$-0.105002$

-0.0p2?43

$-0.013150$

$-0.019793$

$-0.036508$

$-0.042084$

$-0.143336$

$-0.151703$

$-0.164115$

0.19251

$-0.331347$

$-0.423493$

0.48 .483

-0. 590442

0.738981

$-0.857172$

$-1.123921$

$-1.369890$

$-1.735350$

$-1.572110$

$-2.485527$

$-3.002201$

$-6.06480$

0. 000820

0.008518

ด. 011197

0.012833

0.015014

0.016562

9.018343

0.010550

0.020077

0.023135

0.026042

0.031459

0.043197

0.061649

0. 076130

B. $09363 \mathrm{~B}$

0. 096726

0.098724

0. 120619

0. 138751

0. 151602

อ. 169061

ด. 195026

0.240476

0.319718

0. 41945 ?

0.510003

0.680329

0.79315 ?

0.970260

0.337737

1. 053397

1. 151956

1.355256

1.523327
DP/DH

0.05000

ด. 181059

ด. ค0 3732

0.006!14

0.009168

0.012923

0.016839

Q.019321

0.062860

0.065396

ต. 068014

0.073844

0.035196

0. 108389

0. 139108

อ. 171352

0.194333

0.209199

0.228356

0.275757

0.311255

0.343669

0.385136

0. 449946

$0.50477 \mathrm{~B}$

0.501312

0.552204

$0.5607 \div 1$

0. 953942

1.296959

1.462605

1. 729196

2.029256

2.459414

2.974931

\section{UNEOADING PATH}

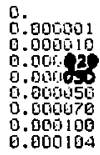

0.408300
0.463292
0.468224
0.45148
0.4165072
0.409921
0.46777
0.407547
6.467510

0.016949
9.016866
9.017015
0.017100
0.017345
0.017673
0.019000
.019496
0.018550

0

0.06023日

0.060325

0.060490

0.060664

0.069924

0.061271

0.061705 
Table A11. Coordinated fallure mode1, SM - 2.1/1.0 (F18.7).

Input variablea

$$
\begin{aligned}
& \rho_{0}=2.1 \mathrm{Mg} / \mathrm{m}^{3} \\
& P_{T}=10 \mathrm{kPa}
\end{aligned}
$$

$$
\begin{aligned}
& z=0.1625 \\
& E_{y}=0.5187 .
\end{aligned}
$$

$s_{w}=1.0$

$\mathbf{P}_{\mathbf{M}}=311 \mathrm{kPa}$

Output

$$
\begin{aligned}
& \phi_{0}=0.3413 \\
& E F=8.926 \mathrm{~kJ}
\end{aligned}
$$

\begin{tabular}{|c|c|c|}
\hline & $\mid i \|_{1} b_{1}$ & $\mathrm{H}_{\mathrm{A}} \mathrm{FH} \mathrm{FH}$ \\
\hline , & 1. & {$[P, D V$} \\
\hline ר. . . . & $1, \ldots$ in $1 \cdot 1111$ & 1). \\
\hline$\ldots$ & $\because 1,1,1, \ldots$, & 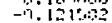 \\
\hline$\therefore: 1 ., 1$ & 1:, $1,1, t \in 1:$ ? & 12177 \\
\hline 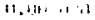 & $11,-1,111, \because$ & 122109 \\
\hline 10.18t & $1.1 .1+1,+1.15$ & 122553 \\
\hline \$ & 0.115782 & 123092 \\
\hline 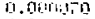 & $0.4,+21$ & 123879 \\
\hline 1]. 61,1610 & $0.1 .5 \mathrm{5} 3$ & 24862 \\
\hline $0.00+1,210$ & 1. $-4,16,35$ & 127403 \\
\hline 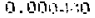 & a.,., 20195 & 133273 \\
\hline 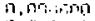 & ค. 41613 & 141124 \\
\hline $0.0101+2181$ & $\because,+4159$ & $15 \geq 775$ \\
\hline $0.061 . ; 1,117$ & $6 . .4 .5 .188$ & 179469 \\
\hline $0.0\left[1, d t^{6}+6\right]$ & $11,-15,50106$ & -0.235738 \\
\hline 0.00 . & $19 .+10531$ & 511258 \\
\hline $9.919+190$ & 1. .111076 & $3996-18$ \\
\hline 0.000010 & $0 .+139732$ & 63615 \\
\hline 0.010 na & 0. 430749 & 480250 \\
\hline 0.0150170 & 0.450153 & 562074 \\
\hline $0.920,160$ & 23946 & 08533 \\
\hline n.0. & 0.418156 & $\begin{array}{l}-0.826309 \\
-0.941372\end{array}$ \\
\hline $0 .[1+4,11+10]$ & a.. . 17003 & 1.101525 \\
\hline G. 12 ana 1000 & 0.7 .49 & 46.453 \\
\hline 0.1601150 & 0.35 .4516 & 121694 \\
\hline 0.15 binge & [. 339950 & 48095 \\
\hline 0 & 0. 316076 & \\
\hline 1). $309(11 \%)$ & 5.35163 & 383910 \\
\hline 3.400050 & 60581 & \\
\hline 3.500and & Q.5. 5151 & -8.905133 \\
\hline 0.6000ij0 & a. 닌 & 10.979493 \\
\hline 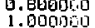 & Q.323764 & $\begin{array}{l}213109 \\
202303\end{array}$ \\
\hline t. $5090 \mathrm{n}$ & Q. $20 \geq 351$ & 95779 \\
\hline 2.000000 & 0.138873 & 64769 \\
\hline
\end{tabular}

$K=5.0 \mathrm{GPa}$

$\phi_{a}=0$.

$E V=40.318 \mathrm{~kJ}$
GRLEDIHG PAT in

0.0 nogar

0.0uncosa

0.908173

0.000545

0.000516

0.000058

0.001198

0.001704

0.003361

B. 006543

อ. 00956?

0.015203

c. 027406

9.046558

0.061549

0.079511

0.682789

0. 084843

อ. 107282

0.125755

อ. 136797

0.156416

a. 182495

a. 227772

ด. 306005

0.404898

0. 494277

0.669888

0.774309

0.851791

0.919844

1. 037069

1.137531

1. 346559

1.521227
[IP PMU]

$\theta$.

0. 150050

D.05i 893

0. 05.976

0.058117

0.058284

0.058535

0.058969

0.059286

0.050365

0.062840

6.066132

0.07098

0.081945

0.194428

0.133413

๑. 166096

0.188655

0.194687

0.222818

0.270669

0.366928

0. 349361

0.383588

0.441638

0.511298

0.505593

0.559419

3.569440

$0.95766 \mathrm{t}$

1.295625

1. 469436

1. 70626

1.990622

2.392019

2. 862578
0.
a. +0150
0.050100
0. TREISO
ง. บับอิอง

0.000000
0.009002
0.000054

0.

ด. 057867

0.057893 
Table A12. Coordinated fallure model, ux - 1.7/0.90 (F1g.8).

Input variables

$$
\begin{aligned}
& \rho_{0}=1.7 \mathrm{Mg} / \mathrm{m}^{3} \\
& \mathrm{P}_{T}=100 \mathrm{kPa}
\end{aligned}
$$

$$
\begin{gathered}
S_{w}=0.90 \\
P_{H}=14.7 \mathrm{MPa} \\
\underline{\text { Output }}
\end{gathered}
$$

$$
\begin{aligned}
& z=0.2901 \\
& e_{w}=1.0913
\end{aligned}
$$

$\mathrm{K}=5.0 \mathrm{GPa}$

$\phi_{\mathrm{a}}=0.0548$

$\mathrm{EV}=31.773 \mathrm{~kJ}$

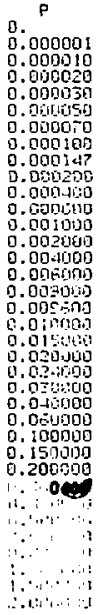

$0.5 \% 2535$

0.583224

0.57275

0.568163

0.565 .145

0.561953

0.559581

$0.55 i 5366$

$0.55=972$

0. 50699

จ. -1.1 .2283$

0. 515835

$0.5 \div 4151$

0. 5201726

0. 5101060

0.45339

0.46513

0. +25042

0.181824

0. 1:102E

0.456534

$0.4 .15-148$

$0.4 \geq 0024$

B. 402941

a. 374113

0. 352247

11, l1, 1.:?

11. 1..1\%

1.: : $: \because ;$

11. , i 11 $\therefore$ - I11 B קर1

11. $. . \therefore 1-1 \div, 6,31,3$

$11 . .11 \% \cdot 1 !-18,2601,5$

$11.1 \cdot 113:-2.4 .11113056$
DP/DV NU

$-0.085002$

$-0.000582$

$-0.002173$

$-0.005727$

$-0.008438$

$-0.011473$

-0.074946

$-0.077952$

$-0.082755$

-0.089927
-0.106573

$-0.14260$

$-0.192940$

$-0.302120$

$-0.31-1674$

$-0.378255$

$-0.500113$

$-0.605718$

$-0.876275$

$-1.147882$

$-1.594661$

$-1.734453$

- - E1070?

$-5.052 .153$

$-7.103701$

0. 000020

0.027012

0.035329

0.040354

0.046769

B. 051207

0.056142

0.061858

B. 063207

0.068160

0.072869

0.081644

0. 100634

0. 130295

0.153266

0. 180436

0.185209

0.188253

0.220852

0.246721

0. 264410

0.297636

$0.32054 \mathrm{~B}$

6. 374303

B. 459856

0.572346

0.669953

a. 857575

0.931156

1. 079758

1. $1639 n 2$

1. 323936

$1 .+172014$

1.794316

2.08B445
0.

0. 950 อยด

0.000333

0.001202

$0.0020 \mathrm{J0}$

0.003094

0.004506

อ. 006079

ด. 008235

0.339050

0.040375

0.042 478

B. 045584

0.052659

0.067427

0.087067

๑. 110216

0.127021

0. 151434

D. 153378

0. 193280

B. 226028

0.258424

0.303833

0. 372059

0.467549

0.444483

0.512260

0.532985

0.809183

1.014183

I. $12064 a$

1. 250444

1. 320061

1. 555199

1. 699939

DIII.MITHG PÄTH

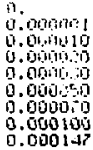

1. $1 \cdots \cdot 1+3$

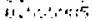

11. $\because 195$

6. $\because 417$

1.1.

i. $2,5=$

6,7010

0.55597?

0.057940
9.059998
0.058248
9.053516
0.053782
9.059314
0.059842
0.068599
0.061858

$d$.

0.037216

0.037269

0.037370

0.037476

0.037636

0.037648

0.838113

ด. 038521 
Table Al3. Coordinated fallure model, $J \mathrm{X}-2.1 / 0.90$ (FIg. 8).

Input virfables

$$
\begin{aligned}
& p_{0}=2.1 \mathrm{Hg} / \mathrm{m}^{3} \\
& P_{T}=100 \mathrm{kPa}
\end{aligned}
$$

$$
\begin{aligned}
& z=0.1380 \\
& e_{w}=0.4275
\end{aligned}
$$

$$
\begin{aligned}
& S_{w}=0.90 \\
& P_{M}=14.7 \mathrm{kPa}
\end{aligned}
$$

\section{Output}

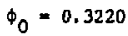

$E F=8.551 \mathrm{~kJ}$
$K=5.0 \mathrm{GPa}$

$$
\phi_{\mathrm{a}}=0.0322
$$

$\mathrm{EV}=39.04 \mathrm{~kJ}$

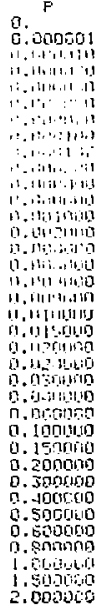

LEHIIIIG PATH

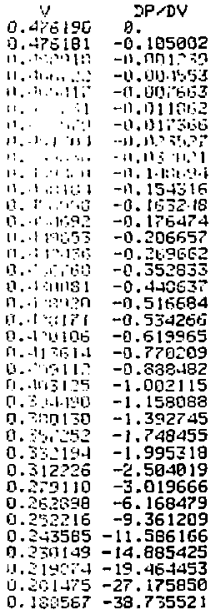

0.

6. 800020

0. n1550s

0.02928

0.023149

0.0250159

1. ㅁ. ㅁำ5

ก,113??

n.1150

0.115359

0.059301

0.0.+2087

0.047282

0. 658547

0.076292

0. 090260

0. 107212

ด. i1 2029

0. 112151

0. 133591

0.151291

0. 163961

0.181248

0. 207105

$0.252,05$

0.332925

0. 453472

0.525148

B. 796106

0.911312

0.

0.954927

1.069055

1.165746

i. 363522 b.

6. 950980

อ. กคอ581

ด. 002093

0.003496

0.005376

0.1117823

0.1111543

0. 51.1254

$0.11,5976$

0.965224

0. 971777

b. $a>7001$

0.088768

0.112716

0.145182

b. 176976

0.20015 ?

0.206049

0.234187

0.291049

0.315722

0.347071

$0.386,55$

อ. 438590

0.498633

0.497277

0.545402

0.552614

0.950516

1. 303500

1. 494794

1.752425

2.068443

2.528115
3.090405

\section{UNLQADING PATH}

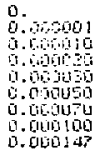

9. .

10. - 6094

1. 0.0 .35

î. 4101

U. $\sin 15.41$

1. . 505

ด. -

0.2515150

บ. 459836

0.033275

0.033291

0. 933135

0.033592

0.033756

0.034065

0.034378

0.034844

0.035566 o.

0. 062858

-.062948

0.063120

0.063301

0.063572

อ. 053933

0.064364 
Table A14. Coordinated fa1lire model, SX - 1.7/1.0 (F1g. 8).

Input variabies

$$
\begin{aligned}
& \rho_{0}=1.7 \mathrm{Mg} / \mathrm{m}^{3} \\
& \rho_{T}=10 \mathrm{kPa}
\end{aligned}
$$

$S_{n}=1.0$

$\mathrm{K}=5.0 \mathrm{GPa}$

$P_{M}=68.9 \mathrm{MPa}$

Output

$$
\begin{aligned}
& z=0.3417 \\
& e_{w}=1.386
\end{aligned}
$$

$$
\begin{aligned}
& \phi_{O}=0.5808 \\
& E F=6.612 \mathrm{~kJ}
\end{aligned}
$$

$\phi_{a} \bullet 0$.

$E V=33.30 \mathrm{~kJ}$

\section{L_IHLING PATH}

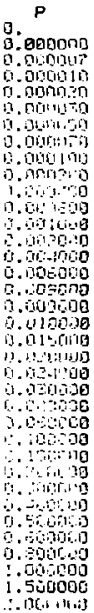

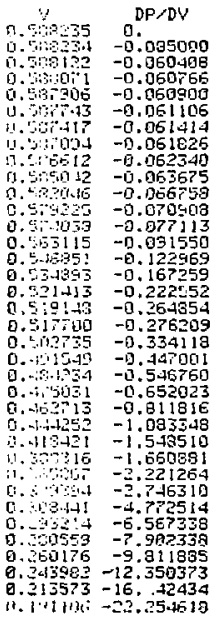

0.

G.000002

0.903193

อ. 000286

0. 900569

0.001393

0.001945

0.002767

0.005459

0.010634

0.015555

0.024332

B.04a509

0.075678

D. 099724

n. $128: 55$

1. 133078

0. 136248

0.170070

อ. 195695

0.2147>6

G. 238368

घ.271274

0.324102

0.405846

g. 514835

5. 798050

0.185810

0.907125

1. 0 อ6 154

1. 096551

1.250913

1.410976

i. 754258

2. 978061
0.009838
$\mathrm{DP} / \mathrm{DHW}$

3.

๑. 950090

0.035728

0.035794

g. 035894

D. 036046

0. 036247

B. 136498

0.038645

0.040640

6.043528

0.050309

0.064374

ด. 983171

อ. 1 อง 19

0. 121879

0.126199

- 147931

0. $: 97786$

b. 221242

0.254970

0. 305348

0.37858 :

a. 489335

0.458761

$0.5 \times 6397$

0. 562556

0.824397

1.009705

i. 105132

1.217569

1.332767

1. 456531

1.544150
0.037150

I:ALUNIHE PATH

19. $11.9 \cdots \div$

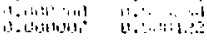

ก. กองกng

1..

a.

0. 000193

0.035643 
Table A15. Coordinated fallure mode1, Sx - 2.1/1.0 (Fig. 7).

Input varlableg

$$
\begin{aligned}
& p_{0}=2.1{\mathrm{Mg} / \mathrm{m}^{3}}^{3} \\
& P_{T}=10 \mathrm{kPa}
\end{aligned}
$$

$$
\begin{aligned}
& z=0.2625 \\
& e_{W}=0.5282
\end{aligned}
$$

$S_{w}=1.0$

$P_{M}=\$ 8.9 \mathrm{MPa}$

Output

$\phi_{0}=0.3413$

$E F=8.926 \mathrm{~kJ}$
$K=5.0 \mathrm{GPa}$

$\phi_{\mathrm{a}}=0$.

$E V=40.32 \mathrm{~kJ}$

\section{LËDING PATH}

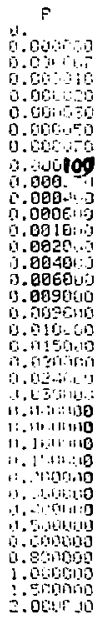

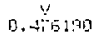

0.4 4199 $D P / D V$

1. 210190

a.

$(1,-4513.9$

$-105300$

a. 150

c. -4.50

[1. $+1: 55+45$

$-0.121657$

$-0.121851$

$-0.122199$

Q. -17502

$-0.122503$

0.4.56?

$-0.123092$

6. - 4.50

-0. 125879

$\therefore 1,913$

1. -7035

$1,-i 15$

-1) 124862

$-0.127 .408$

$-0.133273$

$-0.141124$

$\because, 3,59$

- อ. 152776

$9+40+83$

0.45 .205

0. $-4 \div 31$

- 3.179499

$-j .255798$

11. 거10i6

0.479732

$-0.311258$

$-0.399749$ $-0.463615$

$0.49+49-0.430250$

ด.17.96 - 0.708535

1. . . 156

$-13.825509$

$-0.9412 \% 2$

0.4.

$-1.101526$

$-1.346-155$

1.. : : : $: 4.17$

$11, \ldots 11.15$

$-1.72169 \mathrm{i}$

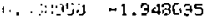

11. 1065 -2.46E235

11. $2163-2.933910$

9. 1.3 -5.958647

a. $5.51-9.505153$

0. $25036-10.970493$

B. 454 - 14.013109

0. $2776-18,202208$

$0.2 .2031-25.195779$

$0.1006 \frac{1}{3}-35.564759$

0.

ด. 500002

0.000119

0.000173

0.000345

D. 906516

0.009858

ด. 01198

0.001704

0. 003361

0,006543

0.009567

a. 815203

0.027.86

ด. 046558

0.061549

0.079611

0.082738

0.084843

0.107282

B. 125755

0.13878?

0. 156416

$0.1824 B 5$

0. $227>72$

0.306005

0.494898

๑. $49427 ?$

0.669888

0,774305

0.851791

0.919844

1.

1.137531

1.346559

1. 521227

DP $/ D M$

b.

0.050908

0.057925

$0.05800 \mathrm{~B}$

0.058117

a. 058284

0.058535

0. 058869

อ. 059286

0. 060365

0.062840

0.066132

0. 370982

9.081945

0.104428

0. 133413

อ. 166096

อ. 188855

0.194687

ด. 222919

B. 270669

0. 306928

Q.340351

D. 38358 a

อ. 441638

0.511298

0.565593

0.559419

D. 569449

0.557661

1.290625

1. 469439

1.706261

1. $990 \mathrm{~b} 22$

2.392019

2. 262578

IIILOHIING PATH

$\begin{array}{ll}\text { O. } & 0.450150 \\ 0.00000 \% & 0.476134\end{array}$

0. อ10ต0อง

0.000502

0.000119 g. 0.057867 0.057925 
Table A16. Coordinated fallure model, $\mathrm{CH}-1.7 / 0.90$ (FIg. 9).

Input variables

$$
\begin{aligned}
& \rho_{0}=1.7 \mathrm{Mg} / \mathrm{m}^{3} \\
& P_{T}=b \mathrm{Ma}
\end{aligned}
$$

$$
\begin{aligned}
z & =0.2901 \\
e_{v} & =1.091
\end{aligned}
$$

$$
\begin{aligned}
& S_{W}=0.90 \\
& P_{M}=21.5 \mathrm{MPa}
\end{aligned}
$$

Output

$$
\begin{aligned}
& \phi_{0}=0.5480 \\
& E F=5.939 \mathrm{~kJ}
\end{aligned}
$$

$K=5.0 \mathrm{GPa}$

$\phi_{\mathrm{a}}=0.0548$

EV $=31.77 \mathrm{~kJ}$

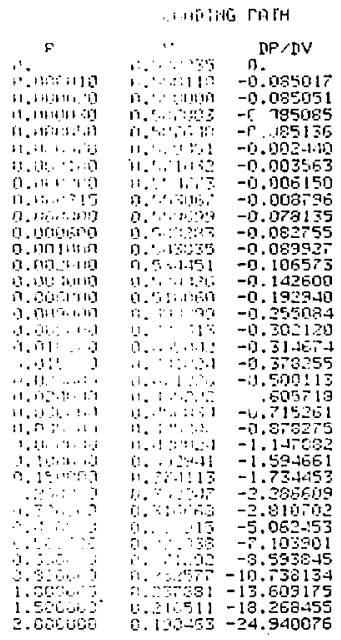

AT ATING PHTH

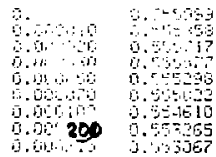

0.

$0 . \min 200$

0. 000.400

9.

9. 0 ก)

0.015159

a. 050126

0.060318

0.06359 ?

0.069160

0. 072869

๑.

0.100634

0. 130295

0. 153256

a. 180436

0. 1552199

a. $10 \mathrm{e} 255$

0.220852

9.2य1E 2 :

จ. 20.413

[1. 297636

$0.32054 a$

0. $37+503$

อ. 459956

3. 573346

0.679953

0.857575

0.981156

1.07959

1.162992

1.328936

1. 472814

1. 794316

2.033445

D.

[ip/Iint

D.050009

- . 950000

6. 950009

$3.05 \mathrm{Qng}$

0.001413

0.002004

0.003312

0.094588

0.040456

0.042479

0.0 .15584

0.052659

0.067427

0.087067

0.119216

0. $12 \mathrm{roz1}$

0.131434

0.153378

c. 193250

B. 235020

0. 259424

0.303833

0.372059

0. $46.75-49$

0.444 .393

$0.51 \div 250$

0. 532985

0.899183

1. 014183

i. 120644

1. 250444

1. 390061

i. 555199
0.057960
0.053243
0.055516
0.059792
0.059314
0.059942
0.060529
0.063297
0.063597

0.

0.057264

0. 25370

6.037476

0.037636

0.037848

0.038113

0. 938799

0.039410 
Table Al7, Coordinated fallure model, CM - 2.1/0.90 (FIg, 9).

Input varlableg

$$
\begin{aligned}
& P_{O}=2.1 \mathrm{Mg} / \mathrm{m}^{3} \\
& P_{T}=5 \mathrm{MPa}
\end{aligned}
$$

$$
\begin{aligned}
z & =0.1380 \\
e_{v} & =0.4275
\end{aligned}
$$

$$
\begin{aligned}
& S_{w}=0.90 \\
& P_{M}=21.5 \mathrm{MPa}
\end{aligned}
$$

\section{Output}

$$
\begin{aligned}
& \phi_{0}=0.3220 \\
& E F=8.552 \mathrm{~kJ}
\end{aligned}
$$

$\mathrm{K} \approx 5.0 \mathrm{GPa}$

$$
\begin{aligned}
& \phi_{a}=0.0322 \\
& E V=39.04 \mathrm{~kJ}
\end{aligned}
$$

I. DHAINE FATH
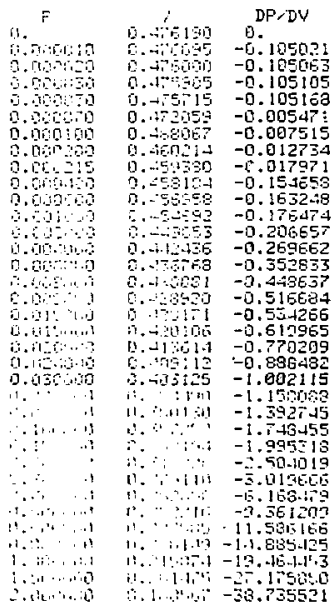

0.

0.000200

0.050400

0.000690

0.001000

0.008751

0.017355

0.034714

0. 036594

0.039301

0. $0 \leq 208 ?$

อ. 047282

0.058547

0.076292

0.099260

0.107212

0.110209

0.112151

ด. 133501

0.15129

3. 163961

0.181248

0.207105

0.252705

$0.3 \mathrm{j} 2925$

0.153412

0. 525 I 43

0. $\overline{1} 06106$

0.811312

0.808025

0.354927

1. 01.9055

1. 165046

1. 363522

1.525313
DP/DMJ

0.0500ต0

0.050500

0.050000

B. 050000

0.002586

0.003487

0.005760

0.007979

0. 068360

0. $0 \vec{r} 1.77$

0.077901

0.083768

0. $1: 2710$

อ. 143182

0. 176976

0.260157

0.206049

อ. 234187

0. 281049

0.315722

0.347 a? 1

0. 386755

0.438590

0. 498633

0.497277

0. 5.9492

0. $55^{2} 2614$

อ. 950516

1.303509

1.494794

1.752425

2. 058443

2.528115

3. 990495

\section{IULLัUISIHG PATH}
ii.

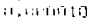
11.1 - 11..14.
$11.1 .: 4 \ldots+10$

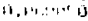
U. Enthe
b. 1110!1,
(1. kiraton
a. vous is

1. .

11...11 at:

1). I I.

0..1.12..2.1

5 त)

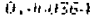

$0,11,1 ! 5$

6., 7.8.6

0.95000

.033275

0.03345

1. 1535592

6. $053 \div 5$

0.034065

0.054378

$0.03+844$

0. $0353 \mathrm{E}, \mathrm{S}$

0.036534
0. 0.062939 0. 063120 0.6163501 0.065572

0.053933

0.064384

0.065559 
Table A18. Coordinated fallure mode1, CX - 1.7/0.90 (F1g. 9).

$$
\begin{aligned}
& \rho_{0}=1.7 \mathrm{Mg} / \mathrm{m}^{3} \\
& P_{T}=j \mathrm{MPa}
\end{aligned}
$$

$$
\begin{aligned}
& z=0.2901 \\
& e_{w}=1.091
\end{aligned}
$$

Input vartableg

$$
\begin{array}{ll}
S_{W}=0.90 & K=5.0 \mathrm{GPa} \\
P_{M}=25.1 \mathrm{MPa} &
\end{array}
$$

Output

$$
\begin{aligned}
& \phi_{0}=0.5480 \\
& E F=5.939 \mathrm{~kJ}
\end{aligned}
$$

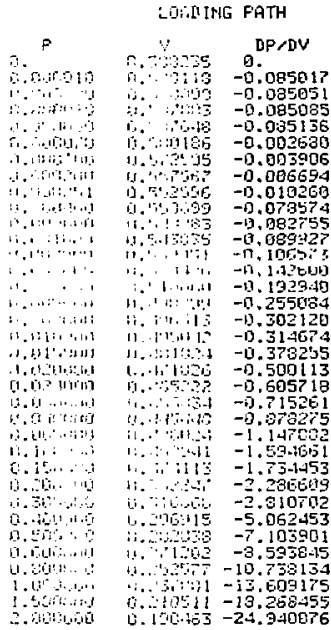

14 LDAING FATH

i.

i. 0000110

.0000

$1.00150=$

$0000=3$

. $0000 \%$

3.0001\%

0. 060\%in

i. - . 1000:
0. 5595

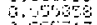

1. $\because 1=$

1. 5040

$\therefore \div 5=23$

1. $\therefore=10$

$6.5 c^{2} 35$
MU

0. .090200

0.000408

0.000600

๑. 001000

0. 913873

0.027476

0.055804

0.064495

8. 668158

0.072869

0.031644

จ. 100634

0. 130235

8. 153266

0. 190436

0.135209

0.108253

0.220852

0.246721

0.264418

ด. 237636

ด. 32054

0.374303

0.459856

0.572346

0.669953

0. 857575

0.981156

1. 079758

1. 168992

$1.3 \geq 3936$

1.472814

1.794316

2. 986445
G.

D.05e日ea

0. 050000

0.050000

0.050000

อ. 001554

0.002205

0.003633

อ. 005374

อ.

0.0424ra

0.045584

0. 067427

0.097067

8.110216

D. 127021

อ. 131434

อ. 153378

ด. 193280

0.226029

0. 258424

a. 305833

a. 372059

0.467549

0.444483

0.512260

0. 552985

0.009183

1.014183

1. 120644

1. 250444

1.390061

1.555199

1.699939
0.057580

0.05823

0.056516

‥ 050782

0.059514

0.059342

0.066629

0.06320 ?

0.664 495
ด.

a. 937264

0.037370

a. 037476

0.037635

0.037848

อ. 933113

0.03979 
Table A19. Coordinaced fallure oodel, CX $-2.1 / 0.90$ (FIg,9).

Input partableg

$$
\begin{aligned}
& \rho_{0}=2.1 \mathrm{~kg} / \mathrm{m}^{3} \\
& P_{T}=5 \mathrm{MPa}
\end{aligned}
$$

$$
z=0.1380
$$$$
e=0.4275
$$

$$
\begin{aligned}
& S_{w}=0.90 \\
& P_{M}=25.1 \mathrm{MPa}
\end{aligned}
$$

Output

$$
\begin{aligned}
& \Phi_{0}=0.3220 \\
& E F=8.552 \mathrm{~kJ}
\end{aligned}
$$

\begin{tabular}{|c|c|}
\hline 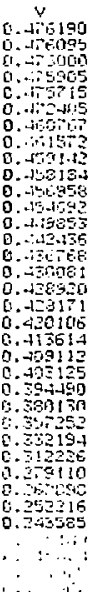 & $\begin{array}{l}\text { DP/DV } \\
0.0 \\
-0.1050 \\
-0.1050 \\
-0.10510 \\
-0.1051 \\
-0.9064 \\
-0.0082 \\
-0.0135 \\
-0.020 \\
-0.155 \\
-0.1632 \\
-0.170 .4 \\
-0.2066\end{array}$ \\
\hline
\end{tabular}

$K=5,0$ GPa

$$
\begin{aligned}
& \phi_{a}=0.0322 \\
& \mathrm{EV}=39.04 \mathrm{~kJ}
\end{aligned}
$$

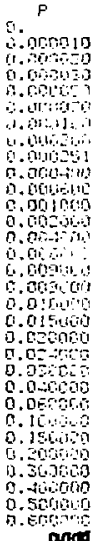

ood

\section{LiTnDING PATH}

MV

B.000280

0.000400

0.600609

0.001000

0.008ala

0.015835

0.031671

0.05131

v.039391

0.042087

0.047232

0.058547

0.076292

0.050260

0.107212

0.110289

0.112151

0. 133501

0. 151291

0.163961

0.101248

ด. 207105

0.252705

0.332925

0.433472

0.525148

6.706105

0.811312

0.888026

0.954927

1.069055

i. 165746

1.5655232

if IIIING FHTH

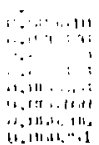

1). $115 \%+6$

$11.11,515$

$11.11 \% 3 \mathrm{~s} 4$

- 1.135100

$17.05+10+5$

1. 03473

0.05 JEㅔㄴㅔ

0.056569

0.037131
B.

0. อ5อaอต

0.05000

0.051000

0.050000

0.00285

0. 043836

0.006315

0.009340

0. 068686

0.071777

0.077001

0.088768

ด. 112710

อ. 145182

0.176976

0.200157

6.206049

0.23418 ?

D. 281049

g. 315722

0.34797

Q. 386755

0.438590

0.498633

0.497277

0.545402

0.552614

0.950516

1.303500

1.494794

1. .52425

z. 068443

2. 528115

3.090465

0.

0. ค1.2959

0.0631 ,

0. 05ร5)

0.083572

0.065933

0.064384

0.065550

0.066908 
Table A20. Coordinated fallure mode1, 只 - 1.7/0.90 (F15, IU; .

Input vartableg

$$
\begin{aligned}
& \rho_{0}=1.7 \mathrm{Mg} / \mathrm{m}^{3} \\
& P_{T}=8 \mathrm{MPa}
\end{aligned}
$$

$z=0.2901$

$e_{w}=1.0913$
$S_{w}=0.90$

$P_{M}=34.5 \mathrm{MPa}$

Output

$\phi_{0}-0.5480$

$E F=5.940 \mathrm{~kJ}$
$K=5.0 \mathrm{GPa}$

$\phi_{\mathrm{B}}=0.0548$

$E V=31.77 \mathrm{~kJ}$
| II, I!IHG PATH

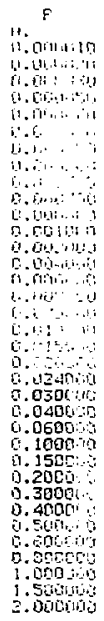

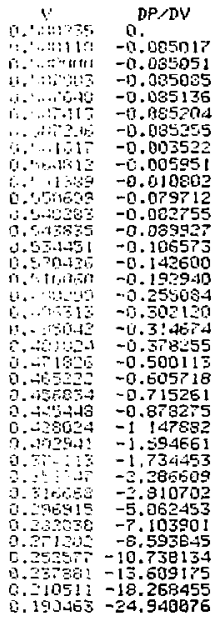

0 .

9. 000200

0.009400

0.00060日

0.001000

0.601400

0.001600

$0: 011379$

0.041470

0.0668?4

0.068160

0.072869

g.

0. . 100634

0. 130295

0.153256

0.180486

0. 195209

0. jeg253

0.220852

0.246721

0.264419

0. 287636

0.320548

0. 374303

0.459856

0. 572346

0.669953

0.857575

อ. 981156

i. 079758

1. 168992

1.328936

1. 472814

1.794316

2.088445
DP $/ D H$

b. 650090

0.050000

0.050000

- 050090

0.050000

ใ.050000

0.002045

0.003323

0.005719

0.041148

0.042478

0.045584

0. 052659

0.057427

0.087067

0. 110216

0.127021

0.151434

0. $15337 \mathrm{~B}$

ด. 193280

9.226028

0.258424

6. 303833

0.372959

0.467549

0.444483

b.512260

0.532985

0.609183

1. 014183

1. 120544

i. 256444

1.390051

1.555199

1. 659939

,HIIIIIIH, PATH

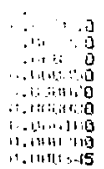
B. . . . . .
Q. $: \because \ldots$ :
0. , $1:$
D. $\therefore \therefore$
D. $\because \cdots$
0.
$0 . \therefore$ in:
6. $\because$.. 11.11
ด.
0. $\therefore 1: 2$

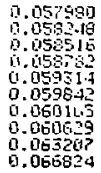

g.

a., 037264

0.037570

0.037475

0.0 27636

0. 0.37648

$0.03000 ?$

0.038106

0.038795

0.040051 
Table A21. Coordinated fnilure model, RH-2.1/0.90 (Fig 10).

Input var1ables

$$
\begin{aligned}
& \rho_{0}=2.1 \mathrm{Mg} / \mathrm{m}^{3} \\
& P_{T}=8 \mathrm{MPa}
\end{aligned}
$$

$z=0.1380$

$e_{w}=0.4275$

$$
\begin{gathered}
s_{v}=0.90 \\
P_{M}=34.5 \mathrm{MPa} \\
\underline{\text { output }} \\
\phi_{0}=0.3220 \\
E F=8.552 \mathrm{~kJ}
\end{gathered}
$$

\begin{tabular}{|c|c|}
\hline$\vartheta$ & DP/DV \\
\hline $.451 \leq 0$ & \\
\hline - - TEUE & 10 \\
\hline : lob & - \\
\hline 0. & \\
\hline (1.-1, & \\
\hline 0.-1,55 & \\
\hline b. $\left.1_{1}<\ldots !+1\right]$ & - \\
\hline Q. $\mathrm{I}_{1}$ it. & - \\
\hline D. & \\
\hline 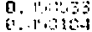 & \\
\hline 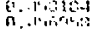 & 16.37 \\
\hline 1...", & -10 \\
\hline $6,-1+6,5$ & \\
\hline $1 . \therefore 15$ & \\
\hline t..1 & \\
\hline 0,1001 & 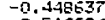 \\
\hline $10+20$ & \\
\hline $0+1 \times 9-1$ & \\
\hline 9.60100 & \\
\hline 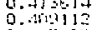 & -0 \\
\hline le.,1ו1 & \\
\hline $6,-: 1.1,111$ & \\
\hline i & \\
\hline 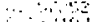 & \\
\hline$\because \cdots \quad \because 1 c_{1}$ & \\
\hline $\begin{array}{l}11 \\
0\end{array}$ & \\
\hline $\begin{array}{l}0 \\
0.2+10\end{array}$ & \\
\hline (i. & \\
\hline 2855 & \\
\hline $0,2: 3-1$ & \\
\hline 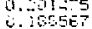 & $=0$ \\
\hline
\end{tabular}

$\mathrm{R}=5.0 \mathrm{GPa}$

$$
\begin{aligned}
& \phi_{\mathrm{a}}=0.0322 \\
& \mathrm{EV}=39.04 \mathrm{~kJ}
\end{aligned}
$$

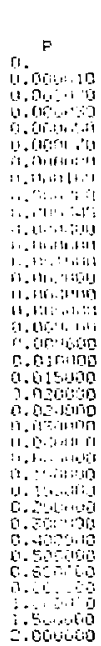

6.

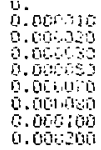

\section{LË:UJWG PATH}

9.

9.000200

ค. 100490

0. 000600

0.001940

0.001400

0.001600

0.006606

0. 023919

0.038510

0.039301

0.042087

0.047282

0.058547

0.076292

o. 190269

ฮ. 107212

b. 110209

0.112151

0. $[33591$

0.151291

o. 163951

0. 181248

0. 207105

0.252795

0.332925

$0.4354>2$

0.525148

0. 7010106

0.611312

0. 8 38028

0.954927

1.069055

1. 105746

1. 363522

1. 525313

c.

0.059aba

0.050000

0.050000

0.050000

0.050000

B. 05090

0.003995

0.005776

0.009938

0.069531

B.071777

0.077901

6.988768

Q. 112710

D. 143182

6.176976

0.200157

0.206049

0.234187

0.281049

0.315722

0.3가

0.386755

0.758590

0.408533

B. $49727 ?$

0.545402

0.552614

0.950516

1. 303500

1. 594794

1. 52425

2.066443

2. 528115

3.090405

\section{I:LDیI ING PATH}

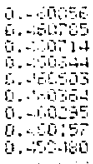

0.033275
0.033434
0.03559
0.033750
0.034065
0.034379
0.034533
0.034844
0.036369
0.039510

0.

0.062939

0.063120

0.063301

0.063572

0.063933

0. 064204

E. 064474

B. 065550

0.067741 
Table A22. Coordinated fa1lure mode1, RX - 1.7/0.90 (F1B. 10).

Input variablea

$$
\begin{aligned}
& \rho_{0}=1.7 \mathrm{Mg} / \mathrm{m}^{3} \\
& P_{T}=8 \mathrm{MPa}
\end{aligned}
$$

$Z=0.2901$

$\mathbf{t}=1.091$

$$
\begin{aligned}
& S_{W}=0.90 \\
& P_{M}=60 \mathrm{MPa}
\end{aligned}
$$

Output

$$
\begin{aligned}
& \Phi_{0}=0.5480 \\
& E F=5.941 \mathrm{~kJ}
\end{aligned}
$$

$\mathrm{K}=5.0 \mathrm{GPa}$

$$
\begin{aligned}
& \phi_{a}=0.0548 \\
& E V=31.78 \mathrm{~kJ}
\end{aligned}
$$

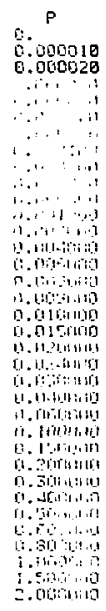

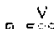

0.59235

0. 585110

0. 565000

11. $\because \because \div$

$\because \therefore$ i.

$1 . \quad 31$

i. 1 , 1 ,

1i. 9 . $11.140^{\circ}$

1. . n...

11.' ?.:.

19. 1.:

(1. $\therefore t^{2}+1$

11. $\therefore \cdot 1.10$

1. ringes

$0.1,: 2 \%$

ด. idisis

11. 195013

$1 f_{1}, 1=1,24$

11..1\% 1:3

11. 11,12

A. 1 in:

1.. + . -1.19

19. 4 ?

0. 12:3)

n. 3.311

(1. $\because 2.2 .17$

บ. 71606

11. 9115

16.

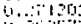

li. - 3

t. josti -13.268455

c.).

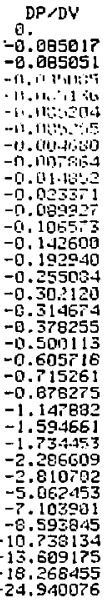

g.

0.000200

0.000400

ล. กกกรกล

D. valivo

0.001400

0. rivt.0n

0.0439 .12

0.031438

0.056531

0.0.2859

0.081544

a. 100634

D. 130295

0. 153266

0. 190436

D. IE5299

Q. 188253

0.220852

$0 . \bar{c} 46721$

0.264418

0.267536

อ. 320549

0. 374303

0.459856

0. 572346

0.669953

0.857575

0.931156

i. 079758

1. 168992

1.320936

1. 472814

1. 794316

2.088445

IILGAIIING PATH

C.

0, $0 \sin 0$

Q b. nollin

อ. Tian:1

1. 0065

อ. [1,

0.0 .50090

0.000193

[1.000 2011

D. $0004 \mathrm{H}$

D. 0.20000
0. 5

0.15505

$0.55=17$

$0 . \therefore$

0.650

$0.561 z$

$0.5,5401$

0.5 inio

$0.5 \% 65$

C. 551399

ข. 5.13253
0.057980

0. 058248

0.058515

0. 05873 ?

0.059314

0.05984 ?

0.060105

$0.060=29$

0.063297

0. 068168
DPRM

$\theta$.

0.050000

0.050000

อ.กรดกลด

0.050600

0.050000

0.050000

0.0102724

0.004445

0.0178018

घ.012138

9.945584

0.052659

$0.05742 ?$

0. 08706 ?

Q. 110216

0.127021

Q. 131434

0. $15337 \mathrm{P}$

0.193280

0. 226028

0.259424

0.303933

0.372059

0.467549

0. 444483

0.512260

0. 532985

0. 809163

1. 014183

1. 120644

1. 250444

1.390061

1.555199

1.699939

4.

9.03726

0. 057370

0.037are

0.037636

0. 037848

0.038007

0.033166

B. 038799

0.040376

0.042478 
Table A23. Coordinated fa1lure model, RX - 2.1/0.90 (F18. 10).

Input variables

$$
\begin{aligned}
& \rho_{0}=2.1 \mathrm{Mg} / \mathrm{m}^{3} \\
& P_{T}=8 \mathrm{MPa}
\end{aligned}
$$

$$
\begin{array}{r}
z=0.1380 \\
e_{v}=0.4275
\end{array}
$$

$$
\begin{aligned}
& S_{w}=0.90 \\
& P_{M}=60 \mathrm{MPa}
\end{aligned}
$$

\begin{tabular}{|c|c|c|c|c|}
\hline & L[نं[1] & IG PATH & & \\
\hline$P$ & Y & $D P / D V$ & $\mathrm{rd}$ & $\mathrm{DP} / \mathrm{DH}$ \\
\hline م. & a.4. & ย. & O. & 8. \\
\hline $\begin{array}{l}0.509010 \\
0.0000>0\end{array}$ & B. 476995 & -0.185621 & 6.9019200 & a \\
\hline 60 & 0.4759015 & & & \\
\hline 0.00 & 0.475 .15 & & & \\
\hline 0.000070 & 0.45525 & 95252 & 0. ae & \\
\hline Q. กดนกต & $0.4754 \geq 0$ & 25315 & 0.00 & \\
\hline 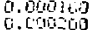 & Q. 403 & 11717 & 0.005209 & 42 \\
\hline 0. & $\begin{array}{l}0.451692 \\
0.451172\end{array}$ & $\begin{array}{l}-0.015580 \\
-0,030677\end{array}$ & 0.018156 & \\
\hline 600 & D. 40.75 & & & \\
\hline 190 & 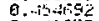 & & & \\
\hline 2000 & 0.444055 & $-\overline{8}$ & & \\
\hline 0.004000 & $0.44 \geq 435$ & & & \\
\hline 0.096000 & 0.36768 & & 0.0 & \\
\hline 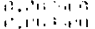 & $1 ;. \cdot \cdots \cdots$ & & 12 & \\
\hline $1.11,: 11$ & $11 . .1 .4 .71$ & -11 & & \\
\hline 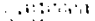 & $\because \ldots \ldots 1: 1$ & & & \\
\hline$\therefore \theta^{\circ} \quad \ldots$ & $\therefore a_{1}, t_{1}$. & $\times 5$ & & \\
\hline$\therefore-1 .+1$ & $\therefore, . \leq 1 \leq i, i .1$ & & & \\
\hline $11.1 \because \because \cdots$ & $15, \therefore 1117$ & & & \\
\hline $1.1151 .4 ; .17$ & 4". & -1 & & \\
\hline & В. $\because, 1)$ & & & \\
\hline 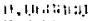 & 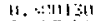 & & & \\
\hline 11119 & D. & & & \\
\hline 1. 14 & 19. $\therefore 114$ & & & \\
\hline ח. & ก. $\div 19 ? 5$ & & & \\
\hline 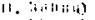 & $(1 . .4 \div 1110$ & -3 & $61+36$ & \\
\hline & 1, . & & & \\
\hline 1) & $0,86, \cdots 16$ & 3612 & & \\
\hline & $0.21,180$ & -11.556165 & & \\
\hline 311, ifige & 9. 301149 & -14.685425 & 655 & \\
\hline 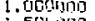 & $9.313 \pi 44$ & $-19,464453$ & & \\
\hline $1.5 f$ & $0.201+15$ & -27.175 & & \\
\hline & & & & \\
\hline
\end{tabular}

Output

$$
\begin{aligned}
& \phi_{0}=0.3220 \\
& E F=8.553 \mathrm{~kJ}
\end{aligned}
$$

$\mathrm{K}=5.0 \mathrm{GPa}$

$$
\begin{aligned}
& \Phi_{\mathrm{a}}=0.0322 \\
& E V=39.04 \mathrm{~kJ}
\end{aligned}
$$

LNLOADJNG PATH

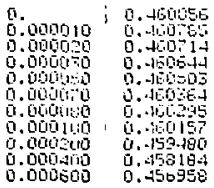

0. 0133275

0.033434

0.033592

0.033750

0.0340155

0.034578

0.034533

0.034544

0.836369

0.039381

0.042087
B.

0.062939

0.063120

0.063301

อ. 063572

อ. 063933

0.064294

0.064474

0.06555E

0.068224 
Table A24. Coordinated fa1lure mode1, $\mathrm{CX}-1.7 / 0.90$ (2.5) (F1g. 9).

Input variables

$$
\begin{aligned}
& \rho_{0}=1.7 \mathrm{Mg} / \mathrm{m}^{3} \\
& P_{T}=5 \mathrm{MPa}
\end{aligned}
$$

$$
\begin{aligned}
& z=0.2901 \\
& e_{w}=1.091
\end{aligned}
$$

$$
\begin{aligned}
& S_{w}=0.90 \\
& P_{M}=25.1 \mathrm{kPa}
\end{aligned}
$$

\begin{tabular}{|c|c|c|}
\hline & LIAHI!IH & IE PATH \\
\hline $\mathrm{P}$ & & $\mathrm{DP} / \mathrm{DV}$ \\
\hline a. & م. & - \\
\hline & 0. & \\
\hline & $6,5: 75 \mathrm{~m}$ & -0 \\
\hline & 0.7itul & -0.042035 \\
\hline & 2.saline & $-[1.00209$ \\
\hline & 1. $4=65=$ & \\
\hline & & \\
\hline 1 & $0,40,73$ & \\
\hline & צ: & 857 \\
\hline & $3+15$ & \\
\hline & 106 & -3. \\
\hline 0. Chention & 13. $5714=0$ & \\
\hline & .5101600 & 40 \\
\hline & {$[:-19629$} & \\
\hline 0.0 & $0,-06313$ & 021 \\
\hline & 6. & 514 \\
\hline & $8 .+13$ & \\
\hline 12 & 0.471325 & \\
\hline a & 0.45533 & \\
\hline & $0.2+5=20$ & -8.87 \\
\hline & $5,+200$ & \\
\hline & & \\
\hline & & \\
\hline & & \\
\hline 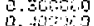 & $\therefore 1068$ & 8.4 \\
\hline 9010 & $5,-8+3$ & \\
\hline & & \\
\hline $1, i$ & 87 & 34 \\
\hline & O19511 & \\
\hline & G. IEGL & -24.949076 \\
\hline
\end{tabular}

Dutput

$$
\begin{aligned}
\phi_{0} & =0.5480 \\
E F & =5.939 \mathrm{~kJ}
\end{aligned}
$$

\author{
$\mathrm{K}=2.5 \mathrm{GPa}$
}

$$
\begin{aligned}
& \phi_{a}=0.0548 \\
& E V=31.77 \mathrm{~kJ}
\end{aligned}
$$

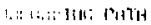

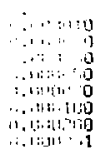

MU

.. 096400

ต. 000800

0.1301250

0.002000

0. 813873

0.027476

0.055004

J.064495

0. 048160

ด.คว 2869

0.031644

อ. 100634

ด. 139295

0.153256

0.180486

0. 185299

0.188253

0.220852

0.346721

ด. 264418

ด. 287636

-. 320548

ด. 374303

ข. 459856

0.572345

0.669953

0.857575

日. 98115

1.00975

1. 168992

1.338936

1. 472814

1. 794316

2.088445 a.

0.025000

0.025000

0.025900

0.025000

0. 001684

0.062215

0.005633

ด. 09537.2

$0.0-10649$

0.0424 ?

0.045584

0.052659

0.06742 ?

$0.08706 ?$

0.110215

Q. 127021

Q. 131434

ด. 153378

0. 193380

0.226028

a. 258424

a. 305833

0.372059

0. 467549

9. 444483

..51226

ด. 332555

o. 509163

1.014163

i. 120544

1. 250444

i. 390051

1. 555199

1. 699939
1.

11.19 .45

11.1134 .11

11. 1519 : 2

1.1.1.150.1.1

0.059 .12

1. butoga

4. 003207

0.1 .64495
D.

10.03.25.4

‥ 10150

0. 83.416

0.93653

0.037845

0.033113

9.038799

0.039599 
Table A25. Coordinated fallure mode1, CK - 1.7/0.90 (7.5)(F1g. 9).

Input variebleg

$$
\begin{aligned}
& \rho_{\mathrm{O}}=1.7 \mathrm{Mg} / \mathrm{m}^{3} \\
& P_{\mathrm{T}}=5 \mathrm{MPa}
\end{aligned}
$$

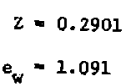

$$
\begin{aligned}
& S_{w}=0.90 \\
& P_{M}=25.1 \mathrm{MPa}
\end{aligned}
$$

\section{Output}

$\phi_{0}=0.5480$

$E F=5.939 \mathrm{~kJ}$

$$
\mathrm{K}=7.5 \mathrm{GPa}
$$

$$
\begin{aligned}
& \phi_{\mathrm{B}}=0.0548 \\
& E V=31.77 \mathrm{~kJ}
\end{aligned}
$$

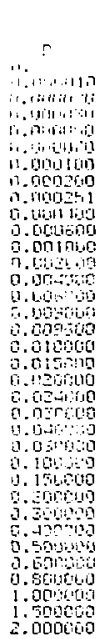

$$
\text { a. }
$$

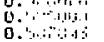

$0.2+1010$

$0 ., 135$

[1. +400

c. 50.400

6.5.725

G. 5,05

Li. 5 is 1

(6)

u. $\because+1500$

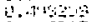

0. -2515

$0.43=2-3$

a. $19 ! 3.0 .4$

$0.410=0$

6.

i.

$1, \therefore 012$

17.

6.

0.23

a. $\mathrm{i}=\mathrm{E}$

11.28 315

a.

- 1050

6...

6. $3001-13.609175$

0.210.511-15.268455

0. 1.0403 - 24.940076

LIIITAEA ING FHTH

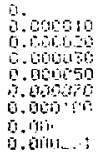

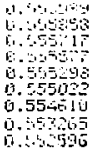

0.057980 0.058245 c. 058516

0.053792

0.059314

0.059842

0.060629

0.053207

0.064495 a.

0.037264

0.07370

0.037476

0.037636

0.038113

0.036799 
LLL Internal Distribution

Roger E, Batze1, L-1

J. M. Thomsen, L-200

J. B. Bryan, L-200

C. M. Sne11, L-200

L. S, Germain, L-203

D. E. Burton, L-200

J. L. Cortez, L-200

M. E. Cunningham, L-200

M. Heusinkve1d, L-205

J. Toman, $\mathrm{L}-222$

B. K. Germa1n, L-209

L. L, Schwartz, L-212

R. W. Terhune, L-200

J. T. Rambo, L-200

A. E. Lewis, $\mathrm{L}-207$

L. W. Woodruff, L-96

R. N. Schock, L-203

TID File, L-3

Vault Reference, L-9

Externa1 Distribution

Asst, to the Secretary of Defense

Atomic Energy

ATTN: D. R, Cotter

Washington, D.C. 20301

Director

Defense Advanced Research

Projects Agency

ATTN: Technlcal Library

Architect Building

1400 Wilson Blvd,

Arlington, VA 22209

(10)

(6)
Director

Defense Civil Preparedness

Agency

ATTN: RE(ADM)

Washington, D.C. 20301

Defense Docum. Center

(2)

ATTN: TC/M. B. Kahn

Cameron Station

Alexandrıa, VA 22314

Director

Lefense Incelligence Agency

ATTN: DT-2, Weapons \& Systems Diviston

Washington, D.C. 20301

Director

Defense Intelligence Agency

ATTN: DI-7D, Phys. Vul. Div., Edward $0^{\prime}$ Farrell

WashIngton, D.C. 20301

Director

Defense Intelligence Agency

ATTN: Technical Library

Washington, D.C. 20301

Director

Defense Nuclear Agency

ATTN: STSI (Archives)

Washington, v.C. 20305

Directur

Defense Nuclear Agerıcy

ATTN: STTL (Technical Library)

Washington, D.C. 20305

Director

Defense Nuclear Agency

(2)

Washington, D.C, 20305 
Director

Defense Nuclear Agency

ATTN: DDST

Washington, D.C. 20305

Dixector

Defense Nuclear Agency

ATTN: SPSS/T. Kennedy

Washington, D.C. 20305

Director of Defense

Research \& Engineering

ATTN: Dep Dir, Tactical warfare

Washington, D.C. 20301

Director of Defense

Research \& Engineering

ATTN: Dep Dir, Strateglc

Systems

Washington, D.C. 20301

Chairman

Department of Defense Explosive

Safety Board

ATTN: T. Zaker

Room 6AI 45

Forrestal Building

Washingtor, D.C.. 20314

Interservice Nuclear Weapons School

ATTN: Technical Library

Kirtland AFB, NM 87115

Director

Joint Strateglc Target

Planning Staff, JCS

ATTK: Science and Technology

Info Library

Offutt AFB, Nebraska 68113

Commander

Field Command

DNA

ATTN: FCTA-D

Lawrence Livermore Laboratory

P. O. Box 808

LIvermore, CA 94550

Director, Weapons Sy 3tems Evaluation Group

ATTN: Technical Director 400 Army-Navy Drive

Arlington, VA 22202

\author{
Commander, D.S. Army \\ Ballistlc Missile Defense \\ Systems Command \\ ATTN: BMDSC-TEN (N. J, Hurst) \\ P. O. Box 1500 \\ Huntsville, Alabama 35807 \\ Commander, U.S. Army \\ Ballistic Missile Defense \\ Systems Command \\ ATTN : BMDSC-HS \\ P. O. BOx 1500 \\ Huntsville, Alabama 35807 \\ Office, Chief of Englneers \\ Department of the Army \\ ATTN: DAEN-MCD-D \\ Washington, D.C. 20314 \\ Office, Chief of Engineers \\ Department of the Army \\ ATTN: DAEN-RDL \\ Washington, U.C. 20314 \\ Engineer Studies Group \\ ATTN: DAEN-FES/G. H. Orrell \\ 6500 Brooks Lane \\ Washington, D.C. 20315 \\ CoImmander \\ Karry Diamond Lab. \\ ATTN: AMXDO-NP \\ 2800 Powder Mill Road \\ Adelpht, MD 20783 \\ Commander \\ Haxry Diamond Laboratories \\ ATTN: ARXDi-TI, Tech. Lihrary \\ 2800 Powder AfII Road \\ Adelph1, MD 20783 \\ Office, Chief of Research, \\ Development, and \\ Acquisition \\ Department of the Army \\ ATTN: DAMA-CSM/LTC E. V. DeBoesser, Jr, \\ Washington, D.C. 20310 \\ Commanding officer \\ Plcatinny Arsenal \\ ATTN: SMUPA-ND-S/E. Zimpo \\ Dover, NJ 07801
}


Commanding officer

Picatininy Arsenal

ATTN: Technical Library

Dover, NJ 07801

Commanding officer

Picatinny Arsenal

ATTN: P. Angellot:

Dover, NJ 07801

Director, U.S. Army

Ballistic Research Lab.

ATTN : J. H. Keefer

Aberdeen Proving Ground, AD 21005

Director, U. S. Army

Ballist1c Research Laboratories, ATTN: AMXBR-X, J. J. Meszaros

Aberdeen Proving Grounds, MD 21005

Director, U. S. Army

Ballistic Research Laboratories

ATTN: W. J. Taylor

Aberdeen Proving Ground, MD 21005

Director, U, S, Army

Balliscic Research Laboratories

ATTN: Technical Library/Edward Baicy

Aberdeen Proving Ground, MD 21005

Commander, U.S. Army

Aberdeen Research \& Development

Center

ATTN: Technical Library

Aberdeen Proving Ground, MD 21005

Commander, U. S. Army

Engineer School

ATTN : ATSEN-SY-L

Fort Belvo1r, Virginia 22060

Division Engineer, U.S, Army

Engineer Division, Huntsville

ATTN: HNDED-CS/Michael $M$. Dembo P. 0. Box 1600

Huntsville, Alabama 35807

Division Engtreer, 0.S. Army

Englieer Division, Ohlo River

ATTN: ORDAS-L/Technical Library

P. O. Box 1159

Cincinnati, Ohio 45201
Director, U.S. Artny Englneer (5)

Waterways Experiment Station

ATTN: Library

P.O. Box 631

Vicksburg, Mississippi 39180

Director, U.S, Azmy Englneer

Waterways Experiment Station

ATTN: L. F. Ingram

P.0. Box 631

Vicksburg, Mississipp1 39180

Director, U.S. Army Engineer

Waterways Expertment Station

ATTN: William J, Flathau

P.0. Box 631

Vicksburg, Mississippi 39180

Director, U.S. Army Engineer Waterways Experiment Station ATTN: John Strange

P.O. Box 631

Vicksburg, Mississipp 139180

Director, U.S. Army Engineer (21)

Waterways Experiment Station

ATTN: MAJ L. C. Webster

P.0. Box 63I.

Vicksburg, Mississippi 39180

Director, U. S. Army Engineer

Waterways Experiment Station

AT'N: J. Zelasko

P.0. Box 631

Vicksburg, Mississipp1 39180

Director, U.S. Army Engineer

Waterways Experiment Station

ATTN: J, Ehrgott

P.O. Box 631

Vicksburg, Mississipp1 39180

Commander, U.S. Army Materials and Mechanics Research Center ATTN: Technical Library

Watertown, Mass. 02172

Conmander, U.S. Army Matertel (2)

Development and Readiness

Command (DARCOM),

ATTN: AMCRD-BN

5001 Eisenhower Ave.,

Alexandria, Yirginia 22333 
Commander, U.S. Atmy Materiel Development and Readiness

Command (DARCOM),

ATTN: Techntcal Ltbrary

5001 Elsenlower Ave.,

Alexandrfa, Virginia 22333

Commander, U,S, Army Maceriel (2)

Development and Readiness

Command (DARCOM),

ATTN: AMCRD-WN

5001 Eisenhower Ave.,

Alexandrta, Vtrginia 22333

Comnander, U.S. Army

Missile Comrand

ATTN: Technical Libraxy

Redstone Arsenal, Alabama 35809

Comnander, U.S, Army

Missile Command

ATTN: W. Jann/AMCPM-PE

Redstone Arsenal, Alabama 35809

Commander, U.S. Army

Misstle Commnnd

ATTN: W. Fowler/AMSMI-YDR

Reústone Arsenal, Alabama 35B09

Commander, U.S. Aray Mobłlity

Equipment Research \& Development

Center

ATTN: Technical Library

Fort Belvoir, Virglnia 22060

Commander, U.S. Army

Nuclear Agency

ATTN: CDINS-E

Fort Bliss, Tx 79916

Commander, U.S. Army

Nuclear Agency

ATTN; Technical LIbrary

Fort Bliss, TX 79916

Commander, U.S. Army Strateglc

Communications Command

ATTN: Techntcal Library

Fore Huachuca, Arizona 85613
Commander, U.S. Army Strateglc Communications Command

Safeguard Commications hgency

ATTN: Rlaus Drnat

Fort Huachuca, Arizona 85613

Commander, U.S. Army Armament

Command, Rock Island Arsenal

ATTN: Trebntcal Library

Rock Island, I111nois 61201

Chief of Naval Operations,

Department of the Navy

ATTN: OP-985F

Washington, D.C. 20350

Chlef of Naval Research

Department of the Navy

ATTN: Technical Library

Arlington, Virginla 22217

Offtcer in Charge

Civil Engineering Laboralury

Naval Construction Batealion Center

ATTN: Technical Ltbrary

Port Hueneme, California 93043

offlcer in Charge,

Civil. Engineering Laboratory

Naval Construction Battaition Center

ATTN: Mr. R. J. Odello

Port Hueneme, Californta 93043

Conmender, Naval Electrontcs

Systems Command, Heacquarters

ATTN: PME-117-21A

Washington, D.C. 23360

Commander, Naval racillties

Engineering Command

ATTN: Technical Library, Code 0911C

Hoffman Building

200 Stovall street,

Alexandria, Virginta 2233 ?

crperintendent,

U.S. Naval Postgraduate School

ATTN: Library, Code 2124

Monterey, Californta 93940 
Director,

Naval Research Laboratory

ATTN : Library, Code 2029

Washington, D,C. 20375

Commander, Nava1 Ship Research and Development Center

Underwater Explosive Research Division

ATTN: Technical Librarian

Portsmouth, Virgiria 23709

Commander, Navai Surface Weapons Cencer, Dahlgren Laboratory

ATTN: Technical Ljbrary

Dahlgren, Virginta 22448

Cormander, Naval Surface Weapons Center, White Oak, ATTN: Technical Library, Code 730 Silver Spring, Maryland 20910

Commander, Naval Surface Weapons Center, White Oak, ATIN: Code 1224 Navy Nuc Prgms off Sllver Spring, Maryland 20910

Commancier,

Naval Weapons Center

ATTN: Code 533, Technical Library

China Lake, California 93555

Commander, Naval Weapons

Evaluation Factlity

AT1N: Technical Library

Kirtland AFB

Albuquerque, New Mexico 87117

Commander, Weapons

Evaluation Facility,

A'ITN: R. Hughes

Kirtland AFB

Albuyuerque, New Mexico 87117

Director, Strategic Systems

Project Office

ATTN: NSP-43, Technical Library

Navy Department

Washington, D.C. 20376

Alr Force Armament and Testing

Laboratory, AFSC

ATTN: Technlcal Library

Eglin AFB, Florida $32^{r}+2$
Air Force Cambridge Research

Laboratories, AFSC

ATTN: LWW, Ker P. Thompson

Hanscom Field,

Bedford Massachusetts 01730

Air Force Cambridge Researsh

Laboratories, AFSC

ATTN: SUOL AFCRL, Research LIbrary

L. G. Hanscom Field

Bedford, Massachusette 01730

Air Force Institute of Technology

ATTN: Technical Library

AFI' Building 640, Area B

Wright-Patierson AFs, Chio 45433

Commander, Air Force Weapons Laboratory, AFSC

ATTN: SUL, Technical L. brary

Kirtland AFB, New Mexico 87117

Commander, Air Force Weapons Laboratory, AFSC

ATTN: DEV-S/Dr. M. A. Plamondon

Kirtland AFB, New Mexico 87117

Commander, Air Force Weapons

Laboratory, AFSC

ATTN: DEV-F/Mr. J, L, Bratton

Kirtland AFB, New Mexico 87117

Commander, Air Force Weapons

Laboratory, AFSC

ATTN: DEV-G/Mr. R. W. Henny

Kirtland AFB, New Mexico 87317

Commander, Air Force Weapons

Laboratory, AFSC

ATTN: DEV, Mr. R, J. Port

Kirtland AFB, New Mexico 87117

Headquarters,

Air Force Systems Command

ATTN: Technical Library

Andrews $A F B$,

Washington, D.C. 20331

Commander,

Armament Development \& Test Center

ATTN: Technical Library

Eglin AFB, Florida 32542 
Commander,

Foreign Technology Diviston, AFSC

ATTN: TD-BTA Library

Wright-Patterson AFB, Ohlo 45433

Commander

Rorae Air Development. Center, AFSC

ATTN: EMîLD, Documents Library

Griffiss AFB, New York 13440

Space and Missile Systems

Organization

ATTN: MM/Hard Rock silo Department

Norton $A F B$, Californi, 92409

Space and Missile Systems

Organization,

ATTN: MM:/Engineering Division

Norton AFB, California 92409

Commander,

Strategic Air Command

ATTN : NRI-STINFO LIbrary

Offutt AEB, Nebraska 68113

Los Alamos Scientific Laboratory

ATTN: Document Control for Reports Library

P.0. Box 1663

Los Alamos, New Mexico 87544

Sandia Laboratories,

Livermore Laboratory

ATIN: Document Control for Technical Library

P.O. Box 969

Livermore, Califormia 94550

Sandia Laboratories

ATTN : Document Control for $\mathrm{Mr}, \mathrm{L}, \mathrm{J}$. Vortman

P.0. Box 5800

Albuquerque, New Mexico 87115

Sand ia Laboratories

ATTN: Document Control for 3141 Sandia Rpt Coll

P.0. Box 5800

Albuquerque, New Mexico 87115
U.S. Energy Research \& Development Administration Albuquerque Operations Office ATTN: Document Control for Technical Library

P.0. Box 5400

Albuquerque, New Mexico 87115

U. S. Energy Research \& Development Administration.

Nevada Operations Office

ATTN: Document Control for

P.C. Box 14100 Technical Library

Las Vegas, Nevada 89114

U. S. Energy Research \& Devej,opmant Administration Division of Headquarters Services Lj.brary Branch G-043 ATTN: Doc Control for Class. Tech Lib Warhington, D.C. 20545

Aerespace Corporation ATTN: Dr. Prem N. Fathur P.0. Box 92957

Los Angeles: California 90009

Aerospace Corporation ATTN: Technica1 Information Services P.O. Box 92957

Los Angeles, California 90009

Agbabian Associates ATTN: DI. M. S. Agbabian 250 North Nash Street

El Segundo, California 90245

Applied Theory, incorporated ATTN: Dr. Jchn G. Trulio 1010 Westwood Boulevard Los Angeles, California 90024

Be11 Telephone Laboratories, Inc. ATTN: Technical Report Center Mountain Avenue

Murray H.Lll, New Jersey 07974

Boefig Company Aerospace Group

Missile and Information Systems

Division

ATTN: Mr. R. H、Carlson

P.0. Box 3707

Seattle, Washington 98124 
Braddock, Dunn, \& McDonald, Inc. ATTN: A. Lavagnino

1920 Aline Ave.

Vienna, Virginia 22180

Bradilock, Dunn, \& McDonald, Inc.

ATTN: Mr. Richard Hensley

P.O. Box 9274

Albuquerque International

Albuquerque, New Mexico 87119

California Research \& Technology, Inc. ATTN: Technical Library

6269 Variel Ave,

Woodland H1ls, California 91364

California Research \& Technology, Inc. ATTN: Dr. K. N. Kreyenhagen

6269 Varlel Ave.

Woodiand Hills, California 91364

General American Transportation Corp. General American Research Division ATTN: Dr. G. L. Neidhardt

7449 N. Natchez Ave.

Niles, Illinots 60648

General Electric Company

TEMPO-Center for Advanced Studies

ATTN: DASIAC

816 State Street

Santa Barbara, Californda 93102

I.IT Research Inst1tute

ATTN: Technical Library

10 West 35th Street

Chicago, Illinois 60616

Institute for Defense Analyses

ATTN: IDA Librarian Ruth S, Snith

400 Army-Navy Drive

Arlington, Virginia 22202

Consulting \& Special Engineering

Services, Inc.

ATiN: Dr. J. L. Merritt

P. 0. Box 1206

Redlands, Cal1fornia 92373

Consulting \& Spectal Engineering

Services, Inc.

ATTN: Technical Library

P. 0. Box 1206

Redland6, Caltfornia 92373
Kaman Avidyne

Division of Kaman Sclences Corp. ATTN: Technical LLbrary

83 Second Avenue, Northwest Industrial Park

Burlington, Massachusetrs 01803

Kaman Avldyne

Division of Kam.an Sclences Corp.

ATTN: E. S. Crisicone

83 Jecond Avenue

Nortinwest Industrlal Park

Burlington, Massachusetts 01803

Kaman Avidyne

Division of Kaman Sciences Corp. ATTN: N. P. liobbs

83 Second Avenue,

Northwest industrial Park

Burllngton, Massachusetts 01803

Raman Sciences Corporation

ATTH: Gunning Butler, Jr.

P.D. Box 7463

Colorado Springs, Colorado 80933

Kaman Sciences Corporation

ATTN: Technical Library

P.0. Box 7463

Colorado Sl,rings, Colorado 80933

Lockheed Missiles and Space

Conpany, Inc.

ATT:F: Technical Library

P. O. Boy 504

Sunnyvale, California 94088

Martin Marietta Aerospace,

orlando Diviston

ATTN: Gerbert E. McQuaig - MP 81

P.O. Box 5837

Orlando, Florida 32805

University of Illinois

AT'N: Dr. Nathan $M$. Newmark

1211 Givil Engineering Building

Urbana, Illinois 61801

Physics International Company

ATTN: Technical Library

2700 Merced Street

San Leandro, California 94577 
Physics International Company

ATTN: Doc Control for Mr. Fred M. Sauer

2700 Merced Street

San Leandro, California 94577

Physics International Company

ATTN: Doc Control for

Mr. Dennis L. Orphal

2700 Merced Street

San Leandro, Calffornia 94577

Physics International Company

ATTN: Doc Control for

Dr. Charles Godfrey

2700 Merced Street

San Leandro, Calffornia 94577

Physics International Company

ATTN: Doc Control for

Dr. Robert Swift

2700 Merced Street

San Leandro, California 94577

Physics International Company

ATTN: Doc control for

Mr. Larry Behrman

2700 Merced Street

San Leandro, California 94577

RGD Assoclates

ATTN: Technical Library

P.O. Box 9695

Marina Del Ray, Californta 90291

R\&D Assoctaces

ATTN: Dr. H. F. Cooper, Jr.

P.O. Box 9695

Marina Del Ray, Californla 90291

R\&D Assoclates

ATTN: Dr. Harold $L$, Hrode

P.O. Box 9695

Marina De1 Ray, California 90291

R\&D Associates

ATTN: Mr. WIlliam B. Wright

P.0. Box 9695

Marina Del Ray, California 90291

RED Associates

ATTN: Dr. C. P. Knowles

P.O. Box 9695

Marina Del Ray, Californta 90291
RGD Associates

ATTN: Mr. J, G. Lewis

P.O. Box 9695

Marina Del Ray, Callfornia 90291

Science Appl1cations, Inc. ATTN: Dr. W. M. Layson 191 I North Fort Myer Drive Suite B0B,

Arlington, Virginia 2220y

Sclence Applications, Ipc. ATTN: Techntcal Library

P.0. Box 2351

La Jolla, California 92037

Sclence Applications, Inc. ATTN: R. A. Shunk

P.0. Box 3507

Albuquerque, New Mextco 87110

Southwest Research Institute

ATTN; Mr. A. B. Henzel

V.0. Drawer 28510

San Antonio, Texas 78284

Stanford Research Instltute

ATTN: SRI LIbrary Room G021

333 Ravenswood Ave.

Menlo Park, California 94025

Stanford Research Institute

ATTN: DF, G. Abrahamson

333 Ravenswood Ave.,

Menlo Park, California 94025

Science Appltcations, Inc.

ATTN: Dr. D. Hall

P.O. Box 34

Pleasanton, CA 94566

Science Applications, Inc.

ATTN: Mr. J. Dishon

P.O. Box 34

Pleasanton, CA 94566

Systems, Sclence and Software ATTN: Dr. Donald R. Grine P.0. Box 1620

La Jolla, California 92037 
Systems, Science and Software

ATTN: Dr. T. D. Riney

P.O. Box 1620

La Jolla, California 92037

Systems, Science and Software

ATTN: Technical Libraty

P.O. Box 1620

La Jolla, Californta 92037

Systems, Sclence and Software

ATTN: Dr. T. Blake

P.0. Box 1620

La Jolla, Calffornia 92037

Systems, Sclence and Software

Washington Research Center

ATTN: Jack Cane

111 South Fairfax St.

Alexandrla, Virginia 22314

Teledyne Brown Engineering Company, Inc.

ATTN: Dr. M. C. Patel

Cummings Research Park,

Hunts ville, Albama 35807

Terra Tek, Inc.

ATTN: Mr. S. J. Green

University Research Park,

420 Wakara Way

SaIt Lake C1ty, Utah 84108

TRW Systems Group

ATTN: Greg Hulcher

San Bernardino Operations

P.D. Box 1310

San Bernardino, California 92402

TRW Defense and Space Systems Group

ATTN: Technical Information Cencer/ s-1930

One Space Park

Bullding $\mathrm{Rl} / 2170$

Redondo Beach, California 90278

TRW Defense and Space Systems Group

ATTN: Dr. J. J. Ferrell

One Space Park

Bullding R. $/ 2170$

Redondo Beach, California 90278
Heldlinger Associates

Consulting Engineers

ATTN: Dr. Melvin L. Baron

110 East 59th Street

New York, Wew York 10022

Weidlinger Associates,

Consuiting Engineers

ATTN: Dr. J. Isenberg

2710 Sand Hill Road, Suice 230

Menlo Park, California 99025

Distribution Category UC-11

WC/nus/mla 